\title{
5. SITE 385: VOLCANISM AT VOGEL SEAMOUNT IN THE CENTRAL NEW ENGLAND SEAMOUNT CHAIN
}

\author{
The Shipboard Scientific Party ${ }^{1}$
}

\section{SITE DATA}

Position: $37^{\circ} 22.17^{\prime} \mathrm{N}, 60^{\circ} 09.45^{\prime} \mathrm{W}$

Water Depth (PDR, sea level): 4936 meters

Water Depth (PDR, rig floor): 4946 meters

Bottom Felt at (rig floor): 4966 meters

Penetration: 392.9 meters

Number of Holes: 1

Number of Cores: 24

Total Length Cored: 227.6 meters

Total Core Recovered: 63.43 meters

Core Recovery: $27.9 \%$

Oldest Sediment Cored: Volcaniclastic breccia Bottoms at: 392.9 meters

Age: Lower Maestrichtian or older

Velocity: $3.61-3.68 \mathrm{~km} / \mathrm{sec}$

Nature of "Basement': Volcaniclastic breccia Encountered at: 337.8 meters

Velocity: $3.61-3.68 \mathrm{~km} / \mathrm{sec}$

Date Occupied: $0620 \mathrm{Z}$ hours, 18 July 1975

Date Departed: 2210Z hours, 20 July 1975

Time on Site: 2 days, 15 hours, 50 minutes

Principal Results: Site 385 was drilled $\mathbf{3 9 2 . 9}$ meters through an acoustically non-laminated sediment layer, through Horizon $A^{c}$, and into the underlying volcaniclastic apron forming the north flank of Vogel Seamount. Horizon $A^{c}$ can be traced from beneath the Sohm Abyssal Plain to the drill

${ }^{1}$ Brian E. Tucholke (Co-Chief Scientist), Lamont-Doherty Geological Observatory, Palisades, New York; Peter R. Vogt (CoChief Scientist), Naval Research Laboratory, Washington, D.C.; Kenneth R. Demars, University of Rhode Island, Kingston, Rhode Island (now at: University of Delaware, Newark, Delaware); Jon S. Galehouse, San Francisco State University, San Francisco, California; Robert L. Houghton, Woods Hole Oceanographic Institution, Woods Hole, Massachusetts (now at: University of Alberta, Edmonton, Alberta, Canada); Ansis Kaneps, Deep Sea Drilling Project, Scripps Institution of Oceanography, La Jolla, California; John W. Kendrick, Shell Development Company, Houston, Texas; I. N. McCave, University of East Anglia, Norwich, England; Charles L. McNulty, University of Texas, Arlington, Texas; Ivar O. Murdmaa, P. P. Shirshov Institute of Oceanology, Moscow, USSR; Hisatake Okada, Lamont-Doherty Geological Observatory, Palisades, New York (now at: Yamagata University, Yamagata, Japan); and Peter Rothe, Mineralogisch Petrografisches Institut der Universität Heidelberg, Heidelberg, Federal Republic of Germany (now at: Geographisches Institut der Universität Mannheim, Mannheim, Federal Republic of Germany). site, where it occurs $0.2 \mathrm{sec}$ sub-bottom and $0.17 \mathrm{sec}$ above the volcaniclastic apron. A total of 24 cores $(227.6 \mathrm{~m})$ was taken; the low overall recovery $(63.4 \mathrm{~m})$ reflects poor coring performance in cherts and uncemented volcaniclastic sands and gravels.

Formations encountered are as follows: A discontinuously cored section of Pleistocene to upper Oligocene clays $(0-138 \mathrm{~m})$ overlies continuously cored upper lower Eocene clays and chert (138-165 m sub-bottom) containing a rich and well-preserved radiolarian fauna. Horizon $A^{c}$ correlates with an alternating chert and radiolarian ooze interval approximately $153-165$ meters sub-bottom. The section from 165 to 206 meters consists of zeolitic silty clay containing poorly preserved and unidentified radiolarian assemblages. Lowermost Danian to middle Maestrichtian marly ooze $(206-251 \mathrm{~m})$ overlies volcanogenic sediments older than middle Maestrichtian that continue to 393 meters. A thin $(18 \mathrm{~cm})$ layer of aphanitic basalt was cored at 283 meters; this could be either a sill, a flow, or a displaced boulder; however, its young radiometric age $(21 \pm 3$ m.y.) suggests it is a sill intruded during a period of minor volcanic rejuvenation during the early Miocene. The deepest volcanic material penetrated is a volcaniclastic breccia very similar to that recovered at Site 382 at Nashville Seamount.

As at Nashville, breccia was recovered at two levels and episodic volcanism is suggested. The relatively inactive period is nevertheless represented by volcanogenic sediments, and both episodes of breccia emplacement probably occurred within a few million years or less. Basalt fragments extracted from the breccia are highly alkalic, vesicular, and relatively enriched in light rare earths. The fragments were derived from various eruptive events, at least some of which occurred at depth of less than 0.5 to 1 $\mathrm{km}$ below sea level.

Unfortunately, the volcanic unit is unfossiliferous except for a few long-ranging benthic foraminifers of possible. Coniacian-Santonian age, and the deepest reliable dates in the hole are for the Maestrichtian marly ooze above the unit. However, the two most reliable radiometric dates on the lower breccia ( $82.1 \pm 8$ and $91.2 \pm 3 \mathrm{~m} . \mathrm{y}$.$) , in combination$ with other data, suggest the main constructional volcanism on Vogel Seamount may have occurred about 87 to 92 m.y.B.P. Although this makes Vogel Seamount slightly older than Nashville and would be consistent with plate motion over a stationary hot spot at $\sim 4 \mathrm{~cm} / \mathrm{yr}$, the age difference may not be significant. Thus, simultaneous volcanism cannot be excluded.

\section{BACKGROUND AND OBJECTIVES}

The overall objectives of drilling along the New England Seamount chain are given in the Site $382 \mathrm{Re}-$ port, and they will not be repeated here. Vogel Sea- 
mount was chosen as an alternate to Gosnold Seamount because of anticipated strong currents at Gosnold and time limitations. Vogel is a relatively conical seamount with a minimum depth of about 1400 meters. The seamount is located about $450 \mathrm{~km}$ northwest of Site 382, which was drilled at the southeastern end of Nashville Seamount (Figure 1); according to the hot-spot hypothesis, Vogel Seamount should be older than Nashville. For reasonable rates of plate motion over a mantle hot spot ( 1 to $10 \mathrm{~cm} / \mathrm{yr}$ ), the age difference would be 45 to $4.5 \mathrm{~m} . \mathrm{y}$;; age differences in this range were considered detectable if fossiliferous strata could be cored above or within volcaniclastic units. In addition to the objectives of dating the volcanic activity at Vogel Seamount and recovering relatively unaltered basaltic material, drilling at Site 385 was intended to establish the post-volcanic sedimentation history at the site. A reference profile collected by Lynch across the southeast flank of Vogel Seamount showed a prominent reflector near basement that could be Horizon $A^{c}$ (Figure 2; see Tucholke, this volume). One of the objectives of Site 385 was to determine the age and lithofacies of this reflector. Total sediment thickness above the acoustically opaque seamount apron in on the order of 0.3 to $0.6 \mathrm{sec}$ reflection time.

\section{OPERATIONS}

Having altered plans from our original goal of drilling at Gosnold Seamount because of strong currents encountered enroute, we changed course for Vogel Seamount at $1230 \mathrm{hr}(1630 \mathrm{Z})$ on $17 \mathrm{July}$. We planned to intercept the Lynch reference profile on the eastern flank of Vogel Seamount (Figures 2,3) near $37^{\circ} 02^{\prime} \mathrm{N}$, $60^{\circ} 00^{\prime} \mathrm{W}$ (Lynch 71, $2200 \mathrm{hr}, 28$ August 1971). In that area an acoustically non-laminated sediment layer about $0.5 \mathrm{sec}$ thick overlies the volcaniclastic apron of the seamount. Approximately $0.1 \mathrm{sec}$ or less above acoustic basement, a prominent reflector (Horizon $A^{C}$ ?) is locally present; our aim was to core and confirm the lithofacies of this reflector while drilling to the volcaniclastic horizon. Enroute to the Lynch 71 track, we crossed the northern flank of Vogel Seamount, where good seismic data showed a probable Horizon $A^{c}$, a buried volcaniclastic apron, and possibly the original oceanic basement at more than $1 \mathrm{sec}$ sub-bottom (Figures 3, 4). As the base of the seamount was approached the deep oceanic crust became masked by the volcaniclastic apron. After crossing to the southeast flank of Vogel Seamount, we found no ambiguous Horizon $A^{C}$ near our intersection with the Lynch 71 profile, and we therefore changed course to $315^{\circ}$ at $2322 \mathrm{hr}(0322 \mathrm{Z})$ in order to drill Site 385 along the Challenger profile across the northern flank of the seamount. At $0217 \mathrm{hr}$ on $18 \mathrm{July}$ we slowed to 6 knots, and a pre-soaked beacon was dropped at 0220 (0620Z).

The location of Site 385 , determined by averaging satellite fixes 581 through 603 , is $37^{\circ} 22.17^{\prime} \mathrm{N}$, $60^{\circ} 09.45^{\prime} \mathrm{W}$ (Figure 1). The driller felt bottom at 4966 meters, measured from the derrick floor, or 4956 meters below sea level. The PDR value, corrected to sea level in Matthews' area 13, is 4936 meters. Part of the 20-meter discrepancy might be explained if the bit penetrated some soft sediment before bottom was "felt." However, Site 385 is located on the steep $\left(5^{\circ}\right)$ lower flank of the seamount, and simple calculations show that apparent (PDR) bottom is about 19 meters shallower than true water depth because of side echoes. Because there was little current at the site and the drill pipe appeared to be hanging vertically, we accepted the driller's depth as the best estimate of true water depth.

The coring strategy was to core discontinuously to a level just above the mid-sediment reflector, and then to core continuously down into the volcaniclastic basement. The first core was brought aboard at $1524 \mathrm{hr}$ on 18 July from a sub-bottom depth of 22.3 to $31.8 \mathrm{~m}$ (Table 1).

Continuous coring began at 136.5 meters sub-bottom (Core 4), and the cores contained well-preserved Eocene radiolarian assemblages and clay (Figure 5). Cores 6 and 7 (155.6 to $174.6 \mathrm{~m})$ recovered alternating upper-lower Eocene radiolarian clays and chert beds, thus confirming the mid-sediment reflector as Horizon $A^{c}$. Core recovery was very poor in these two cores $(<0.5 \mathrm{~m}$ total), but the sediment sequence can be reconstructed from drilling rates. We estimate that the chert penetrated by the bit consists of an upper, fairly massive unit several meters thick, located in the lower part of Core 5; Core 6 penetrated five or six discrete hard layers presumed to be stringers or thin beds of chert. Core 7 penetrated no hard layers but recovered chert probably as downhole cavings; no chert was recovered in Core 5. The poor core recovery (mostly of chert) is attributed to chert's tendency to shatter and plug the core catcher. Recovery is also reduced by the need to increase circulation in hard formations, which tends to wash away soft sediment interbedded with the chert.

Cores 7 through 13, below the cherts, recovered a sequence of unfossiliferous zeolitic clays (165.1-203.0 m), as well as chalky claystone and marly ooze (203.0$241.0 \mathrm{~m}$ ) in an unusual lower Danian calcareous sequence. Cores 14 through 16 recovered banded, variegated clays (205.6 to $288.4 \mathrm{~m}$ ). From Sample 16, CC to the bottom of the hole $(392.9 \mathrm{~m})$, cores recovered an assortment of predominately coarse volcaniclastic material including basalt fragments, volcaniclastic breccia, sand, and clay. Of a total thickness of $114.0 \mathrm{~m}$ (Cores 16-24) 85.4 meters were cored but only 12 meters recovered. Core 17 was empty and two others contained only a few pebbles of basalt. A plastic sock was installed in the catcher, but this produced no noticeable improvement. The poor recovery in this volcaniclastic formation is probably due to the presence of uncemented basalt fragments or coarse volcaniclastic sand. This would explain the relatively fast drilling (about $1 \mathrm{~m} / \mathrm{min}$ ) coupled with very poor recovery. Where such zones are cemented into a breccia they are readily cored, but drilling rates are much reduced $(0.1-0.2 \mathrm{~m} / \mathrm{min})$.

It was hoped that age-diagnostic fossiliferous sediment would be recovered as interbeds in the volcaniclastic material. However, compared to Site 382, the volcanogenic sediments at Site 385 were less fossiliferous and below Core 13 (middle Maestrichtian), no biostratigraphic dating was possible. The paucity of mi- 


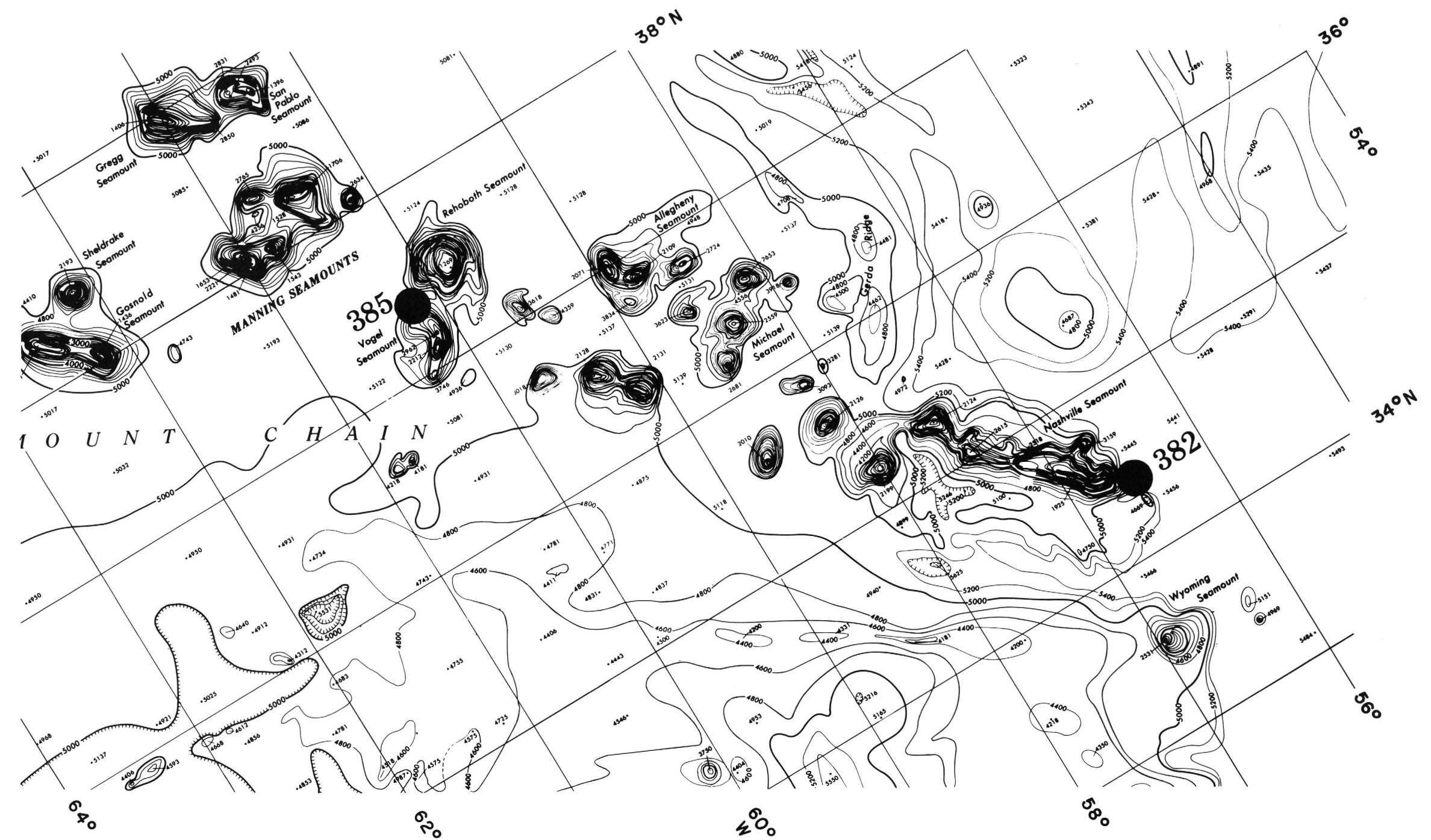

Figure 1. Bathymetry of the southeastern part of the New England seamount chain showing location of Sites 385 and 382. Depths in uncorrected meters. 


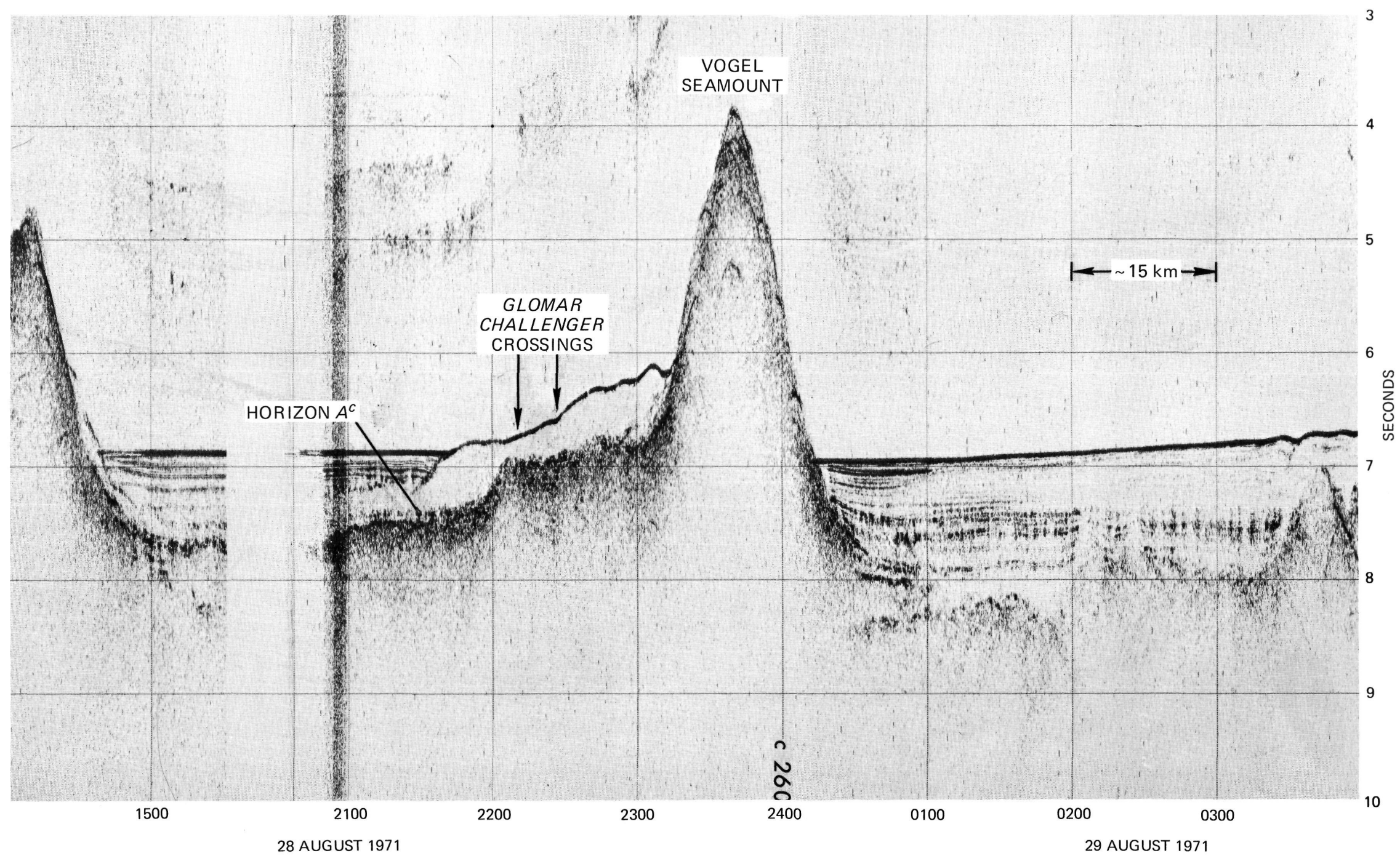

Figure 2. Lynch 71 reference seismic profile across Vogel Seamount. Location of profile is shown in Figure 3. 




Figure 3. Tracks of Glomar Challenger and Lynch 71 in the vicinity of Site 385. Hour ticks are annotated /Challenger times in GMT).

crofossils may be explained by deposition below the $\mathrm{CCD}$, dilution of the calcareous fraction by volcaniclastics, or loss of pelagic sediment washed out by strong circulation in the process of drilling through coarse, volcaniclastic material. Drilling results are summarized in Figure 5.

Drilling further from the seamount might have improved the core recovery and increased the likelihood of completely penetrating the volcanogenic horizons and thus dating the onset of volcanism. At Site 385 (as at Site 382) slow drilling in the breccia, coupled with time constraints, prevented penetration of the volcaniclastic zone.

Core $24(383.5$ to $392.9 \mathrm{~m})$ was recovered at $0904 \mathrm{hr}$ on 20 July and the drill string was pulled. On this morning a salt-water leak was discovered in the gear-box of the No. 2 (port) bow thruster. After drifting west off the beacon 1810 to $1910 \mathrm{hr}(2210 \mathrm{Z}-2310 \mathrm{Z})$ while testing the bow thruster, we were underway on a course of $209^{\circ}$ PGC for Site 386 (Figure 3). The next day Global Marine requested that we change course for Bermuda to have the bow thruster repaired.

\section{LITHOLOGY}

Site 385 was drilled 392.9 meters through an acoustically transparent sediment sequence and into the volcaniclastic apron on the north flank of Vogel Seamount. On the basis of a 16.1 per cent recovery of the depth drilled, the sedimentary sequence is divided into three main lithofacies (see Table 2). Lithofacies thick- nesses are subject to some uncertainty because of intermittent coring and poor recovery. Downhole changes in composition determined from examination of smear slides are given in Foldout IV in the cover pocket of this volume.

\section{Unit 1 - Hemipelagic Clay (0-137.6 m)}

Unit 1 (Core 1 to Core 4, Section $1,111 \mathrm{~cm}$ ) is overlain by at least 0.15 meter of soupy, homogeneous, brown nanofossil-foraminifer ooze of Holocene age in Core 1. The exact relationship of this calcareous ooze to the underlying olive-gray hemipelagic clay is uncertain, but it was probably punch-cored while "feeling" for bottom without circulation and therefore is of uncertain thickness. Its average composition as determined by smear slides and X-ray diffraction (XRD) analysis is:

$\begin{array}{lr}\text { Foraminifers } & 25 \% \\ \text { Clay } & 25 \% \\ \text { Unspecified carbonate } & 20 \% \\ \text { Nannofossils } & 15 \% \\ \text { Quartz } & 8 \% \\ \text { Feldspar } & 5 \% \\ \text { Mica } & 1 \% \\ \text { Iron-manganese oxides } & 1 \%\end{array}$

A 3-cm iron-manganese oxide nodule was found embedded in the Holocene ooze. The nodule core is of quartz grains and contains a single lower upper Miocene Discoaster neorectus nannofossil that suggests an oxide deposition rate of $\sim 3 \mathrm{~mm} / 10^{6} \mathrm{yr}$; this compares favorably with the rate determined for encrustations on coral along the New England seamounts (J. G. Moore, personal communication, 1975).

The hemipelagic section is composed of firm but plastic homogeneous clay, olive and light olive-gray in color. Unit 1 was intermittently cored so that it is difficult to determine accumulation rates, but slow rates or undetected hiatuses must occur within the section (see Figure 12). The upper part of Unit 1 is intensely disturbed by coring, and mottles, burrows, and contacts are stretched out vertically for several centimeters. A 3 -cm highly fractured iron-manganese oxide nodule found embedded in the clay in Core 1 at 23.51-23.54 meters sub-bottom depth is very similar to the nodule discovered in the overlying nannofossil foraminifer ooze, and it may be downhole contamination. Unit 1 has a slightly convex basal contact that is relatively undisturbed; it is at the base of $6 \mathrm{~cm}$ of firm, moderately dark greenish gray clay in Core 4, Section 1, 105-111 cm.

Except for a few gradational color changes, Unit 1 is grossly homogeneous. However, mottles and burrows commonly are composed of palagonitic or glauconiterich $(7-10 \%)$ silty clay. The glauconite is of clay size. Glauconite can potentially form in weakly reducing to weakly oxidizing hemipelagic sediments by the reaction:

$$
\text { clay mineral }+ \text { quartz }+\mathrm{K}^{+}=\text {glauconite }
$$

(Dapples, 1967). Because the quartz content of the glauconitic mottles appears to be slightly lower than that of the surrounding sediment, this process may be active. Alternatively, the diffuse clots of glauconite could represent a stage in the diagenetic alteration of detrital 


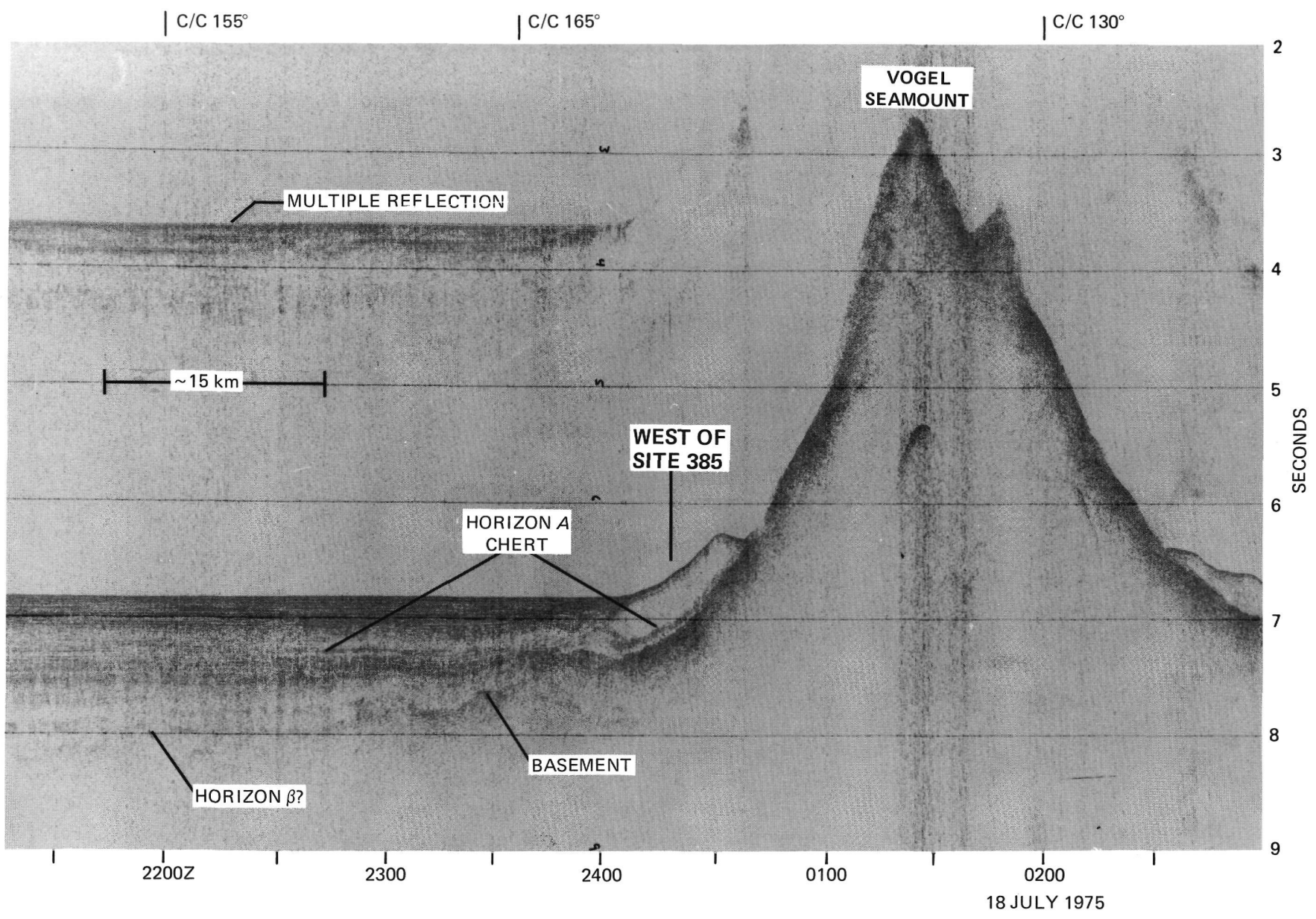

Figure 4. Glomar Challenger profiler record near Site 385. Location is given in Figure 3.

glauconite to chlorite. The frequency of glauconitic burrows and the degree of glauconite enrichment diminishes with depth in the unit.

The average composition for Unit 1 as determined from smear slides and XRD is:

\begin{tabular}{lr} 
Clay & $65 \%$ \\
Quartz & $20 \%$ \\
Feldspar & $10 \%$ \\
Radiolarians & $3 \%$ \\
Glauconite & $1 \%$ \\
Mica, heavy minerals, zeolites, and \\
\multicolumn{2}{c}{ plant debris are important in trace } \\
amounts
\end{tabular}

Total carbonate ranges from 0 to 4 per cent, and averages 1 per cent.

Unit 1 is interpreted as hemipelagic clay that accumulated below the calcite compensation depth (CCD). Obvious terrigenous debris includes quartz and plant detritus. The differential accumulation of this unit around Vogel Seamount (Figure 4) suggests deposition controlled at least in part by bottom currents. This unit is the lithologic equivalent of the Unit 2 hemipelagic clays at Nashville Seamount (Site 382). Very low sedimentation rates $(<1.6 \mathrm{~m} / \mathrm{m}$.y.) or hiatuses characterize the Miocene to Pliocene and middle Eocene-upper Oligocene parts of Unit 1 (see Figure 12).

\section{Unit 2 - Pelagic Clay and Ooze (137.6 to 250.6 m)}

Disconformably underlying the hemipelagic clays of Unit 1 is a sequence of pelagic clays and oozes here distinguished as Unit 2. The disconformity lies in Section 1 of Core 4 at $111 \mathrm{~cm}$. Sediments above the disconformity are still in the upper Oligocene Lychnocarioma elongata radiolarian zone, while those below belong in the upper lower Eocene Theocotyle cryptocephala cryptocephala radiolarian zone. thus, a hiatus of some 25 m.y. separates the two units. Except for an interval of 11.6 meters near the base, the sediments of Unit 2 were continuously cored. However, poor recovery, averaging 23 per cent (ranging from 0.5 to $61 \%$ ), complicates interpretation of the unit. Unit 2 was divided into three subunits (Table 2). We believe this whole unit to be pelagic because of (1) an absence of terrigenous clastics, (2) a dominance of authigenic minerals in the crystalline fraction, (3) abundant pelagic microfossils, and (4) the presence of slowly forming phases such as iron-manganese oxides.

\section{Sub-Unit 2A - Radiolarian Clay and Ooze (137.6-165.1 m)}

Sub-unit 2A consists of firm, sub-plastic, very thin to medium beds of grayish yellow-green changing downward to thicker beds of alternating very pale brown and 
TABLE 1

Coring Summary, Site 385

\begin{tabular}{|c|c|c|c|c|c|c|c|c|c|c|}
\hline \multirow{2}{*}{$\frac{\text { Core }}{1}$} & \multirow{2}{*}{$\begin{array}{c}\begin{array}{c}\text { Time } \\
\text { (Day-Hours) }\end{array} \\
18-1524\end{array}$} & \multicolumn{2}{|c|}{ Total Deptha } & \multicolumn{2}{|c|}{$\begin{array}{l}\text { Sub-Bottom } \\
\text { Depth }\end{array}$} & \multirow{2}{*}{$\begin{array}{r}\text { Cored } \\
9.5\end{array}$} & \multirow{2}{*}{$\frac{\text { Recovered }}{5.20}$} & \multirow{2}{*}{$\%$} & \multirow[t]{2}{*}{ Lithology } & \multirow{2}{*}{$\frac{\text { Age }^{\mathrm{b}}}{\text { Pleist. }}$} \\
\hline & & 4988.3 & 4997.8 & 22.3 & 31.8 & & & & & \\
\hline 2 & $18-1655$ & 5026.4 & 5036.0 & 60.4 & 70.0 & 9.6 & 9.45 & 98 & Clay & $\mathrm{U}$ Olig \\
\hline 3 & $18-1840$ & 5064.5 & 5074.0 & 98.5 & 108.0 & 9.5 & 9.45 & 99 & Clay & U. Olig. \\
\hline 4 & $18-2003$ & 5102.5 & 5112.1 & 136.5 & 146.1 & 9.6 & 3.50 & 36 & Rad clay and ooze & M. Eoc. \\
\hline 5 & $18-2125$ & 5112.1 & 5121.6 & 146.1 & 155.6 & 9.5 & 5.17 & 54 & Rad clay and ooze & L. Eoc. \\
\hline 6 & $18-2243$ & 5121.6 & 5131.1 & 155.6 & 165.1 & 9.5 & 0.05 & 1 & Rad clay; chert & L. Eoc. \\
\hline 7 & $18-2359$ & 5131.1 & 5140.6 & 165.1 & 174.6 & 9.5 & 0.10 & 1 & Zeol. clay; chert & $?$ \\
\hline 8 & $19-0148$ & 5140.6 & 5150.1 & 174.6 & 184.1 & 9.5 & 1.35 & 14 & Zeol. clay & ? \\
\hline 9 & $19-0355$ & 5150.1 & 5159.4 & 184.1 & 193.4 & 9.3 & 0.75 & 8 & Zeol. clayey silt & ? \\
\hline 10 & $19-0530$ & 5159.4 & 5169.0 & 193.4 & 203.0 & 9.5 & 0.42 & 4 & Zeol. clay; claystone & ? \\
\hline 11 & $19-0700$ & 5169.0 & 5178.5 & 203.0 & 212.5 & 9.5 & 2.30 & 24 & Zeol. clay; marly ooze & L. Paleo. \\
\hline 12 & $19-0843$ & 5178.5 & 5188.0 & 212.5 & 222.0 & 9.5 & 2.15 & 23 & Clay; marly nanno ooze & U. Maes. \\
\hline 13 & $19-1044$ & 5197.6 & 5207.0 & 231.6 & 241.0 & 9.4 & 5.75 & 61 & $\begin{array}{l}\text { Calcareous clay; } \\
\text { marly nanno ooze }\end{array}$ & M. \& U. Maes. \\
\hline 14 & $19-1256$ & 5216.6 & 5226.1 & 250.6 & 260.1 & 9.5 & 4.55 & 48 & Vitric silty clay & $?$ \\
\hline 15 & $19-1457$ & 5235.6 & 5244.9 & 269.6 & 278.9 & 9.3 & 1.24 & 13 & Vitric silty clay; clay & $\dot{?}$ \\
\hline 16 & $19-1636$ & 5244.9 & 5254.4 & 278.9 & 288.4 & 9.5 & 3.35 & 35 & Clay; silt; sand; basalt & $?$ \\
\hline 17 & $19-1758$ & 5254.4 & 5263.9 & 288.4 & 297.9 & 9.5 & 0 & 0 & & $?$ \\
\hline 18 & $19-1940$ & 5263.9 & 5273.4 & 297.9 & 307.4 & 9.5 & 0.15 & 2 & Basalt; volc. breccia & $?$ \\
\hline 19 & $19-2125$ & 5273.4 & 5282.9 & 307.4 & 316.9 & 9.5 & 0.35 & 4 & Basalt; sand; clayey silt & $?$ \\
\hline 20 & $20-0043$ & 5302.0 & 5311.5 & 336.0 & 345.5 & 9.5 & 2.41 & 26 & Volc. breccia; sand & $?$ \\
\hline 21 & $20-0240$ & 5311.5 & 5321.0 & 345.5 & 355.0 & 9.5 & 0.04 & 1 & Volc. breccia & $?$ \\
\hline 22 & $20-0410$ & 5321.0 & 5330.5 & 355.0 & 364.5 & 9.5 & 0.02 & 1 & Basalt; clayst. & $?$ \\
\hline 23 & $20-0620$ & 5340.0 & 5349.5 & 374.0 & 383.5 & 9.5 & 4.08 & 43 & Volc. breccia & $?$ \\
\hline 24 & $20-0904$ & 5349.5 & 5358.9 & 383.5 & 392.9 & 9.4 & 1.60 & 17 & Volc. breccia & $?$ \\
\hline \multirow{2}{*}{\multicolumn{4}{|c|}{ Total }} & \multirow{2}{*}{\multicolumn{2}{|c|}{$\begin{array}{l}\text { Total cored } \\
\text { Total recovered }\end{array}$}} & 227.6 & & & & \\
\hline & & & & & & & 63.43 & & & \\
\hline \multirow{3}{*}{\multicolumn{3}{|c|}{$\begin{array}{l}\% \text { recovery in intervals cored } \\
\% \text { recovery of depth drilled } \\
\% \text { of depth drilled which was cored }\end{array}$}} & $=27.9 \%$ & & & & & & & \\
\hline & & & $=16.1 \%$ & & & & & & & \\
\hline & & & $=57.9 \%$ & & & & & & & \\
\hline
\end{tabular}

aFrom rig floor, 10 meters above sea level.

bU $=$ upper, $\mathrm{L}=$ lower.

light gray radiolarian clay and ooze. The lighter beds are generally richer in siliceous fossils. Pink mottles tend to be enriched in diatoms as well as radiolarians.

A fragment of weathered basalt $1 \mathrm{~cm}$ in diameter was recovered in Section 3 of Core 4 at $129 \mathrm{~cm}$, and it is believed to be derived from Vogel Seamount. A few fragments of chert recovered in the core catchers of Cores 6 and 7 represent a zone of alternating chert and radiolarian ooze that correlates with Horizon $A^{c}$. Drilling rates suggest the cherts occur at the level of Cores 5 and $6(153-165 \mathrm{~m})$ and that the chert in Core 7 is probably downhole contamination. Brecciation of the chert by drilling and consequent blocking of the core barrel may account for the poor recovery in Cores 5 through 7 .

The average composition of Sub-unit $2 \mathrm{~A}$ as determined from smear slides and XRD is:

\begin{tabular}{lr} 
Clay & $60 \%$ \\
Radiolarins & $27 \%$ \\
Diatoms & $5 \%$ \\
Quartz & $5 \%$ \\
Feldspar & $3 \%$ \\
Palagonite, silicoflagellates, glaucon- \\
\multicolumn{2}{l}{ ite, and mica are important } \\
\multicolumn{2}{c}{ components. }
\end{tabular}

Carbonate content is mostly nil, with one measured value of 2 per cent.

\section{Sub-Unit 2B - Zeolitic Silty Clay (165.1-205.8 m)}

The nature of the contact between this sub-unit and Sub-unit $2 \mathrm{~A}$ is uncertain because of poor core recovery. The top of the unit is thought to correlate with the contact against the cherts of Horizon $A^{C}$. The lower contact of Sub-unit 2B is gradational with the underlying marly ooze and is strongly mottled.

Sub-unit 2B (Core 7 through Core 11, Section 2, 125 $\mathrm{cm}$ ) consists of yellowish brown to grayish brown zeolitic silty clays. In Sample 7, CC, the silty clay of a 9-cm black bed contains about 30 per cent iron-manganese oxides. Cores 9 and 10 contain alternating beds of hard claystone and soft, unconsolidated silty clay. This sequence of thin lithified beds may help account for the poor recovery in these cores $(8 \%$ and $4.5 \%$, respectively). Mottling is variable throughout.

Accumulation rates for Sub-unit 2B are uncertain because of poor biostratigraphic control. Only an average rate for the whole sub-unit can be determined; on the basis of the upper lower Eocene date in Sub-unit 2A 




Figure 5. Graphic hole summary, Site 385. 
TABLE 2

Lithologic Units at Site 385

\begin{tabular}{|c|c|c|c|c|c|}
\hline Unit & Lithology & Age & $\begin{array}{l}\text { Thickness } \\
\text { (m) }\end{array}$ & $\begin{array}{l}\text { Sub-Bottom Depths } \\
\text { at Base of Unit (m) }\end{array}$ & Core Numbers \\
\hline 1 & $\begin{array}{l}\text { Minor nanno-foram ooze } \\
\text { and hemipelagic clay }\end{array}$ & $\begin{array}{l}\text { Pleistocene to } \\
\text { U. Oligocene }\end{array}$ & $\leqslant 137.6$ & 137.6 & 1 to $4-1,111 \mathrm{~cm}$ \\
\hline $2 \mathrm{~A}$ & Radiolarian clay and ooze & L. Eocene & 27.5 & 165.1 & $4-1,111 \mathrm{~cm}$ to $6, \mathrm{CC}$ \\
\hline $2 \mathrm{~B}$ & Zeolitic silty clay & $\begin{array}{l}\geqslant \text { L. Eocene(?) to } \\
\text { L. Paleocene }\end{array}$ & 40.7 & 205.8 & 7 to $11-2,125 \mathrm{~cm}$ \\
\hline $2 \mathrm{C}$ & $\begin{array}{l}\text { Marly ooze, clay, marly } \\
\text { nannofossil ooze, and } \\
\text { calcareous silty clay }\end{array}$ & $\begin{array}{l}\text { L. Paleocene to } \\
\text { M. Maestrichtian }\end{array}$ & $<44.8$ & $<250.6$ & $11-2,125 \mathrm{~cm}$ to $13, \mathrm{CC}$ \\
\hline $3 \mathrm{~A}$ & Vitric silty clay and clay & $\begin{array}{l}\geqslant \text { Maestrichtian }(?) \\
\quad \text { to } \geqslant \text { Coniacian(?) }\end{array}$ & 32.8 & 283.4 & 14 to $16-3,146 \mathrm{~cm}$ \\
\hline $3 \mathrm{~B}$ & Basalt (? and coarse clastics) & (L. Miocene-sill) & 5.0 & $>283.4$ & $16-3,146 \mathrm{~cm}$ to $16, \mathrm{CC}$ \\
\hline $3 \mathrm{C}$ & Vitric clayey silt & ? & $>0.26$ & $308.9-316.8$ & $19-1$ to $19-1,150 \mathrm{~cm}$ \\
\hline 3D & Basaltic silty sands & ? & $21.0-28.9$ & 337.8 & $19, \mathrm{CC}$ to $20-2,32 \mathrm{~cm}$ \\
\hline $3 \mathrm{E}$ & Volcaniclastic breccia & ? & $>55.1$ & $>392.9$ & $20-2,32 \mathrm{~cm}$ to 24 \\
\hline
\end{tabular}

and the lower Paleocene date for Core 11, the rate is $\sim 3$ $\mathrm{m} / \mathrm{m} . \mathrm{y}$.

The average composition of Sub-unit 2B based on smear slide descriptions and XRD is:

$\begin{array}{lr}\text { Clay } & 63 \% \\ \text { Zeolite } & 15 \% \\ \text { Quartz } & 10 \% \\ \text { Cristobalite and } & \\ \quad \text { disordered opal } & 7 \% \\ \text { Feldspar } & 3 \% \\ \text { Palagonite } & 1 \% \\ \text { Unspecificd carbonate } & 1 \% \\ \text { Glauconite, diatoms, and radiolarians } \\ \quad \text { in trace amounts }\end{array}$

The nature of the zeolites is discussed by Houghton et al. (this volume). Two carbonate bomb determinations gave $\mathrm{CaCO}_{3}$ values of 6 and 1 per cent.

\section{Sub-Unit 2C - Marly Ooze, Clay, Marly Nannofossil Ooze, and Calcareous Silty Clay (205.8-250.6 m)}

Sub-unit 2C (Samples $11-2,125 \mathrm{~cm}$ to $13, \mathrm{CC}$ ) is thinly stratified with alternating beds of firm, light greenish gray and reddish brown marly nannofossil ooze, clay, and silty clay. The contact with overlying Sub-unit $2 \mathrm{~B}$ is intensely mottled and gradational. The top of Core 12 contains a $12-\mathrm{cm}$ bed of gray-brown clay intercalated with greenish gray zeolitic silty clay, similar to Sub-unit 2B. The zeolitic silty clay contains several per cent of fish tooth debris that may indicate relatively slow local accumulation rates. The remainder of the sub-unit contains alternating marly nannofossil ooze, nannofossil ooze, and nannofossil clay. Only a 7-cm interbed of light greenish gray calcareous silty clay in Core 13 (232.06-232.13 m) breaks the sequence.

Average composition of Sub-unit $2 \mathrm{C}$ as determined from smear slides and XRD is:

$\begin{array}{lr}\text { Clay } & 55 \% \\ \text { Nannofossils } & 23 \% \\ \text { Quartz } & 10 \% \\ \text { Unspecified carbonate } & 6 \% \\ \text { Zeolite } & 2 \% \\ \text { Foraminifers } & 2 \%\end{array}$

Feldspar $\quad 2 \%$

Heavy minerals, volcanogenic glass and palagonite, siderite, and radiolarians constitute important trace components

A sample $50 \mathrm{~cm}$ above Sub-unit $2 \mathrm{C}$ in Core 11 contained no carbonate. Samples tested in Sub-unit $2 \mathrm{C}$ range from 20 to 48 per cent, average 34 per cent, and increase downward (Figure 6).

Foraminifers and nannoplankton indicate that the base of Core 11 is lowermost Danian. Upper and middle Maestrichtian microfossil assemblages in Cores 12 and 13 suggest that Sub-unit $2 \mathrm{C}$ accumulated at rates of $\sim 10 \mathrm{~m} / \mathrm{m} . \mathrm{y}$.

\section{Unit 3 - Volcanogenic Sediment (250.6-392.9 m)}

Unit 3 was intermittently cored with recovery ranging from 0 to 48 per cent (averaging 17\%). The sediments are subdivided into five sub-units (Table 2), although

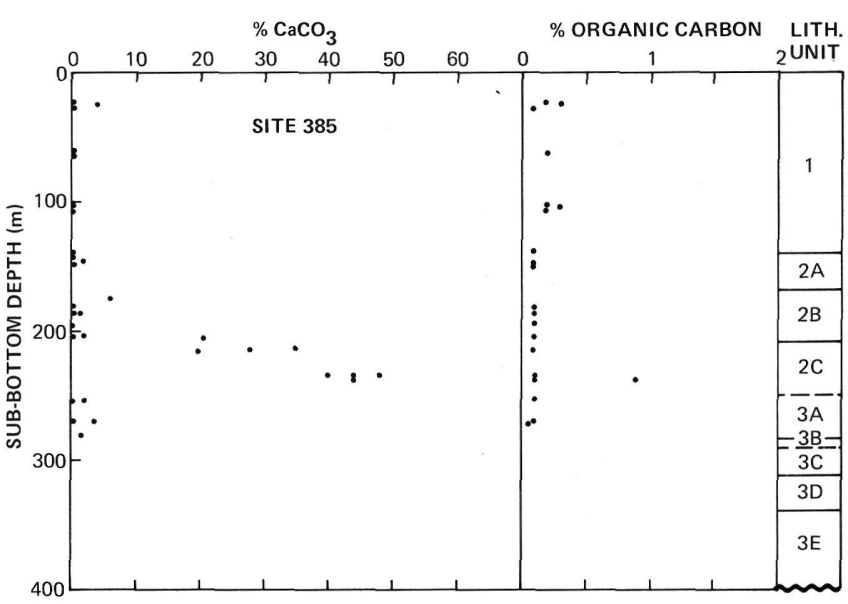

Figure 6. Carbonate and organic carbon analyses of sediments at Site 385, including shipboard determinations (Tables 3 and 4) and data from Koch and Rothe; and Cameron (this volume). 
the poor core recovery makes sub-unit thicknesses difficult to document.

\section{Sub-Unit 3A - Vitric Silty Clay (250.6-283.4 m)}

An interval of 9.6 meters was washed between Cores 13 and 14. The contact between Sub-units $2 \mathrm{C}$ and $3 \mathrm{~A}$ apparently occurs within this interval.

Sub-unit 3A (Core 14 to Core 16, Section 3, $146 \mathrm{~cm}$ ) consists of thinly stratified yellowish red clay alternating with greenish gray vitric silty clay, which becomes more vitric and siltier with depth. Core 15 contains a laminated to very thinly stratified, disturbed sequence of vitric clay interbedded with vitric muds and sands that ends abruptly in firm very dark gray, moderately to slightly mottled clay at a sub-bottom depth of 270.1 meters. A significant component of altered ash is present in the clay. Burrow fillings in this clay are enriched in manganese oxides. At a sub-bottom depth of approximately 279.9 meters (Core 16), the sub-unit becomes increasingly mottled and stratified with layers of dark red zeolitic vitric clay, dark reddish brown ferruginous vitric clayey silt, light grayish green vitric silt, and pale olive silty clay (Figure 7). Occasional poorly developed grading, cross-laminations up to $45^{\circ}$ (suggesting reworking by bottom currents or deposition from turbidity currents), inclined bedding up to $30^{\circ}$, and clastic dikes of ferruginous sandy silt are interspersed throughout. Bed thicknesses gradually increase downward to-

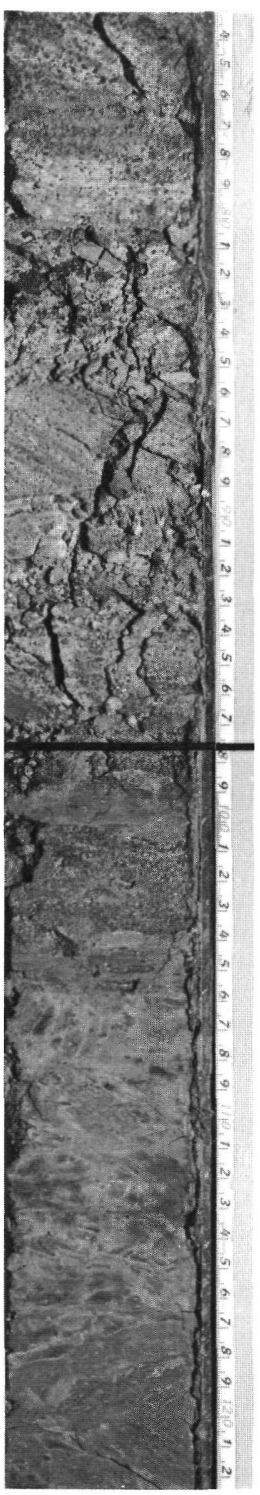

16-2: $73-123 \mathrm{~cm}$



20-1: $80-130 \mathrm{~cm}$ b

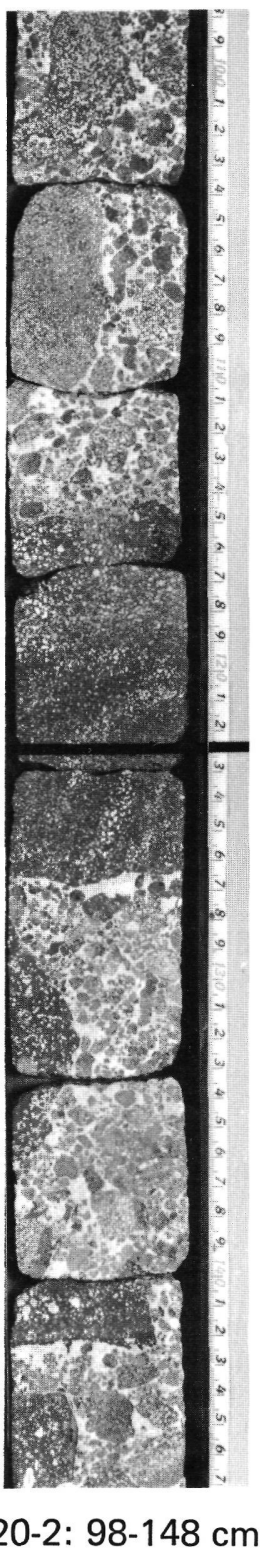

C

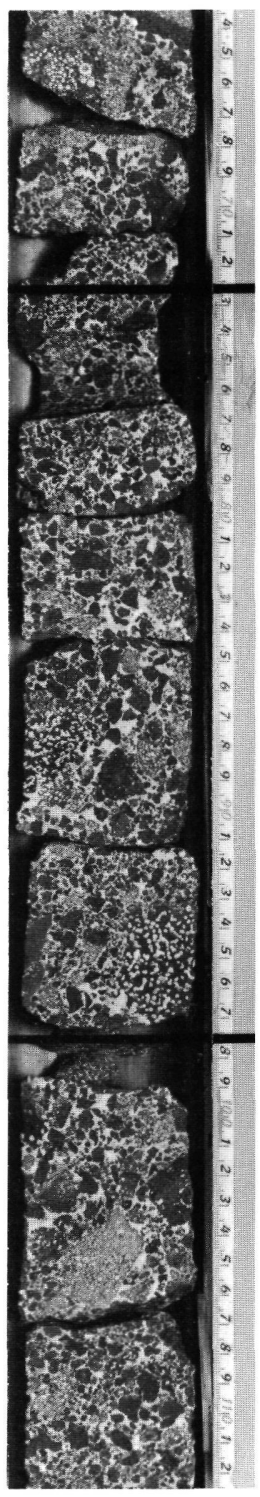

24-1: $63-113 \mathrm{~cm}$

d

Figure 7. Selected lithofacies at Site 385. (a) Sub-unit 3A-zeolitic vitric clay, ferruginous vitric clayey silt, vitric silt, and silty clay; (b) Sub-unit $3 D$-basaltic silty sand; (c, d) Subunit $3 E$-volcaniclastic breccia; note strong variations in size and angularity of basalt clasts. 
ward a contact with basalt in Core 16 , Section $3,146 \mathrm{~cm}$ at 283.36 meters sub-bottom.

The banded greenish gray vitric silty clays interbedded throughout Sub-unit 3A commonly center around a coarse (up to medium sand) layer rich in altered ash components (devitrified glass, montmorillonite, chlorite, opaques, and zeolites). Rounded pebbles of partially altered basalt ocasionally appear in these layers. Chemical changes associated with alteration of the ashy layers may have caused production of chlorite in the surrounding clays, altering their color from yellowish red to greenish gray. Such a chemical process would account for the diffuse contacts of many such beds. The ash layers probably represent sporadic eruptions on Vogel Seamount although a more distant source (perhaps adjacent Rehoboth Seamount) is possible.

Smear slide descriptions and XRD indicate an average composition (excluding carbonate) for the silty clays of:

$\begin{array}{lr}\text { Altered ash } & 45 \% \\ \text { Clay } & 38 \% \\ \text { Opaques } & 12 \% \\ \text { Zeolite } & 3 \% \\ \text { Quartz } & 1 \% \\ \text { Feldspar } & 1 \%\end{array}$

The composition of the enclosing clay is:

$\begin{array}{lr}\text { Clay } & 80 \% \\ \text { Altered ash } & 7 \% \\ \text { Quartz } & 5 \% \\ \text { Zeolite } & 4 \% \\ \text { Feldspar } & 3 \% \\ \text { Opaques } & 1 \%\end{array}$

Carbonate determinations in Sub-unit 3A range from 2 to 4 per cent $\mathrm{CaCO}_{3}$.

\section{Sub-Unit 3B - Basalt (283.4 to $>\mathbf{2 8 8 . 4} \mathrm{m}$ )}

At 283.36 meters sub-bottom depth (Core 16, Section 3,146 cm), two aphanitic grayish brown basalt fragments with lineations of unfilled vesicles along darker grayish black fracture horizons were encountered. Petrographically, the basalt is a holocrystalline, microcrystalline aphanite with felted pilotaxitic texture. Fine fluxion of plagioclase microlites and lineation of vesicles along parallel, horizontal fractures filled with montmorillonite and opaques suggest flow of the basalt while still hot. Average visual percentages in thin section are:

$\begin{array}{lr}\text { Plagioclase } & 80 \% \\ \text { Pyroxene } & 10 \% \\ \text { Opaques (magnetite) } & 6 \% \\ \text { Smectite + chlorite } & 4 \% \\ \text { Unfilled vesicles } & <1 \%\end{array}$

As no contacts were recovered intact, the origin of this basalt unit cannot be specifically determined. The horizontal orientation of basalt textures in the core, however, suggests it was in place. Origin as an intrusive sill or as a thin extrusive flow would be consistent with these data. A single K-Ar date that indicates a lower Miocene age (Houghton et al., this volume) favors the former interpretation.

In Sample 16, CC beneath $11 \mathrm{~cm}$ of similar basalt, a single light red fragment $(3 \mathrm{~cm}$ in diameter) of very altered vesicular basalt, displaying rare 1-mm black hornblende phenocrysts, was recovered. This basalt is unlike that described above in texture and composition but is identical to basaltic clasts comprising the volcaniclastic breccia of the deeper Sub-unit 3E.

Except for a few basalt fragments, Cores 17 and 18 (288.4 to $307.4 \mathrm{~m}$ ) recovered no samples. Fragments cf basalt believed to have come from the basaltic sill were found overlying subrounded fragments of volcaniclastic breccia in Core 18. The breccia fragments are similar to those recovered at Site 382 and in the underlying Subunit $3 \mathrm{E}$ at Site 385 . Lapilli of brown to reddish brown altered basalt clasts, subangular in outline and in a calcite cement, comprise this breccia. The relationships of these fragments within the sediment column is unknown, but it is assumed that the fragments were already loose in the sediment, having been transported from a source topographically higher and closer to the seamount. Rounding of the fragments could thus in part be due to transport as well as brecciation during coring. It is likely that such coarse debris in the lower part of Sub-unit 3B accounts for the poor core recovery in Cores 17 and 18.

\section{Sub-Unit 3C - Vitric Clayey Silt ( $<308.6$ to 308.9-316.8 m)}

In Section 1 in Core 19, $26 \mathrm{~cm}$ of yellowish red vitric clayey silt interbedded with intensely mottled dark brown clay having common granules of altered basalt were recovered. The sediment is very similar to the vitric silty clay of Sub-unit 3A and may be continuous with it. The only known intervening bed is the basalt sill and coarse volcaniclastic debris discussed above.

Average composition based on smear-slide descriptions and XRD is:

$\begin{array}{ll}\text { Clay } & 40 \% \\ \text { Altered ash } & 28 \% \\ \text { Volcanic glass } & 20 \% \\ \text { Opaques } & 12 \%\end{array}$

Sub-Unit 3D - Basaltic Silty Sand (308.9-316.8 to $337.8 \mathrm{~m})$

Fourteen $\mathrm{cm}$ of dark brown, loose, granular, and poorly sorted silty sand consisting of very altered fragments of basalt up to $1 \mathrm{~mm}$ in diameter were recovered in Sample 19, CC. Another $101 \mathrm{~cm}$ of sand were recovered in Core 20 , overlying the volcaniclastic breccia of Sub-unit 3E (Figure 7). Debris size increases toward the contact. Compositionally this sand is similar to Sub-unit $3 \mathrm{C}$, but with less clay and more heavy minerals (mainly hornblende) and basalt clasts. This material may represent basaltic debris transported down the flank of Vogel Seamount in gentle sand flows (Dill, 1962) and other debris flows. 


\section{Sub-Unit 3E - Volcaniclastic Breccia (337.8 to $392.9 \mathrm{~m}$ total depth)}

Fifty-five meters of nearly continuous volcaniclastic breccia were drilled with 7.5 per cent recovery (Core 20, Section 2, $32 \mathrm{~cm}$, to Sample 24, CC). Clasts are of coarse sand size up to blocks at least $22 \mathrm{~cm}$ thick and averaging $<1 \mathrm{~cm}$. The clasts are not graded and are very poorly sorted (Figure 7). The coarse fraction consists of an assortment of subangular to subrounded clasts of basalt displaying various states of alteration. Finer clastics are mostly single crystals of hornblende and pyroxene. Vesicularity varies from 3 to 30 per cent; the smaller values may be largely artificial and due to claymineral alteration products obscuring vesicles. There appears to be a crude inverse correlation between vesicularity and degree of alteration, quite the reverse of what is normally expected if the source regions are subjected to equal weathering. It is likely, therefore, that the various clasts were exposed to seawater for differing periods of time, and they may represent the results of several periods of volcanism. Recognizable vesicles are commonly filled with calcite, zeolite, montmorillonite, and rare chlorite. Many vesicles remain unfilled. Several vugs lined with euhedral calcite crystals appear throughout Sub-unit 3E.

The clasts are mostly cemented with low magnesian calcite. Phillipsite locally is an important cementing agent, but it tends to form only as radiating crystal hemispheres pressed against the basaltic walls of the cavities. Calcite fills most of the major central voids and lesser chalcedony and magnetite are present. Because clasts are more in contact than they were in the Site $\mathbf{3 8 2}$ breccias, cementing agents are relatively less important.

Although no distinct bedding is visible in the volcaniclastic breccia, certain subdivisions of the subunit are apparent. In Core 20, clasts are seldom in direct contact with each other, being separated by abundant calcite cement. Clasts in the breccia below this level have a slightly smaller mean diameter and display common grain contact.

The drilling rate from 345 to 374 meters was significantly faster than that in the rest of the sub-unit, suggesting a well-consolidated sediment layer may interrupt the breccia. In fact, a fragment of calcified silty claystone was recovered in Core $22(355.0-364.5 \mathrm{~m})$; it may represent a lithified contact with the calcitecemented breccia, but the distribution of claystone at this level in the hole is unknown. Cores 23 and 24 recovered breccia texturally very similar to the above breccia. Clasts tend to be larger and slightly fresher in this lower breccia with the areal percentage of calcite cement increasing downward, suggesting a very slight grading. Several large clasts contain relict textures indicative of their original extrusive source; core-to-rim pillow structure and horizontal entrapment of gas accumulations just below the altered rim, both of which are characteristic of flows, are present.

The poor sorting, the size and elongate shape of the largest clasts, and the slightest trace of bedding in the lower breccia support emplacement of the breccia by mass flow as envisioned for the breccia drilled at Site 382. However, alteration rims of the clasts show no evidence of hydrothermal activity; they lack the epidote and chlorite which typified many of the Site 382 breccia clasts. It seems likely, therefore, that the calcite cement was deposited from low temperature pore water. Because the immediately overlying sediments are carbonate free, it is presumed that the cement originated by remobilization of calcite from unpenetrated calcareous sediments beneath the volcaniclastic pile. Seismic profiles suggest that perhaps 1000 meters of sediments lie between the bottom of the hole and original basaltic crust (see Seismic Correlation, this chapter).

\section{Summary}

The deepest sedimentary rock recovered at Site $\mathbf{3 8 5}$ is part of the volcaniclastic apron of Vogel Seamount. Abundant calcite cement in the breccia, probably was remobilized from underlying sediment suggesting that deeper sediments adjacent to the seamount were deposited above the CCD. The paucity of carbonate interbeds in the breccia suggests that Site 385 was below the CCD during deposition of the breccia. Similarly, the lack of carbonate fossils and interbeds in the overlying volcanogenic unit suggests a relatively high $\mathrm{CCD}$. Poorly sorted, unstratified basaltic silty sands sitting immediately above the basaltic breccia are interpreted as debris or sand flows. Sporadic eruptions of Vogel or possibly another nearby seamount (Rehoboth?) are recorded in the vitric silty clays of Sub-units $3 \mathrm{~A}$ and $3 \mathrm{C}$. Color banding and lack of calcareous clay indicate that deposition occurred in a pelagic regime still below the CCD. The age of volcanism on Vogel Seamount can be dated only as pre-middle Maestrichtian.

A deepening of the CCD in the Maestrichtian to earliest Danian is required to explain the marly oozes of Sub-unit 2C. Early Danian shoaling of the CCD led to deposition of zeolitic silty clays and non-calcareous radiolarian clays and oozes of Sub-units $2 \mathrm{~B}$ and $2 \mathrm{~A}$ through early Eocene. The overlying upper Oligocene hemipelagic clays also are devoid of carbonate and were deposited below the CCD. Some renewed volcanism in the lower Miocene is suggested by the basaltic sill of Sub-unit 3B. Deposition below the CCD apparently prevailed until shortly before Holocene time when nannofossil-foraminiferal ooze was deposited near the present sea floor depth.

\section{Comparison of Sites 382 and 385 Stratigraphic Sections}

Because both sites were drilled on flanks of volcanic peaks along the New England Seamount chain and were separated by only about $450 \mathrm{~km}$, the stratigraphic sequences at the two sites can be easily compared (Figure 8).

While the section on Nashville Seamount (Site 382) was capped by a thick $(232 \mathrm{~m})$ section of turbidites, Quaternary sedimentation at Vogel Seamount (Site 385) is represented by only a thin (probably $<22 \mathrm{~m}$ ) veneer of pelagic nannofossil foraminiferal ooze. Had Site 382 been drilled into the acoustically non-laminated 


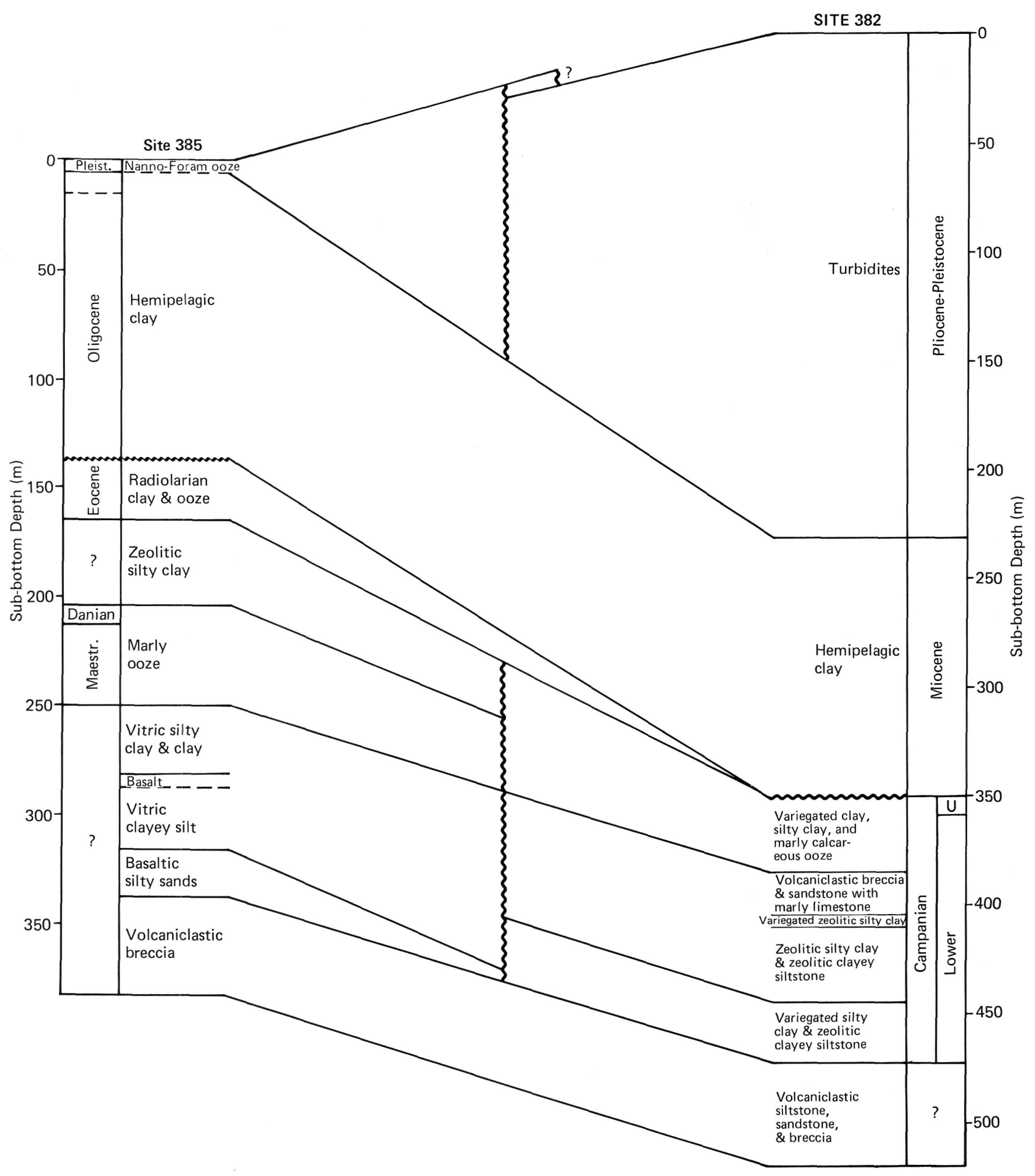

Figure 8. Comparison of stratigraphic sections at Site 382 and 385.

sediments on the flank of Nashville Seamount above the Sohm Abyssal Plain, similar Quaternary oozes probably would have been recovered. Submersible dives by Alvin on Rehoboth Seamount, just north of Vogel, indicate a similar stratigraphy of ooze over hemipelagic sediment
(Houghton and Ballard, in preparation). At least at Rehoboth Seamount fairly strong northeast-flowing currents keep the pelagic material swept clear in places, forming windows to the underlying edaphogenous and hemipelagic sediments. 
Both Sites 382 and 385 drilled Tertiary hemipelagic clay sequences; clay, quartz, and feldspar comprise 97 per cent of the Nashville hemipelagics and 96 per cent of those at Vogel. Burrows and mottles in the hemipelagic clays of Nashville are enriched in pyrite and hydrotroilite, indicating sub-surface reducing conditions existed. Sulfide enrichments are absent from burrows in Vogel hemipelagics, but the burrows are somewhat enriched in glauconite. As glauconite forms in either weakly reducing or weakly oxidizing conditions (Larsen and Chilingar, 1967), sub-surface reducing microenvironments may have prevailed at Vogel. Hemipelagic clays at Nashville range in age from lower Miocene to upper Pliocene and at Vogel from middle Eocene to Quaternary. Thicknesses are nearly the same at the two sites, but thickness comparisons are difficult because both sites may have Neogene disconformities within the hemipelagic units. At Site 382, the middle Miocene may be missing, whereas at Site 385, lower Quaternary through lower Miocene sediments are missing or condensed. These compressed sections indicate that the New England seamount area was characterized by erosion or slow accumulation at least during midMiocene time.

A disconformity occurs at the base of the hemipelagic sequences at both the Nashville and Vogel sites. At Nashville, the hiatus represents about 50 m.y. and separates the hemipelagic sediments from underlying upper Campanian volcanogenics. At Vogel, the hiatus represents only about $25 \mathrm{~m} . \mathrm{y}$. and separates the hemipelagics from an underlying middle Eocene to Maestrichtian pelagic unit not present at Nashville.

The lowest lithofacies cored on both seamounts represents a volcaniclastic apron consisting of varying amounts of clay, silt, sand, and lapilli breccia cemented mostly with calcite and lesser zeolite.

Because Site 382 is the further from its associated volcanic peak, the volcaniclastic breccia at Nashville Seamount better displays sedimentary structures crucial to a genetic interpretation. Sorting, although poor, delineates beds within the volcaniclastic unit of Nash- ville and suggests emplacement by a slump process or fluxoturbidite. On Vogel, except for a general grading indicated by the emplacement of sands overlying breccia, the volcaniclastic sequence is structureless and could have resulted from slumping or simply accumulated as a talus pile, as suggested by the high degree of interclast contact. The thickness of the unit favors the slumping, however. Site 385 is nearer its source peak, and the volcaniclastic unit is coarser in texture and more lithic and less crystalline in composition. Furthermore, the breccia cement on Vogel contains a higher percentage of phillipsite. Because the zeolite probably formed by basaltic alteration (Houghton, this volume), it may be that Vogel is older than Nashville or that less calcite could be mobilized for recrystallization in the Vogel breccias. Lack of microfossils to date the section does not allow distinction between these two possibilities. Whereas basaltic clasts at Nashville are less altered than their counterparts at Vogel, radiometric dating and its assorted errors (Houghton, et al., this volume) does not rule out essentially synchronous volcanism at the two sites.

\section{GEOCHEMISTRY}

\section{Carbon, Nitrogen}

Shipboard and post-cruise analyses for organic carbon indicate that the sediments at Site 385 contain less than 0.3 per cent organic carbon (Figure 6, Table 3). The $\mathrm{C} / \mathrm{N}$ ratios for the sediments average about 5 . Such values of $\mathrm{C} / \mathrm{N}$ in deep-sea sediments are low, but not rare (Stevenson and Cheng, 1972). However, because a significant fraction of the nitrogen could be inorganic in nature, the $\mathrm{C} / \mathrm{N}$ ratios may not accurately reflect the composition of organic matter in the sediments.

\section{Calcium Carbonate}

Shipboard bomb measurements (Table 4) and shorelab analyses indicate that $\mathrm{CaCO}_{3}$ is a minor component in most sediments at Site 385 (Figure 6). The exception to this generalization occurs between 205 and 250 meters (Cores 11-13), where earliest Danian to Maestrichtian

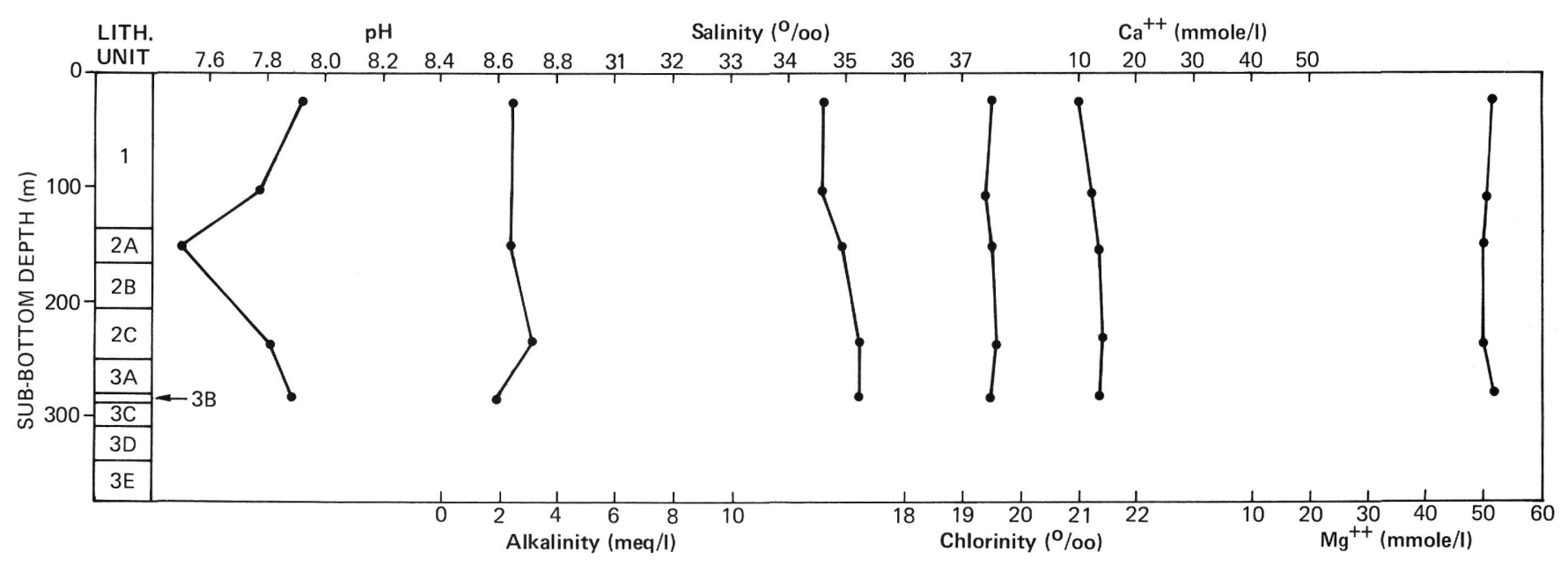

Figure 9. Interstitial water chemistry at Site 385. 
TABLE 3

Shipboard Carbon, Nitrogen Measurements, Site $385^{\mathrm{a}}$

\begin{tabular}{lcrrr}
\hline $\begin{array}{c}\text { Sample } \\
\text { (Interval in cm) }\end{array}$ & $\begin{array}{c}\text { Depth Below } \\
\text { Sea Floor (m) }\end{array}$ & $\% \mathrm{C}_{\text {org }}$ & $\% \mathrm{~N}$ & $\frac{\mathrm{C}}{\mathrm{N}}$ \\
\hline $1-2,130$ & 25.1 & 0.3 & 0.07 & 4 \\
$3-4,130$ & 104.3 & 0.3 & 0.06 & 5 \\
$5-2,130$ & 148.9 & 0.1 & 0.01 & 10 \\
$13-2,150$ & 234.6 & 0.1 & 0.03 & 3 \\
$15-1,112-113$ & 270.7 & $<0.1$ & 0.02 & - \\
\hline
\end{tabular}

${ }^{a}$ Additional shore-lab data are given in Cameron (this volume).

TABLE 4

Shipboard $\mathrm{CaCO}_{3}$ Measurements, ${ }^{\mathrm{a}}$ Site 385

\begin{tabular}{lcc}
\hline $\begin{array}{c}\text { Sample } \\
\text { (Interval in cm) }\end{array}$ & $\begin{array}{c}\text { Depth Below } \\
\text { Sea Floor (m) }\end{array}$ & \%CaCO 3 \\
\hline $1-2,75-76$ & 24.6 & 4 \\
$2-2,75-76$ & 62.7 & 0 \\
$3-2,75-76$ & 100.8 & 0 \\
$4-2,75-76$ & 138.8 & 0 \\
$5-2,75-76$ & 148.4 & 2 \\
$8-1,126-127$ & 175.9 & 6 \\
$9-1,110-111$ & 185.2 & 1 \\
$11-2,75-76$ & 205.3 & 0 \\
$11-2,135-136$ & 205.9 & 21 \\
$12-2,13-14$ & 214.1 & 35 \\
$12-2,75-76$ & 214.8 & 20 \\
$13-2,35-36$ & 233.5 & 40 \\
$13-2,118-119$ & 234.3 & 48 \\
$14-2,75-76$ & 252.9 & 2 \\
$15-1,75-76$ & 270.4 & 4 \\
$16-2,49-50$ & 280.9 & 2 \\
\hline
\end{tabular}

${ }^{\mathrm{a}}$ Carbonate bomb method. Additional shorelab data are given in Koch and Rothe; and Cameron (both in this volume).

sediments contain 20 to 50 per cent $\mathrm{CaCO}_{3}$. Similar Maestrichtian depression of the CCD is indicated at Sites 386 and 387 (see Tucholke and Vogt, this volume).

\section{Interstitial Water Chemistry}

The results of the interstitial water analyses are summarized in Table 5 and Figure 9. The downhole variations in the pore water chemistry are generally small. An increase in the alkalinity at $\mathbf{2 3 6}$ meters may be related to increased dissolution of $\mathrm{CaCO}_{3}$ within the interval of calcareous Maestrichtian sediments.

\section{PHYSICAL PROPERTIES}

At Site 385 the compressional wave velocity, undrained shear strength, wet bulk density, and other bulk properties such as water content and porosity were determined for representative test specimens. These data are listed in Table 6 and the test methods and systems errors associated with the test techniques are given in the physical properties section of the Site 382 Report. Test specimens are typically taken from the lower half of each core, which appears to be least disturbed and most representative of in-situ conditions. However, as a check on disturbance within cores, specimens from upper core sections occasionally were tested. Only cohesive sediment specimens with a minimum of visual distortion are used in order to obtain the best possible estimate of physical properties.

\section{Shear Strength}

The depth variation of shear strength is shown in Figure 10, and considerable scatter is observed in the test data. However, to a sub-bottom depth of about 105 meters there is a nearly linear increase in strength with depth. The random distribution of data below 105 meters may be explained in part by poor sample recovery, disturbance, and varying mineralogies. The addition of water during the coring process as a factor influencing physical properties does not appear likely in these sediments; however, temperature changes and drained unloading after core recovery may have a significant influence upon shear strength data. Vane shear tests were terminated on samples from a depth of 185 meters where the sediment became brittle and fractured upon insertion of the vane.

\section{Bulk Properties}

Water content data are shown in Figure 11, and water content values generally appear to decrease with subbottom depth, as expected from the compaction process. In the upper 165 meters, hemipelagic clay and radiolarian clay were recovered. In this zone the water contents are approximately constant within each core, but they vary erratically between cores. These data suggest that the sediments are homogeneous within each core as visually observed, yet there are slight differences in the textural and mineralogical composition between cores. Chert fragments were recovered in Core 6, CC and Core 7. Below this chert pelagic clays, oozes, and

TABLE 5

Interstitial Water Chemistry, Site 385

\begin{tabular}{cccccccc}
\hline $\begin{array}{c}\text { Sample } \\
\text { (Interval in cm) }\end{array}$ & $\begin{array}{c}\text { Depth Below } \\
\text { Sea Floor (m) }\end{array}$ & $p \mathrm{H}$ & $\begin{array}{c}\text { Alkalinity } \\
(\mathrm{meq} / \mathrm{l})\end{array}$ & $\begin{array}{c}\text { Salinity } \\
(\% / \%)\end{array}$ & $\begin{array}{c}\text { Chlorinity } \\
(\% / \mathrm{o})\end{array}$ & $\begin{array}{c}\mathrm{Ca}^{++} \\
(\mathrm{m} \text { mole/l) }\end{array}$ & $\begin{array}{c}\mathrm{Mg}^{++} \\
(\mathrm{m} \mathrm{mole} / \mathrm{l})\end{array}$ \\
\hline Surface seawater & - & 8.77 & 2.41 & 35.5 & 20.0 & 10.9 & 56.0 \\
$1-3,144-150$ & 26.8 & 7.92 & 2.44 & 34.6 & 19.5 & 10.0 & 51.5 \\
$3-5,144-150$ & 106.0 & 7.77 & 2.42 & 34.6 & 19.4 & 12.3 & 50.5 \\
$5-3,140-150$ & 151.6 & 7.51 & 2.39 & 34.9 & 19.5 & 13.2 & 49.9 \\
$13-3,140-150$ & 236.1 & 7.80 & 3.13 & 35.2 & 19.6 & 14.0 & 49.9 \\
$16-2,140-150$ & 281.9 & 7.87 & 1.88 & 35.2 & 19.5 & 13.3 & 51.4 \\
\hline
\end{tabular}


TABLE 6

Physical Properties Data, Site 385

\begin{tabular}{|c|c|c|c|c|c|c|c|c|c|c|c|c|c|}
\hline \multirow[b]{3}{*}{$\begin{array}{c}\text { Sample } \\
\text { (Interval in } \mathrm{cm} \text { ) }\end{array}$} & \multirow[b]{3}{*}{$\begin{array}{l}\text { Sub-Bottom } \\
\text { Depth }(\mathrm{m})\end{array}$} & \multirow{2}{*}{\multicolumn{2}{|c|}{$\begin{array}{l}\text { Velocity } \\
(\mathrm{km} / \mathrm{sec})\end{array}$}} & \multirow{2}{*}{ 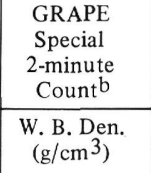 } & \multirow{2}{*}{\multicolumn{2}{|c|}{$\begin{array}{l}\text { GRAPE } \\
\text { Routine }{ }^{a, b}\end{array}$}} & \multirow{3}{*}{$\begin{array}{c}\text { Thermal } \\
\text { Conduc- } \\
\text { tivityc } \\
\text { (mcal/ } \\
\text { cm-sec- }^{\circ} \mathrm{C} \text { ) }\end{array}$} & \multirow{3}{*}{$\begin{array}{l}\text { Shear } \\
\text { Strength } \\
\text { Undist./ } \\
\text { Rem. } \\
\left(\mathrm{g} / \mathrm{cm}^{2}\right)\end{array}$} & \multirow{2}{*}{\multicolumn{3}{|c|}{ Syringe or Rock Chunk }} & \multirow[b]{3}{*}{$\begin{array}{c}\text { Impedance } \\
\left(\mathrm{g} / \mathrm{cm}^{2}-\right. \\
\mathrm{sec}) \times 10^{5}\end{array}$} & \multirow[b]{3}{*}{ Lithology } \\
\hline & & & & & & & & & & & & & \\
\hline & & $\begin{array}{l}\quad(\mathrm{km} / \\
\text { Para. } \\
\text { Beds }\end{array}$ & $\begin{array}{l}\text { /sec) } \\
\text { Perp. } \\
\text { Beds }\end{array}$ & \begin{tabular}{l}
\multicolumn{2}{c}{$\left(\mathrm{g} / \mathrm{cm}^{3}\right)$} \\
Para. \\
Beds
\end{tabular} & $\begin{array}{l}\text { W. B. } \\
\text { Den. } \\
\left(\mathrm{g} / \mathrm{cm}^{3}\right)\end{array}$ & $\begin{array}{l}\text { Por. } \\
(\%)\end{array}$ & & & $\begin{array}{c}\text { Water } \\
\text { Cont. } \\
(\%)\end{array}$ & $\begin{array}{l}\text { Wet Bulk } \\
\text { Den. } \\
\left(\mathrm{g} / \mathrm{cm}^{3}\right)\end{array}$ & $\begin{array}{l}\text { Por. } \\
(\%)\end{array}$ & & \\
\hline $\begin{array}{l}1-2,14-22 \\
1-4,57-62 \\
1-4,125-134 \\
2-6,37-45 \\
2-6,107-118\end{array}$ & $\begin{array}{l}24.0 \\
27.4 \\
28.1 \\
69.1 \\
69.8\end{array}$ & $\begin{array}{l}1.48 \\
1.49 \\
1.50\end{array}$ & & & $\begin{array}{l}1.47 \\
1.47 \\
1.30 \\
1.30\end{array}$ & $\begin{array}{l}72 \\
72 \\
83 \\
83\end{array}$ & & $\begin{array}{l}139 / 48 \\
164 / 56 \\
160 / 56 \\
413 / 51 \\
589 / 158\end{array}$ & $\begin{array}{l}50 \\
49 \\
50 \\
61 \\
60\end{array}$ & $\begin{array}{l}1.42 \\
1.43 \\
1.42 \\
1.31 \\
1.38\end{array}$ & $\begin{array}{l}71 \\
70 \\
71 \\
80 \\
83\end{array}$ & $\begin{array}{l}2.10 \\
2.12 \\
2.07\end{array}$ & $\begin{array}{l}\text { Green clay } \\
\text { Green clay } \\
\text { Green clay } \\
\text { Gray-green clay } \\
\text { Gray-green clay }\end{array}$ \\
\hline $\begin{array}{l}3-3,75-80 \\
3-3,80-97 \\
3-6,80-87 \\
3-6,112-124 \\
3-6,128-129\end{array}$ & $\begin{array}{l}102.5 \\
102.6 \\
107.1 \\
107.4 \\
107.5\end{array}$ & $\begin{array}{l}1.51 \\
1.51\end{array}$ & & & & & & $\begin{array}{l}482 / \\
561 / \\
538 / \\
334 / \\
315 /\end{array}$ & $\begin{array}{l}52 \\
53 \\
53\end{array}$ & $\begin{array}{l}1.54 \\
1.38 \\
1.43\end{array}$ & $\begin{array}{l}76 \\
73 \\
76\end{array}$ & 2.16 & $\begin{array}{l}\text { Gray-green clay } \\
\text { Gray-green clay } \\
\text { Gray-green clay } \\
\text { Gray-green clay } \\
\text { Gray-green clay }\end{array}$ \\
\hline $\begin{array}{l}4-2,121-137 \\
4-3,67-76 \\
4-3,81-86 \\
5-1,138-144 \\
5-3,122-135\end{array}$ & $\begin{array}{l}139.3 \\
140.2 \\
140.3 \\
147.5 \\
150.4\end{array}$ & $\begin{array}{l}1.53 \\
1.53 \\
1.54 \\
1.55\end{array}$ & 1.53 & & $\begin{array}{l}1.18 \\
1.25 \\
1.25 \\
1.29\end{array}$ & $\begin{array}{l}91 \\
86 \\
86 \\
84\end{array}$ & & $\begin{array}{l}510 / \\
454 / \\
380 / \\
\\
500 /\end{array}$ & $\begin{array}{l}54 \\
\\
54 \\
58 \\
58\end{array}$ & $\begin{array}{l}1.35 \\
1.36 \\
1.36 \\
1.30\end{array}$ & $\begin{array}{l}72 \\
74 \\
78 \\
75\end{array}$ & $\begin{array}{l}1.99 \\
2.10^{\mathrm{d}} \\
2.08 \\
2.02\end{array}$ & $\begin{array}{l}\text { Light brown-green rad ooze } \\
\text { Light brown-green rad ooze } \\
\text { Light brown-green rad ooze } \\
\text { Pink-brown rad clay } \\
\text { Pink-brown rad clay }\end{array}$ \\
\hline $\begin{array}{l}6, \mathrm{CC} \\
8-1,122-139 \\
8-5,106-116 \\
9-1,99-110 \\
10-1,100-101\end{array}$ & $\begin{array}{l}(155.6) \\
175.9 \\
181.7 \\
185.1 \\
194.4\end{array}$ & $\begin{array}{l}1.55^{-3.1} \\
1.54 \\
1.60 \\
1.95\end{array}$ & $\begin{array}{l}10- \\
1.58 \\
1.76\end{array}$ & & $\begin{array}{l}1.51 \\
1.53 \\
1.38\end{array}$ & $\begin{array}{l}70 \\
69 \\
78\end{array}$ & & $\begin{array}{l}284 / 105 \\
239 / \\
329 /\end{array}$ & $\begin{array}{r}5 \\
42 \\
43 \\
29\end{array}$ & $\begin{array}{l}1.94 \\
1.54 \\
1.50 \\
1.73\end{array}$ & $\begin{array}{l}10 \\
64 \\
64 \\
50\end{array}$ & $\begin{array}{l}6.01 \\
2.37 \\
2.37 \\
3.04\end{array}$ & $\begin{array}{l}\text { Chert } \\
\text { Light pink-brown clay } \\
\text { Light pink-brown clay } \\
\text { Light pink-brown clay } \\
\text { Gray claystone }\end{array}$ \\
\hline $\begin{array}{l}10-1,124-125 \\
11-1,82-83 \\
11-1,148-149 \\
12-2,20-21 \\
12-2,122-123\end{array}$ & $\begin{array}{l}194.6 \\
203.8 \\
204.5 \\
214.2 \\
215.2\end{array}$ & $\begin{array}{l}1.59 \\
1.60 \\
1.60\end{array}$ & $\begin{array}{l}1.98 \\
1.60 \\
1.60 \\
1.60\end{array}$ & & $\begin{array}{l}1.77 \\
1.77\end{array}$ & $\begin{array}{l}54 \\
54\end{array}$ & & & $\begin{array}{l}27 \\
40 \\
35 \\
28 \\
26\end{array}$ & $\begin{array}{l}1.73 \\
1.62 \\
1.67 \\
1.85 \\
1.84\end{array}$ & $\begin{array}{l}47 \\
64 \\
58 \\
51 \\
49\end{array}$ & $\begin{array}{l}3.43 \\
2.58 \\
2.67 \\
2.96 \\
2.94\end{array}$ & $\begin{array}{l}\text { Gray claystone } \\
\text { Gray clay } \\
\text { Gray clay } \\
\text { Gray-blue clay } \\
\text { Red-brown clay }\end{array}$ \\
\hline $\begin{array}{l}13-4,73-74 \\
13-4,144-145 \\
14-2,100-101 \\
14-3,148-149 \\
15-1,27-28\end{array}$ & $\begin{array}{l}236.8 \\
237.5 \\
253.1 \\
255.1 \\
269.9\end{array}$ & $\begin{array}{l}1.68 \\
1.65 \\
1.64\end{array}$ & $\begin{array}{l}1.60 \\
1.60 \\
1.62 \\
1.62\end{array}$ & & $\begin{array}{l}1.74 \\
1.74 \\
1.72 \\
1.75\end{array}$ & $\begin{array}{l}56 \\
56 \\
58 \\
56\end{array}$ & & & $\begin{array}{l}29 \\
31 \\
30 \\
31 \\
31\end{array}$ & $\begin{array}{l}1.84 \\
1.80 \\
1.79 \\
1.78 \\
1.78\end{array}$ & $\begin{array}{l}53 \\
55 \\
54 \\
56 \\
55\end{array}$ & $\begin{array}{l}2.94 \\
2.88 \\
2.90 \\
2.88 \\
2.92\end{array}$ & $\begin{array}{l}\text { Red-brown clay } \\
\text { Gray clay } \\
\text { Red claystone } \\
\text { Red claystone } \\
\text { Red claystone }\end{array}$ \\
\hline $\begin{array}{l}15-1,108-109 \\
16-2,129-130 \\
16-3,10-11 \\
16-3,132-133 \\
16, \text { CC }\end{array}$ & $\begin{array}{c}270.7 \\
281.7 \\
282.0 \\
283.2 \\
(283.5)\end{array}$ & $\begin{array}{l}1.63 \\
1.62 \\
1.59 \\
-4.4\end{array}$ & $\begin{array}{l}1.58 \\
1.59 \\
1.58 \\
1.57 \\
4-\end{array}$ & & $\begin{array}{l}1.67 \\
1.72 \\
1.72\end{array}$ & $\begin{array}{l}60 \\
57 \\
57\end{array}$ & & & $\begin{array}{l}31 \\
34 \\
35 \\
34\end{array}$ & $\begin{array}{l}1.78 \\
1.75 \\
1.73 \\
1.73 \\
2.60\end{array}$ & $\begin{array}{l}56 \\
60 \\
60 \\
59\end{array}$ & $\begin{array}{r}2.81 \\
2.78 \\
2.73 \\
2.72 \\
11.54\end{array}$ & $\begin{array}{l}\text { Brown claystone } \\
\text { Dark brown claystone } \\
\text { Dark brown claystone } \\
\text { Dark brown claystone } \\
\text { Basalt }\end{array}$ \\
\hline $\begin{array}{l}16, \mathrm{CC} \\
18, \mathrm{CC} \\
18, \mathrm{CC} \\
19, \mathrm{CC} \\
20-2,80-81\end{array}$ & $\begin{array}{l}(283.5) \\
(297.9) \\
(297.9) \\
(309.4) \\
338.3\end{array}$ & $\begin{array}{l}-4.4 \\
-1.7 \\
-4.0 \\
-2.8 \\
3.59\end{array}$ & & $-2.43-$ & 1.99 & 41 & & & $\begin{array}{r}38 \\
21 \\
8\end{array}$ & $\begin{array}{l}2.60 \\
1.71 \\
2.02 \\
2.35\end{array}$ & $\begin{array}{l}64 \\
43 \\
19\end{array}$ & $\begin{array}{c}11.44 \\
2.94 \\
8.18 \\
6.63 \\
8.72 \mathrm{~d}\end{array}$ & $\begin{array}{l}\text { Basalt } \\
\text { Volcanic ash? } \\
\text { Breccia } \\
\text { Claystone } \\
\text { Breccia }\end{array}$ \\
\hline $\begin{array}{l}20-2,115-116 \\
20-2,137-138 \\
21, \text { CC } \\
22, \text { CC } \\
23-2,145-146\end{array}$ & $\begin{array}{c}338.7 \\
338.9 \\
(345.5) \\
(355.0) \\
376.9\end{array}$ & $\begin{array}{c}3.63 \\
3.56 \\
-3.3 \\
\\
3.03\end{array}$ & $\begin{array}{l}3.41 \\
35- \\
2.74\end{array}$ & $\begin{array}{l}-2.38- \\
-2.47-\end{array}$ & $\begin{array}{l}1.99 \\
1.99\end{array}$ & $\begin{array}{l}41 \\
41\end{array}$ & & & $\begin{array}{r}8 \\
16\end{array}$ & $\begin{array}{l}2.46 \\
2.16\end{array}$ & $\begin{array}{l}20 \\
36\end{array}$ & $\begin{array}{l}8.64 \mathrm{~d} \\
8.42^{\mathrm{d}} \\
\\
6.74 \\
6.54\end{array}$ & $\begin{array}{l}\text { Breccia } \\
\text { Breccia } \\
\text { Breccia } \\
\text { Red claystone } \\
\text { Breccia }\end{array}$ \\
\hline $\begin{array}{l}23-3,110-111 \\
24-1,32-33 \\
24-1,132-133\end{array}$ & $\begin{array}{l}378.1 \\
383.8 \\
384.8\end{array}$ & $\begin{array}{l}3.43 \\
3.35 \\
3.58\end{array}$ & $\begin{array}{l}3.39 \\
3.68 \\
3.61\end{array}$ & & & & & & $\begin{array}{l}16 \\
14 \\
11\end{array}$ & $\begin{array}{l}2.23 \\
2.24 \\
2.34\end{array}$ & $\begin{array}{l}34 \\
32 \\
27\end{array}$ & $\begin{array}{l}7.56 \\
8.24 \\
8.45\end{array}$ & $\begin{array}{l}\text { Breccia } \\
\text { Breccia } \\
\text { Breccia }\end{array}$ \\
\hline
\end{tabular}

${ }^{a}$ Routine GRAPE values are averages for entire core section, normally based on eight measurements between 10 and $140 \mathrm{~cm}$ in section. A complete listing of routine GRAPE data is given in the Appendix.

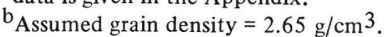

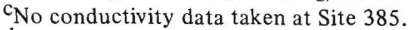

${ }^{\mathrm{d}}$ Determined using GRAPE density ( 2 min. count preferred, otherwise section average).

volcanogenic clays were cored to a depth of 283 meters. The water content data suggest that upper sections of some cores containing these clays and oozes were subjected to drained unloading and swelling (see Demars et al., this volume); however, the trend is not as clearly defined as it is in the nannofossil ooze at Site 384. Below 283 meters, beds of breccia, volcanogenic claystone and basalt were recovered with water contents typically less than 20 per cent.

\section{Density and Acoustic Velocity}

Wet bulk density, acoustic velocity, and acoustic impedance (density times velocity) also are plotted in Figure 11. Wet bulk densities for the hemipelagic and radiolarian clays remain approximately constant at about $1.40 \mathrm{~g} / \mathrm{cm}^{3}$ to a depth of 165 meters. A large chert fragment in Core 6, CC $(165 \mathrm{~m})$ has a density of 1.94 $\mathrm{g} / \mathrm{cm}^{3}$; other very small chert fragments in Core 7 were 


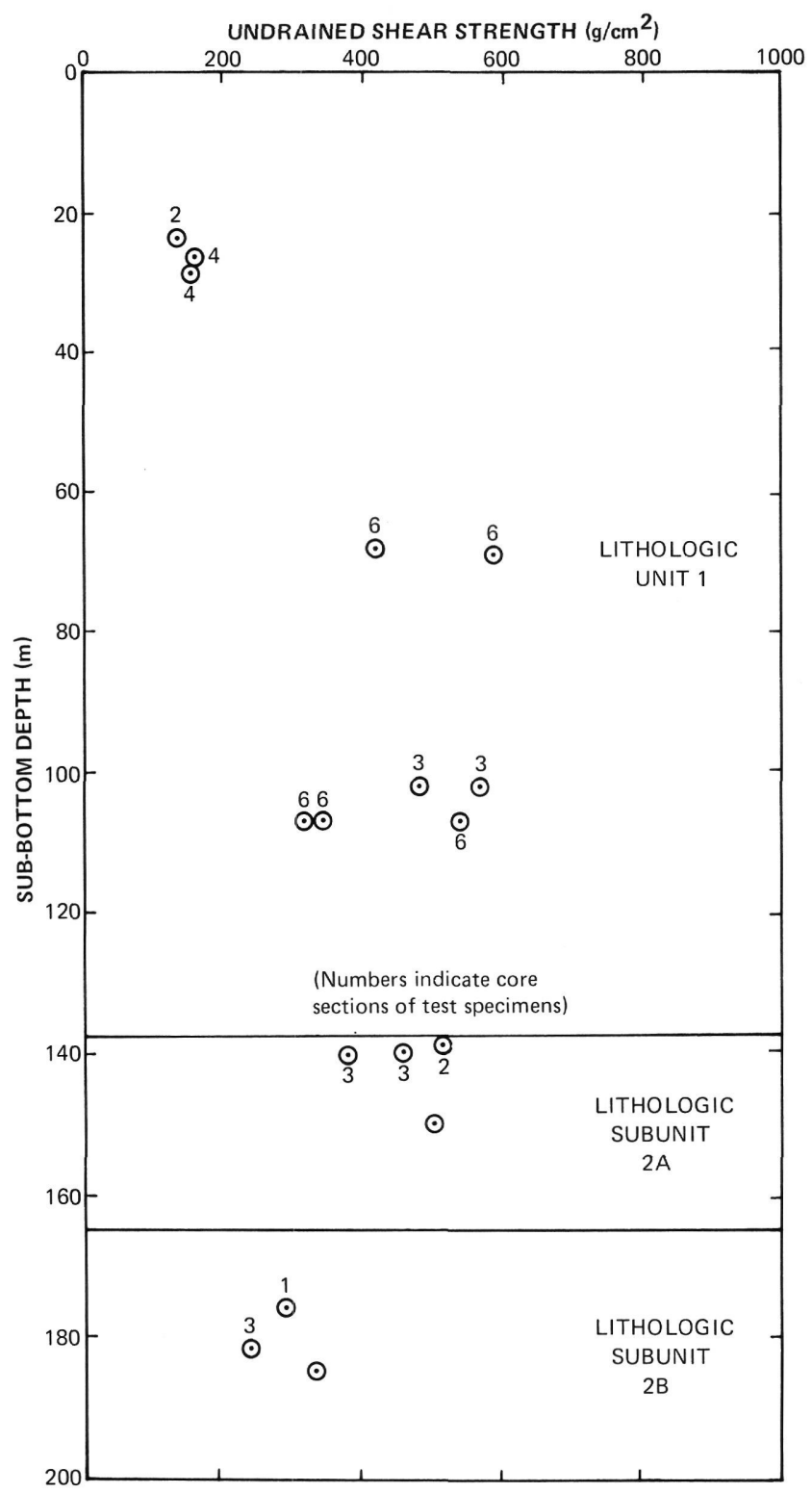

Figure 10. Undrained shear strength of Site 385 sediments.

unsuitable for testing. Bulk densities increase rapidly with depth in the zeolitic silty clays (lithologic Sub-unit $2 \mathrm{C}$ ) and remain approximately constant at $1.80 \mathrm{~g} / \mathrm{cm}^{3}$ in the underlying marly oozes. The volcanogenic sediments below 251 meters have highly variable bulk densities, ranging from about $1.70 \mathrm{~g} / \mathrm{cm}^{3}$ in vitric silty clays, through about $2.4-2.5 \mathrm{~g} / \mathrm{cm}^{3}$ in breccias, to $2.6 \mathrm{~g} / \mathrm{cm}^{3}$ in a thin basalt layer (Sub-unit 3B).

Acoustic velocities average $1.55 \mathrm{~km} / \mathrm{sec}$ to a depth of 290 meters. Only a slight increase in velocity with depth is observed and, in general, the velocities in the clay/claystone appear to be unaffected by density changes and compositional variations. The cherts and the basalts, claystones, and breccias (lithologic Unit 3) have measured velocities that range from 1.72 to 4.40 $\mathrm{km} / \mathrm{sec}$, and a thin claystone layer at 195 meters has a velocity of $2.0 \mathrm{~km} / \mathrm{sec}$. The degree of particle cementation appears to be the primary factor influencing compressional wave velocities. Impedance contrasts suggest that the major acoustic reflectors are the cherts, and the basalt, claystone, and breccia layers which form one or more reflective units below about 288 meters.

\section{BIOSTRATIGRAPHIC SUMMARY}

Site 385, drilled on the flank of Vogel Seamount to determine the age of volcanic activity in this part of New England seamount chain, unfortunately did not yield datable fossils in the volcanogenic sediment. The oldest dated sediment is middle Maestrichtian. Biostratigraphical information in the 24 cores recovered at this site is generally poor.

Core 1 has a $20-\mathrm{cm}$ thick section of foraminiferal ooze at the top of Section 1. This section of core is probably surface sediment accidentally recovered because of the time gap between actual "touch down" and driller's "feeling for bottom" without circulation. Both foraminifera and nannoplankton are warm-water assemblages with a minor cold facies of Quaternary age. Sample 1, CC, although barren of nannofossils, contains foraminifers indicating a cool-water assemblage of the same period.

Cores 2 through 10 yielded no calcareous fossils, but contain abundant radiolarians. Cores 2 and 3 are assigned to the upper Oligocene, which disconformably overlies lower-middle to upper-lower Eocene assemblages (Cores 4 to 6). Although radiolarians are frequently found in Cores 7 through 10, their poor preservation makes age determination very difficult.

In the bottom of Core 11, approximately $20 \mathrm{~cm}$ of calcareous sediment were recovered. Both foraminiferal and nannoplankton assemblages clearly show an earliest Danian date for this sediment. The first occurrence of Cruciplacolithus tenius (bottom of NP 2) was recognized within this section of core. Up to now it has been rather unusual to recover fossiliferous sediments of early Danian age during deep-sea drilling. However, two consecutive sites on this leg produced this rare recovery and provide significant information for paleoceanographic as well as paleontological studies of the beginning of the Cenozoic era. The nannoflora suggests the lower Danian sediment at Site $\mathbf{3 8 5}$ is a rather neritic type, although not as shallow as that at Site 384 .

Unfortunately, we did not recover sediment across the Cretaceous/Tertiary boundary at this site. Only two sections $(2.3 \mathrm{~m})$ were recovered in Core 11 and the core catcher was empty. Core 12 also recovered only 2.15 meters, although coring was continuous between these two cores. Thus, approximately 8 to 16 meters of sediment were not recovered across the boundary. Upper Maestrichtian species have been reworked upward into the Danian sediment. The Cretaceous/Tertiary boundary was probably within 1 meter of the bottom of Core 11.

The sudden disappearance of calcareous fossils above lower part of NP 2 seems to indicate shoaling of the 


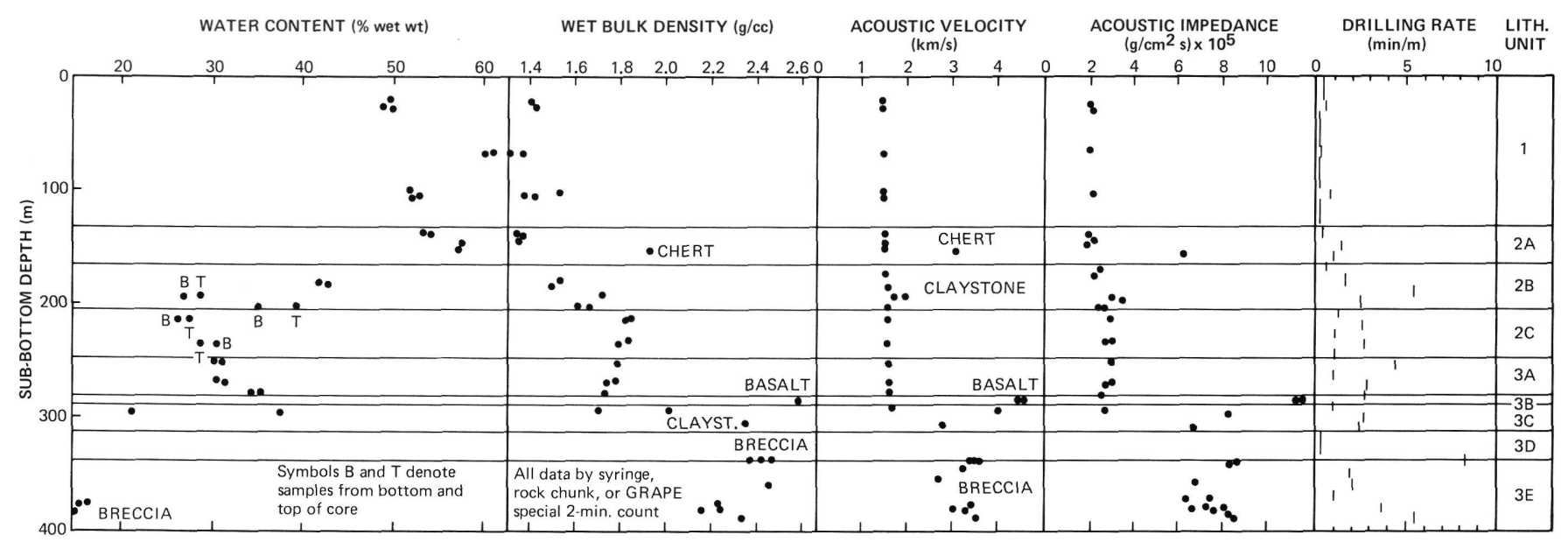

Figure 11. Physical properties at Site 385.

CCD during the very early part of the Danian stage; contrary to previous interpretations (Worsley, 1974). Cores 12 and 13 consist of marly ooze containing species assemblages of middle to late Maestrichtian age. The nannoplankton record suggests a somewhat neritic environmental habitat during this time.

This paleontologic information, plus the local occurrence of agglutinated foraminifers in Cores 14 through 16, suggests the following:

1) Volcanogenic sedimentation below the CCD during an unspecified interval prior to the middle Maestrichtian.

2) A deepening of the CCD during the Maestrichtian, especially in the latter part of this stage.

3) A shoaling CCD in the earliest Danian followed by deposition of non-calcareous radiolarian-bearing hemipelagic clay during the Paleogene, and interspersed with major intervals of non-deposition.

4) Deposition of gray barren clay with some seamount detritus during the Neogene.

5) Deposition of a thin ( $\$ 20 \mathrm{~cm}$ layer) of Holocene nannofossil-foraminifer ooze due to CCD depression.

\section{Cenozoic Foraminifers}

Cenozoic foraminifers were recovered in Cores 1 and 11 at Site 385. At the top of Core 1 is an approximately 20 -cm-thick unit of brown foraminifer ooze which contains a probable Recent warm-water assemblage that includes species such as Globorotalia menardii, Sphaeroidinella dehiscens, Pulleniatina obliquiloculata, pink Globigerinoides rubra, and others. Although foraminifers are the chief component of this sediment, they show evidence that some dissolution is taking place at the depth of the present coring site. The core-catcher sample from this core, a gray, sandy clay, yielded a very sparse assemblage of cool-water species that contains Neogloboquadrina pachyderma, Globorotalia inflata, $N$. dutertrei (small specimens), Globigerina bulloides, and Globigerinoides sacculifera. The section below Core 1 is a non-calcareous radiolarian facies.
A calcareous layer at 148 to $150 \mathrm{~cm}$ in Core 11 , Section 2, contains a well-preserved assemblage of Paleocene (early Danian) age. The assemblage consists of "Globorotalia" pseudobulloides, a globigerinid morphotype of " $G$." pseudobulloides (= Globigerina danica Bang?) which is probably ancestral to Subbotina triloculinoides, common chiloguembelinids, and a few per cent of reworked Maestrichtian forms. Placement in the lower part of Zone P.1 is indicated. This assemblage is similar in all respects to coeval assemblages of the lower Danian at Site 384.

\section{Mesozoic Foraminifers}

Uppermost Maestrichtian foraminifers, including Abathomphalus mayaroensis, occur in Sample 11-2, $148-150 \mathrm{~cm}$. However, they appear to be abraded, the fauna lacks many species that normally occur, and these Cretaceous specimens constitute a numeric minority of the fauna in the sample, which is dominated by Paleocene forms. In addition, nannofossils of the sample indicate the lowermost Paleocene. Consequently, it appears that the Cretaceous forms are reworked, physically or biologically, from Cretaceous in proximity below.

Core 12 recovered only 2.15 meters of gray-brown and light greenish gray silty clay and marly nannofossil ooze. Residues from the clays are very small, and the foraminifers in them are entirely agglutinates and benthic hyaline forms. The agglutinates appear to have more calcareous cement in the gray-brown than in the greenish gray layers, whereas the hyalines appear to be more common in the greenish gray and gray layers. Layers of all colors, especially including the light gray layers of apparent promise, were sampled but no planktonic forms were recovered.

Core 13 was cut after a 9.7-meter uncored interval and recovered 5.1 meters of calcareous silty clay like that of Core 12. There was loose material in the periphery of the liner and individual layers were bent, suggesting disturbance and possible mixing or contamination by drilling fluid. With one exception the 
results of samples from this core were like those of Core 12. The exception, a sample from a light gray layer at $13-3,25-27 \mathrm{~cm}$, yielded a residue with abundant planktonics of the $A$. mayaroensis Zone and a sparse assemblage of Upper Cretaceous benthonics. On shipboard it was thought that this sample was a result of redrilling cavings from the top of Core 12, but nannofossils do not support this inference.

Below Core 13 the clays are darker and are interbedded with increasingly volcanogenic layers. The benthic hyaline foraminifers disappear. The agglutinates lose most of their calcareous cement and become the tiny fauna that Krasheninnikov reported from Leg 20 (1973) and Leg 27 (1975). The temporal significance of these is most questionable, for they are, insofar as known, longranging forms.

Thus the correlation of Mesozoic cores is based upon two samples, $11-2,148-150 \mathrm{~cm}$ and $13-3,25-27 \mathrm{~cm}$. Of these the first appears to be a Paleocene sample with reworked Mesozoic forms, and the second is conspicuous by its contrast with all other Mesozoic samples, none of which contain planktonic foraminifers. The latter sample is assigned to the $A$. mayaroensis Zone of the upper Maestrichtian.

\section{Nannofossils}

At Site 385 , only 4 out of 24 cores contain nannofossils. At the top of Core 1, a 20-cm-thick nannofossilforaminiferal ooze was recovered, containing abundant nannofossils of the latest Pleistocene or Holocene epochs. A few reworked Cretaceous forms are also present. The remainder of Core 1 and all cores down to Core 11 are barren of calcareous nannoplankton. The bottom $20 \mathrm{~cm}$ of Core $11(11-2,130-150 \mathrm{~cm})$ contains a poorly preserved early Danian assemblage (Cruciplacolithus tenuis Zone). The absence of Cruciplacolithus tenuis tenuis in the lower $10 \mathrm{~cm}$ of this interval indicates presence of the earliest $C$. tenuis Zone.

Core 12 and the first two sections of Core 13 contain moderately to strongly corroded assemblages with abundant Micula mura of latest Maestrichtian age. No Nephrolithus frequens were encountered. Etched nannoliths of the middle Maestrichtian are present down to Sample 13, CC. The cores below are barren.

\section{Palynomorphs}

Five samples from Cores 12 through 16 were examined for dinoflagellates and sporomorphs in an attempt to determine ages in the upper part of the volcanogenic sediments. All samples were barren (D. Habib, personal communication, 1976).

\section{Radiolarians}

The radiolarian zonations are given in Figure 5.

\section{SEDIMENT ACCUMULATION RATES}

Accumulation rates of the volcanogenic sediments (Unit 3) in the lower part of the borehole are virtually unknown. The only fauna observed in these sediments consists of tiny, long-ranging agglutinated foraminifers, possibly of ?Coniacian age. However, the volcanogenic sediments probably accumulated at an average rate comparable to that of similar sediments drilled at Site 382 on the flank of Nashville Seamount, about 30 $\mathrm{m} / \mathrm{m}$.y. If this rate is reasonably accurate, then a sharp drop in accumulation rate, or an unconformity, is implied near the top of the volcanogenic sediments (Figure 12).

The overlying clays and oozes of lithologic Unit 2 seem to have accumulated nearly continuously at rates of about 3 to $10 \mathrm{~m} / \mathrm{m}$.y. An unconformity truncates the top of this unit, and the hiatus extends from ?upper Oligocene to middle Eocene. The age of the hiatus suggests that it was caused by the same episode of intensified abyssal circulation that eroded large volumes of sediment along the lower continental rise of the eastern United States (e.g., Site 105).

Accumulation rates above the unconformity are poorly documented because of intermittent coring and an impoverished fossil record. However, rapid accumulation $(\sim 50 \mathrm{~m} / \mathrm{m} . \mathrm{y}$.) is indicated during the late Oligocene. Neogene sediments either accumulated at much slower rates or are interrupted by undetected hiatuses.

\section{CORRELATION OF SEISMIC PROFILE WITH DRILLING RESULTS}

Three primary acoustic intervals are recognized in the Challenger seismic profiles across Site 385 (Figures $4,13)$.

Acoustic interval 1 is the topmost interval and is acoustically non-laminated or very weakly laminated. On the northern side of the seamount, the interval dips beneath the highly reflective turbidites of the Sohm Abyssal Plain. The interval crops out where it is draped around the base of Vogel Seamount and other seamounts in the Kelvin chain. Within $100 \mathrm{~km}$ of Site 385, interval thickness varies from zero on the middle and upper flanks of the Kelvin Seamounts up to $0.6 \mathrm{sec}$ away from the seamounts. At Site 385, the interval thickness is about $0.20 \mathrm{sec}$. On the Challenger profile approaching Vogel Seamount from the north (Figure 4), acoustic interval 1 varies between 0.1 and $0.2 \mathrm{sec}$ thickness, and the overlying turbidites are 0.2 to $0.4 \mathrm{sec}$ thick.

Acoustic interval 2 is non-laminated or weakly laminated with a thickness of zero to $0.25 \mathrm{sec}$. This unit does not crop out, and it is separated from interval 1 by a prominent reflector (Horizon $A^{\mathrm{C}}$ ) which can be traced beneath the Sohm Plain (Figure 4). The thickness of interval 2 is about $0.16 \mathrm{sec}$ at Site 385 .

Acoustic interval 3 has an upper surface which is smooth to gently undulating and creates a strong, reverberant echo. Interval 3 is an extension of the "acoustic basement" of Vogel Seamount and forms a skirt-like apron around the seamount, becoming more nearly horizontal away from the seamount. Although the interval is acoustically opaque near Site $\mathbf{3 8 5}$ and on the seamount itself, it merges laterally with a series of reflectors which lie well above probable basaltic basement beneath the Sohm Abyssal Plain (Figure 4).

Under this part of the Sohm Abyssal Plain, a poorly defined reflector lies in an acoustically nonlaminated interval between probable oceanic basement and the 


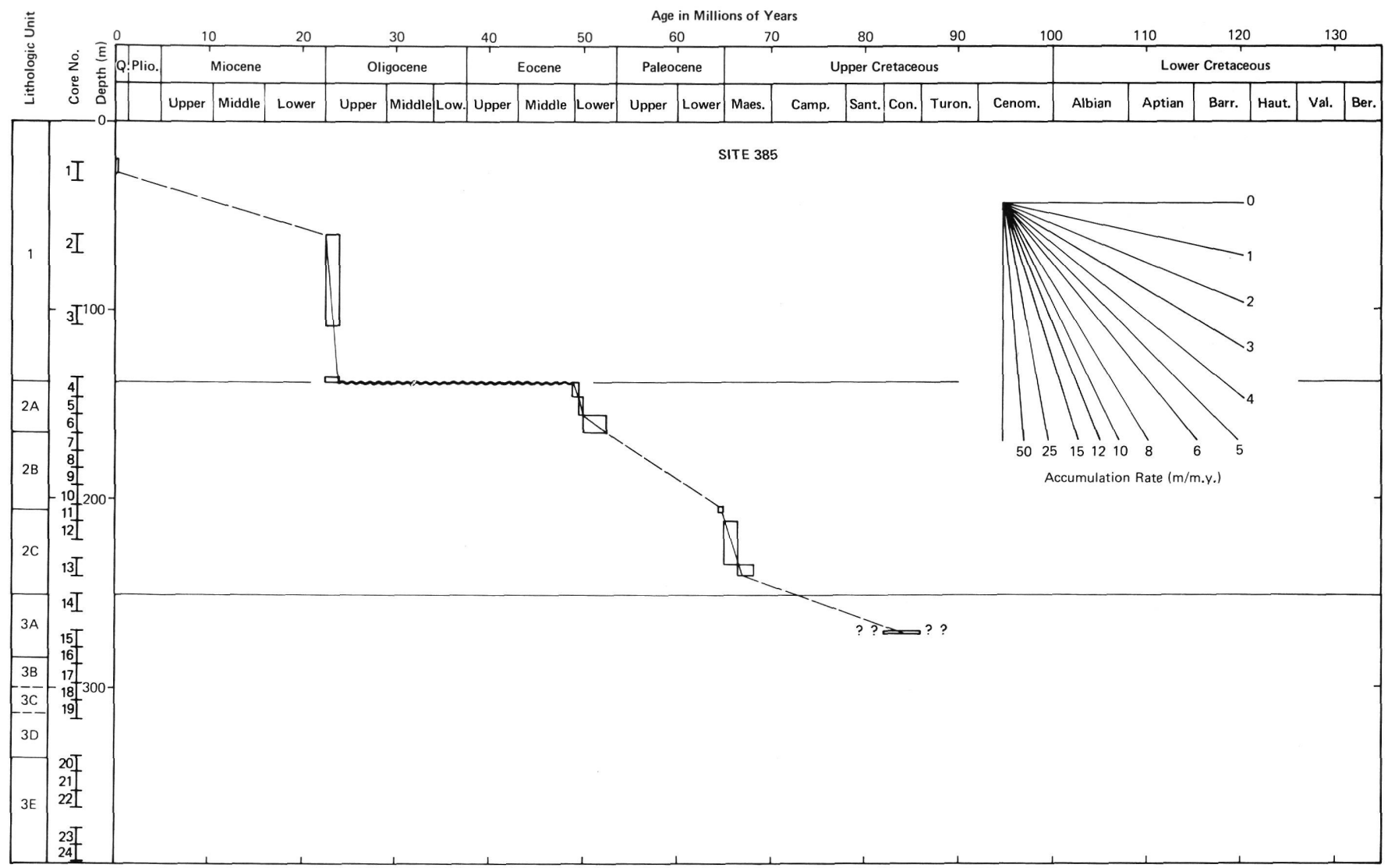

Figure 12. Sediment accumulation rates, Site 385.

laterally equivalent reflectors of interval 3. Its stratigraphic position suggests the reflector may be Horizon $\beta$, although seismic continuity with Horizon $\beta$ south of the seamounts has not been established.

Presumed oceanic basement lies at depths of 7.6 to $7.9 \mathrm{sec}$ beneath the Sohm Abyssal Plain north of Vogel Seamount; thus at Site 385 , the original basaltic crust is probably at least $1.3 \mathrm{sec}(\sim 1350 \mathrm{~m})$ below the sea floor.

The correlation of acoustic intervals 1, 2, and 3 with lithofacies can be reasonably inferred (Figure 13); the primary limitation is the imprecise determination of reflection times. Acoustic interval 1 correlates with clays and radiolarian clays ranging in age from Pleistocene to upper-lower Eocene (approximately correlating with lithologic Units 1 and 2A). Sohm turbidites of inferred Pleistocene and ?Pliocene age are the lateral equivalent of the upper part of this interval.

The prominent reflecting horizon separating intervals 1 and 2 correlates in time and lithofacies (upper-lower Eocene chert) with Horizon $A^{c}$ (Tucholke, this volume) which is widely observed in seismic profiles in the western North Atlantic between the Puerto RicoBahama region and the New England seamounts. The correlation of upper-lower Eocene cherts (Site 385) and siliceous limestones/chert (Site 384) with the prominent seismic reflector north of the New England seamount chain suggests that Horizon $A^{C}$ extends at least as far north as the Grand Banks continental rise. However, the thick, reflective turbidites under the Sohm Abyssal Plain often mask or confused identification of Horizon $A^{c}$ and thus have prohibited seismically tracing the horizon to the north.

The detailed lithofacies of the Horizon $A^{c}$ cherts at Site 385 cannot be determined because of poor core recovery in this interval. Fragments of chert were recovered in Cores 6 and 7, but changes in drilling rates suggest that the cherts are probably confined to an interval several meters thick located in the lower part of Core 5 (153-156 m) with several more thin layers in Core 6. Sporadic fast/slow drilling suggests that the chert is composed of closely spaced, brittle stringers. Drilling rates increased to normal in Core 7, and the chert fragments recovered in this core presumably caved from a higher level. Assuming the shallowest cherts occur near 154 meters sub-bottom, the calculated in-situ velocity for sediments within acoustic interval 1 is 1.54 $\mathrm{km} / \mathrm{sec}$ (Figures 13,14).

Acoustic interval 2 corresponds to zeolitic clay, marly nannofossil ooze, and banded vitric clays of upperlower Eocene to Maestrichtian age (lithogic Sub-units $2 \mathrm{~B}$ through $3 \mathrm{~A}$ ). The bottom of this interval is a thin basalt layer which is probably a sill and part of which was recovered in the core catcher of Core 16 . Based on drilling rates, the basalt was first encountered 


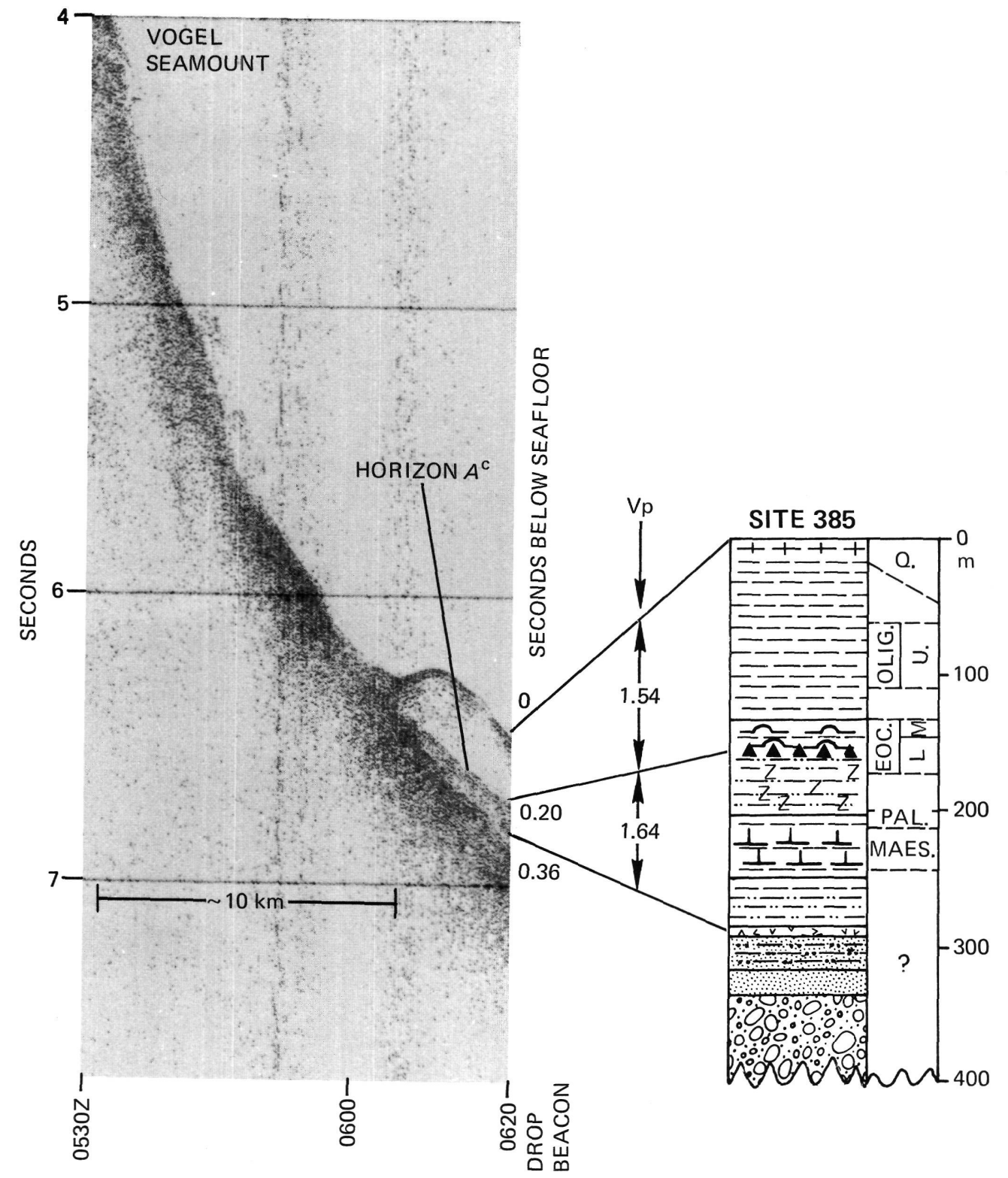

NANNO-FORAM OOZE

CLAY

RADIOLARIAN CLAY AND OOZE

CHERT

ZEOLITIC SILTY CLAY

MARLY NANNO OOZE

VITRIC SILTY CLAY

AND CLAY; BASALT

VITRIC CLAYEY SILT

BASALTIC SILTY SAND

VOLCANICLASTIC BRECCIA

Figure 13. Glomar Challenger profile approaching Site 385 and correlation with the drilled section. Location of profile is shown in Figure 3.

about 285 meters sub-bottom; thus the calculated in-situ velocity for acoustic interval 2 is about $1.64 \mathrm{~km} / \mathrm{sec}$ (Figures 13,14).

Core 17 returned empty, but drilling characteristics and the nature of deeper cores suggest that the core penetrated primarily sand- to cobble-size basaltic debris. This material is locally cemented into breccia and is interbedded with clay and silt, constituting acoustic interval 3. This interval continues from about 285 meters to below the level of deepest penetration $(392.9 \mathrm{~m})$. Velocity measurements on samples from interval 3 (volcanogenic clays, volcaniclastic breccias, and basalt) gave values ranging from 1.72 to $4.44 \mathrm{~km} / \mathrm{sec}$ (Figure 14), but high-impedance basalt clearly forms the acoustic contrast responsible for the reflector at the top of the interval.

\section{SUMMARY AND CONCLUSIONS}

Site 385 was drilled in 4956 meters water depth on the north flank of Vogel Seamount and penetrated 392.9 meters. The total length of the cored section was 227.6 meters and 63.43 meters $(27.9 \%)$ were recovered. The poor core recovery is thought to be caused by penetration of unconsolidated volcanic sands and gravel which were mostly not retained by the dog-type core catchers.

Vogel Seamount lies about one-third of the way up the New England seamount chain, about $450 \mathrm{~km}$ northwest of Site 382 on the flank of Nashville Seamount. In our approach to Vogel Seamount from the north, we obtained a high-quality seismic record which clearly showed Horizon $A^{C}$ beneath the southern portion of the Sohm Abyssal Plain. The horizon could be traced part 


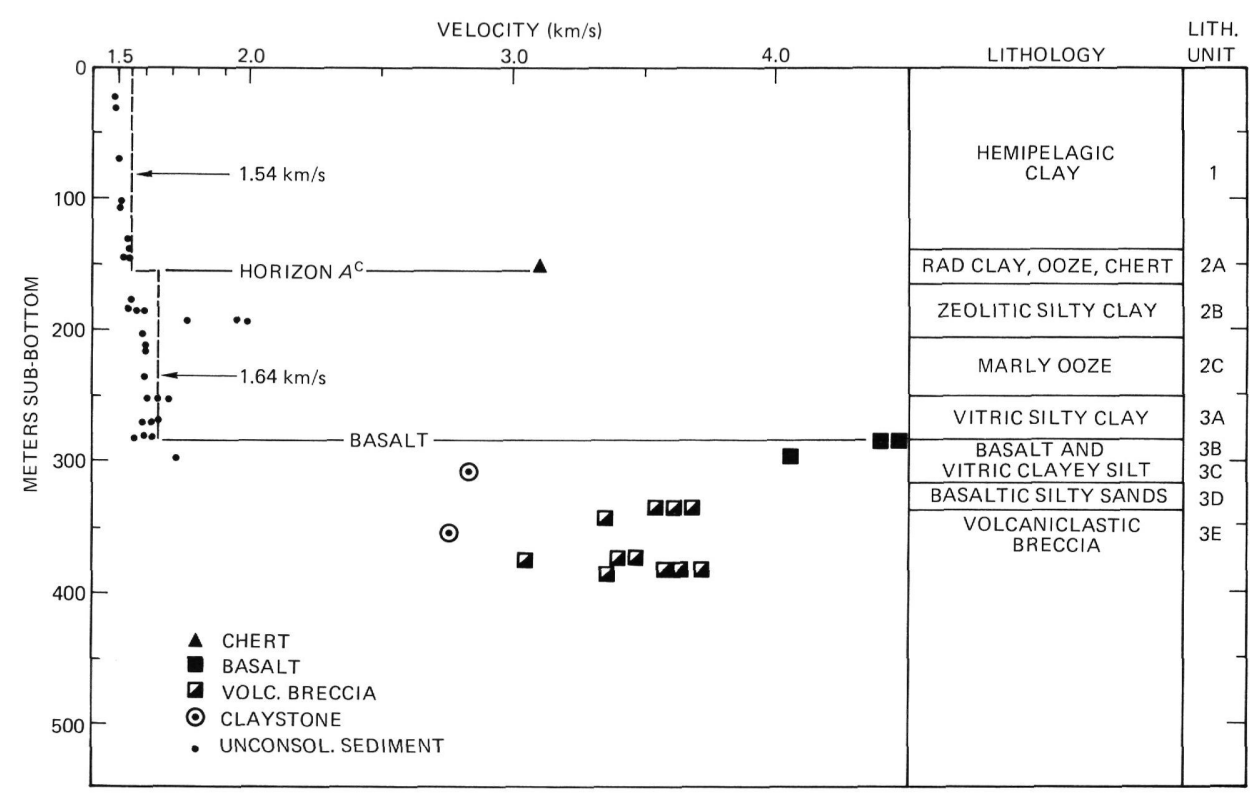

Figure 14. Measured velocities for sediments and rocks using the Hamilton Frame velocimeter (symbols) and interval velocities calculated from correlation with seismic profile (dashed lines) at Site 385.

way up the deep flank of the seamount within an acoustically non-laminated section of sediment blanketing the seamount's base. Site 385 was chosen at a location midway up this section, about $17 \mathrm{~km}$ from the crest of the seamount.

The seismic record shows the following acoustic intervals at the site (from top to bottom):

(a) An acoustically non-laminated layer lapping onto the base of the seamount and about $0.20 \mathrm{sec}$ thick at Site 385.

(b) A single reflective horizon, similarly lapping onto the base of the seamount, which correlates with Horizon $A^{c}$ and can be traced northward from the site.

(c) A thin non-laminated interval below Horizon $A^{c}$, overlying

(d) The acoustically opaque "archipelagic apron" of Vogel Seamount.

The objectives in drilling at this location were to date the time of volcanism, obtain fresh basaltic material for age dating and other analyses, confirm the age and lithofacies of Horizon $A^{c}$, and investigate the age and nature of the non-laminated sediment layer surrounding the seamount. The New England seamounts have been cited as a linear volcanic chain which may have been created as the North Atlantic lithosphere drifted slowly west-northwest across a mantle plume or hot spot. This hypothesis predicts an age gradient along the seamount chain, wherein the most youthful volcanism would occur at the eastern end of the chain. Specifically, the model of Morgan (personal communication, 1976) has the North America plate moving over the sublithospheric mantle at a rate of about $0.38 \% \mathrm{~m}$.y. about a pole located at $60.7^{\circ} \mathrm{N}, 57.8^{\circ} \mathrm{E}$ during Cretaceous times. Site 385, in conjunction with Site 382 drilled near Nashville Seamount, was designed as a first step in testing the hot-spot hypothesis.

\section{Lithologic Summary}

The section cored (Figure 5) consists of upper Oligocene to Holocene hemipelagic gray clay $(0-138 \mathrm{~m})$, upper-lower Eocene radiolarian clay and ooze with basal cherts (138-165 m), zeolitic silty clay dated as Paleocene to lower Eocene (165-206 m); earliest Danian and Maestrichtian marly ooze (206-251 m), and volcanogenic sediments certainly predating the middle Maestrichtian below $251 \mathrm{~m}$. An aphanitic tholeiite still dated at $21 \pm 3$ m.y.B.P. was cored at 283 meters; vesicular alkali basalt fragments occur in volcaniclastic breccias below about 338 meters.

The upper-lower Eocene cherts recovered in Cores 6 and 7 correlate with Horizon $A^{C}$ but probably were not recovered in place. Hard drilling was encountered in Core 5, about 7 meters into the core $(153 \mathrm{~m}$ sub-bottom), but no chert was found in the 5 meters of sediment recovered. Core 6 encountered hard drilling in thin bands and recovered only $5 \mathrm{~cm}$ of chert. Core 7 was drilled without any hard layers being felt, but recovered no sediment except $10 \mathrm{~cm}$ of clay and chert chips in the core catcher. Thus it appears that Horizon $A^{c}$ cherts occur in situ at the level of Cores 5 and 6 , but were recovered mostly as hole cavings in Cores 6 and 7. It is felt that these chert cavings plugged the core catcher and prevented recovery of further sediment in Cores 6 and 7 . The drilling record indicates that Horizon $A^{c}$ consists of thin $(<0.5 \mathrm{~m})$ chert stringers interbedded with softer material and extending over a depth interval of about 12 $\mathrm{m}(153-165 \mathrm{~m})$.

\section{Volcanic History of Vogel Seamount}

Volcanogenic sediments cored below 251 meters subbottom are summarized in the Graphic Hole Summary (Figure 5). The deepest volcanic material penetrated is a 
volcaniclastic breccia very similar to that recovered at Site 382 near Nashville Seamount. As at Nashville, it is believed to represent a time of strong eruptive activity when volcanic debris was displaced from the crest and flanks of Vogel Seamount and rapidly was redeposited on the lower flanks of the volcanogenic apron. The emplacement probably coincided with eruptions, although pre-existing volcanic debris was undoubtedly incorporated in the debris flows, since the latter contain clasts of varying composition, vesicularity, and degree of alteration. The breccia is overlain by finer-grained volcanic debris probably derived from the seamount, perhaps with contributions from nearby Rehoboth Seamount. One thin $(0.18 \mathrm{~m})$ layer of aphanitic basalt was cored at 283.36 meters within the volcanogenic unit. Although its compositional and textural characteristics suggest the unit could be either an intrusive sill or an extrusive flow, a radiometric date of $21.0 \pm 3$ m.y.B.P. shows that it is a sill of much younger age than the seamount (Houghton et al., this volume).

Unfortunately, the volcanogenic unit is unfossiliferous except for a few long-ranging benthic foraminifers, possibly of Coniacian/Santonian age, and the deepest reliable dates in the hole (middle Maestrichtian) are for the marly ooze above the volcanogenic unit.

Up to 87 meters of volcanogenic vitric silty clay, sand, and coarse volcanic detritus may be present between the marly ooze and the basaltic breccia. Analogy with Site 382 suggests this volcanogenic material was rapidly deposited (the rate at Site 382 cannot be less than about $30 \mathrm{~m} / \mathrm{m}$.y.), and it is unlikely to represent much more than a few million years in time. Because the most reliable radiometric date, $91.2 \pm 3$ m.y.B.P. (Houghton et al., this volume) makes the basalt breccia some $23 \mathrm{~m}$.y. older than the marly ooze, one or more hiatuses probably exist within the volcanogenic sediments or between the volcanogenic sediments and the marly ooze (an even longer hiatus is known to exist at the top of the volcanogenic sediment at Site 382). Thus, at least parts of the volcanogenic sediments are likely to be substantially older than midMaestrichtian; they may be Coniacian/Santonian as is tentatively indicated by long-ranging benthic foraminifers. Combining all information, our best estimate for the main constructional activity at Vogel Seamount is 87 to 92 m.y.B.P. While this appears slightly older than the 80 to 85 m.y.B.P. age inferred for Nashville Seamount, the age difference may not be significant. We can exclude motion over a hot spot at $\sim 1 \mathrm{~cm} / \mathrm{yr}$, but a $4 \mathrm{~cm} / \mathrm{yr}$ rate suggested by $\mathrm{W}$. J. Morgan (personal communication, 1976) can be accommodated by the drill-hole data at Sites 382 and 385 . Coeval volcanism along the entire chain around 85 to 90 m.y.B.P. is also allowed, although such a model leaves unexplained the existence of the older White Mountain Magma Series to the northwest and the younger Corner Seamounts southeast of the New England chain, if they are indeed genetically related to the chain (Vogt and Tucholke, this volume).

Chemically the breccia fragments represent highly alkalic basalts enriched in the LIL elements; the Vogel and Nashville breccias are chemically similar, and in terms of the rare earth and other immobile elements, the seamount basalts exhibit some similarity to basalts of the White Mountain Magma Series (Houghton, this volume).

The original summit depth of Vogel Seamount cannot be inferred as easily as that of Nashville (Site 382) because no shallow-water fossils were recovered at Site 385. However, the highly vesicular basalt clasts in the breccia representing the earliest volcanic event cored at Vogel Seamount again are indicative of extrusion of source rock in water depths less than 1000 meters. Furthermore, adjacent Rehoboth Seamount has a flat, guyot-like summit presently 1269 meters deep and some 943 meters shallower than Vogel Seamount. If both seamounts formed at the same time and have not subsided differentially, the top of Vogel Seamount would have been about 943 meters deep at the time of its final activity. Evidently the age of the breccia fragments $(91.2 \pm 3$ m.y. Houghton et al., this volume) represents a time when the seamount had already been constructed to essentially its present height. Although the time necessary for construction is unknown, it is unlikely to be more than a few million years (see Vogt and Tucholke, this volume).

\section{Sedimentation History Subsequent to Volcanism}

Average sedimentation rates appear to have been relatively uniform in the mid-Maestrichtian to lower Eocene section cored at Site 385 (Figure 12), even though there is an upward change from marly ooze to radiolarian clays. The pre-Maestrichtian volcanogenics have little carbonate, either detrital or biogenic, while marly nannofossil oozes are common in the Maestrichtian to lowermost Paleocene sediments. If the volcanogenic rate of accumulation was not so high as to mask carbonate production before the Maestrichtian, it appears that the pre-Maestrichtian CCD must have been relatively high and that deposition of the Maestrichtian marly oozes occurred during a sharp Late Cretaceous depression of the CCD. If the age/depth curve for the central north Atlantic was approximately time-invariant during evolution of the Cretaceous North Atlantic sea floor, then the CCD must have been depressed to at least 5300 meters in the Maestrichtian and earliest Paleocene (Tucholke and Vogt, this volume). This observation matches apparent variations in carbonate sedimentation/CCD depths determined at Site 386 and 387 , but it is in direct opposition to postulated sharp rises of the CCD to near sea level at the Cretaceous/ Tertiary boundary (Worsley, 1974; Ramsay, 1974). A sharp rise in the CCD is indicated in the early Paleocene, however, near the end of nannofossil Zone NP 1 (64 m.y.), when carbonate values dropped abruptly and zeolitic silty clays were deposited.

The Paleocene to earliest Eocene zeolitic clays were apparently deposited well below the CCD, at rates of 3-4 $\mathrm{m} / \mathrm{m}$.y. Manganese stains and the growth of authigenic zeolites in the sediments support this interpretation of low accumulation rates. 
The lower Eocene section containing the Horizon $A^{c}$ cherts is highly siliceous, containing an average of about $40 \%$ radiolarians and a few per cent of diatoms. This siliceous section persists into the middle Eocene, and in conjunction with data from Sites $6,7,8,9$, and 384, attests to the very widespread production of siliceous organisms at least during early and middle Eocene time in the western North Atlantic. The mechanism responsible for providing necessary nutrients for this $8+$ m.y. "bloom" still is not clearly understood. It has been suggested several times that the silica could have been provided by extensive Eocene volcanic activity, but whether this mechanism could provide other essential nutrients such as phosphorous is uncertain. At least, the "bloom" of siliceous organisms was roughly contemporaneous (actually slightly later) than the peak ash production in the Thulean province to the northeast (see Tucholke and Vogt, this volume). Massive upwelling in the western basin is another mechanism that has been proposed to explain the "bloom," but the circulation changes that could create such upwelling in a region which has classically been envisioned as a central gyre or marine desert are uncertain.

A major disconformity was encountered in the sedimentary record at Site 385, extending from the lower middle Eocene to the uppermost Oligocene. Hiatuses or low accumulation rates also are present in the lower Miocene to the Pliocene (Figure 12). It is likely that these are mostly related to periods of erosion or non-deposition by abyssal currents. The Eocene/Oligocene hiatus correlates in time with the major event of erosion by bottom currents along the continental margin to the west; however, the relationship of the bottom currents at Vogel Seamount to the major deep flow along the Eocene/Oligocene continental margin is still unclear.

The virtual absence of fossil carbonate material in the post-early Paleocene record at Site 385 indicates sediment deposition below the range of CCD fluctuations throughout most of the Tertiary. A small sample of Quaternary ooze in Core 1 (probably near surface) suggests at least one cycle of CCD depression within the last 1.8 million years.

\section{REFERENCES}

Dapples, E. C., 1967. Diagenesis of sandstone. In Larsen, G. and Chilingar, G. V. (Eds.), Diagenesis in sediments: New York (Elsevier Press), 551 pp.

Dill, R. F., 1962. Sedimentary and erosional features of submarine canyon heads, Proc. First National Coastal and Shallow Water Research Conf., NSF and ONR p. 531.

Houghton, R. L. and Ballard, R. D., in preparation. Petrologic and tectonic observations of the New England Seamounts.

Krasheninnikov, V. A., 1973. Cretaceous benthonic foraminifera, Leg 20, Deep Sea Drilling Project.In Heezen, B. C., MacGregor, I.D., et al., Initial Reports of the Deep Sea Drilling Project, v. 20: Washington (U.S. Government Printing Office), p. 205-219. 1975. Upper Cretaceous benthonic agglutinated foraminifera, Leg 27 of the Deep Sea Drilling Project. In Veevers, J. J., Heirtzler, J. R., et al., Initial Reports of the Deep Sea Drilling Project, v. 27: Washington (U.S. Government Printing Office), p. 631-661.

Larsen, G. and Chilingar, G. V., 1967. Diagenesis in sediments: New York (Elsevier Press), 551 pp.

Ramsay, A., 1974. The distribution of carbonate in deep-sea sediments. In Hay, W. W. (Ed.), Studies in Paleoceanography: SEPM Spec. Publ. 20, p. 58-76.

Stevenson, F. J. and Cheng, C. N., 1972. Organic geochemistry of the Argentine Basin sediments: carbon-nitrogen relationships and Quaternary correlations, Geochim. Cosmochim. Acta, v. 36, p. 653-671.

Worsley, T., 1974. The Cretaceous-Tertiary boundary event in the ocean. In Hay, W. W. (Ed.), Studies in Paleoceanography: SEPM Spec. Publ. 20, p. 94-125. 


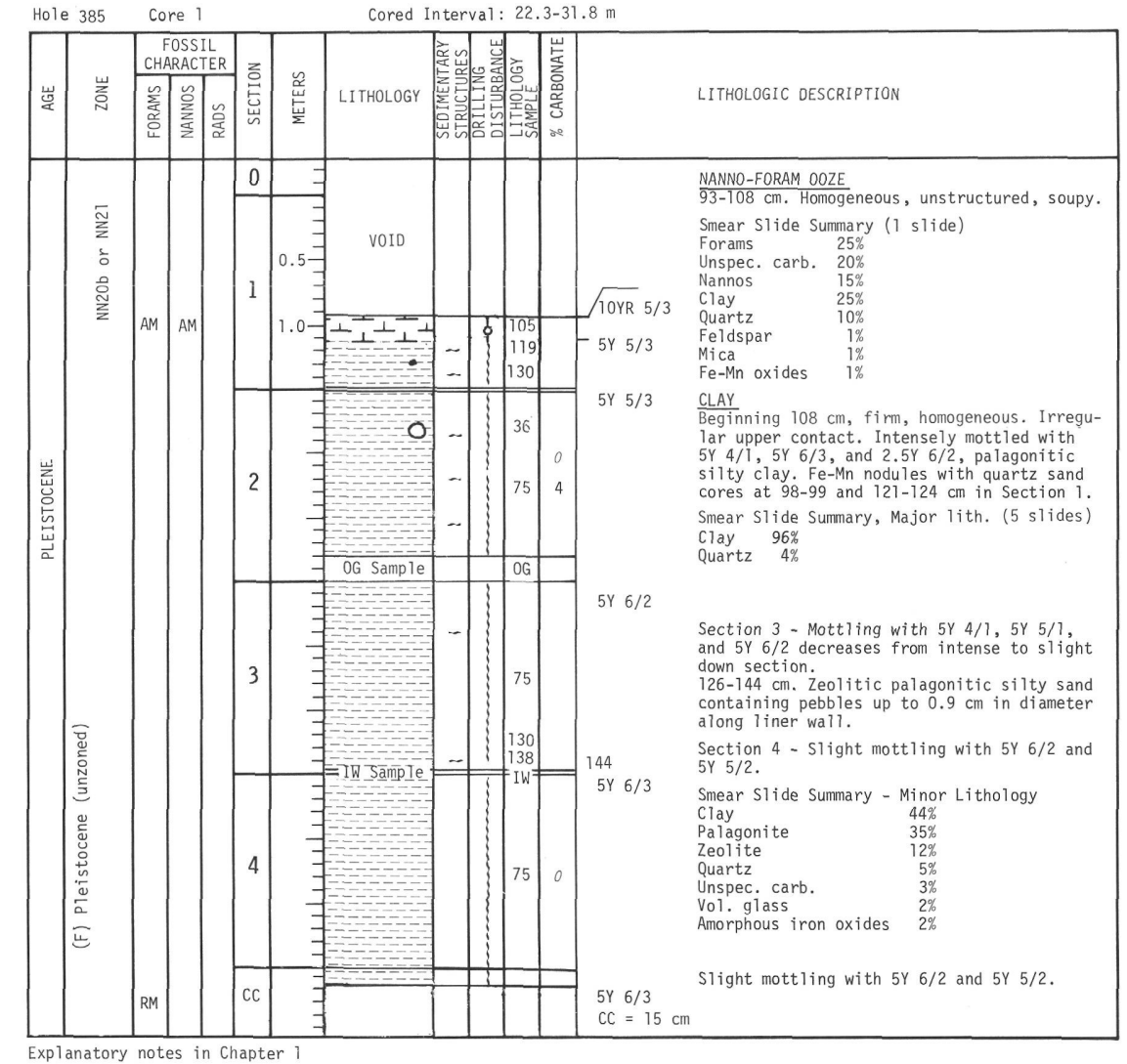

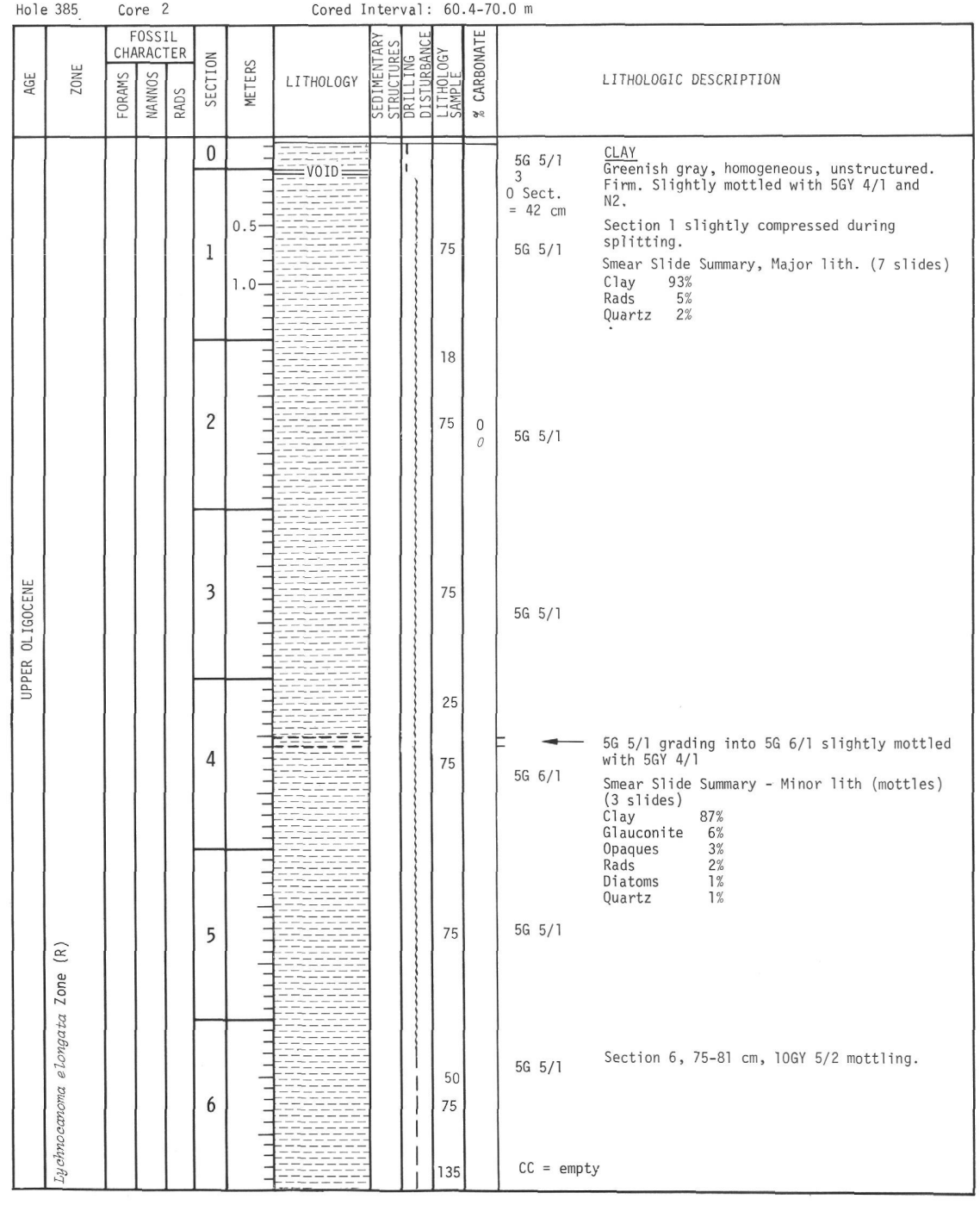




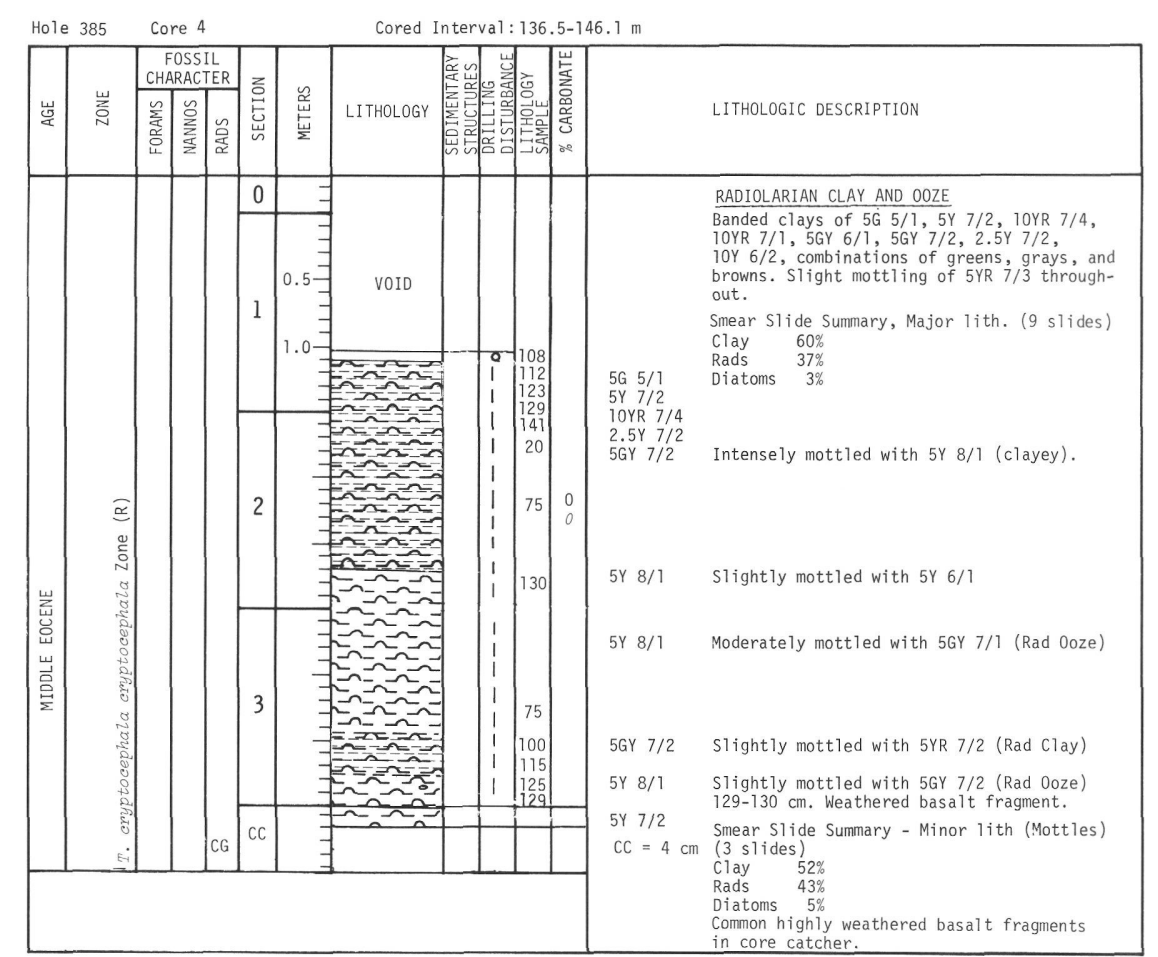




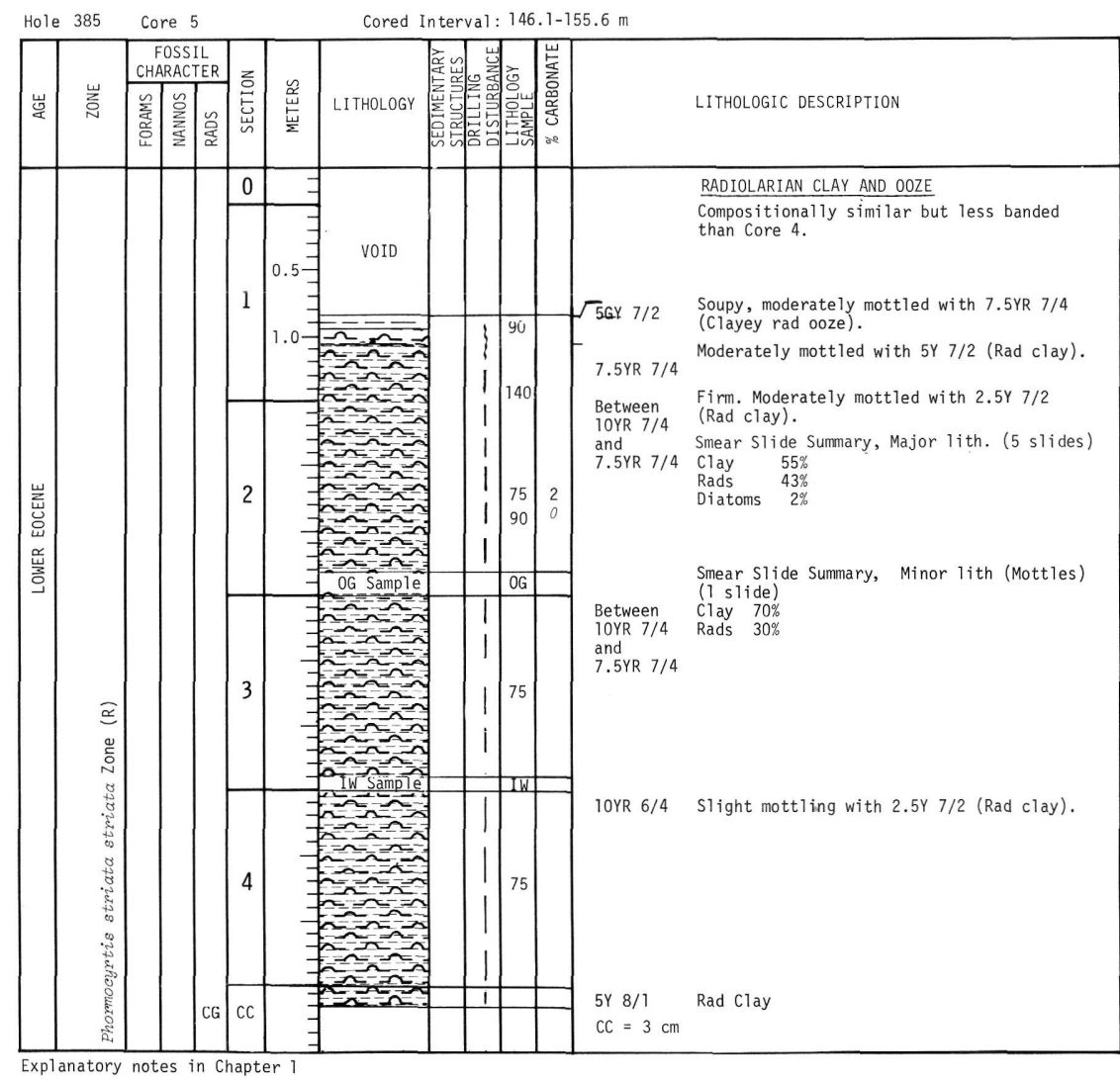

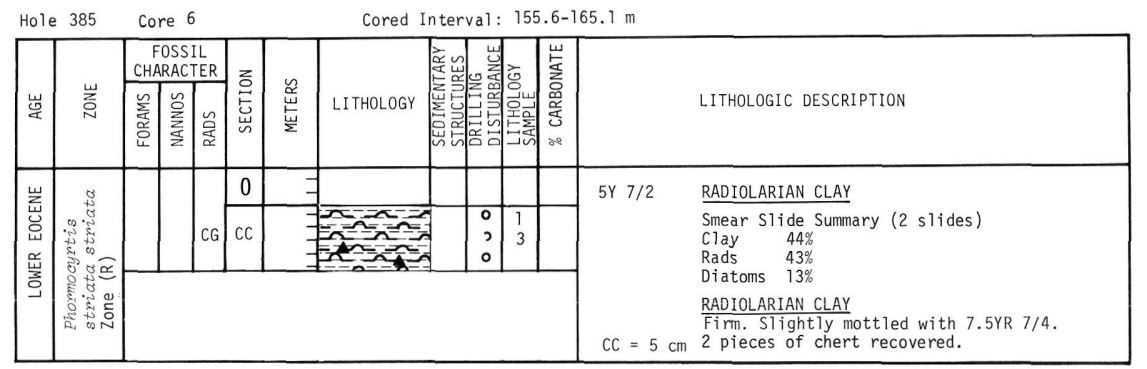

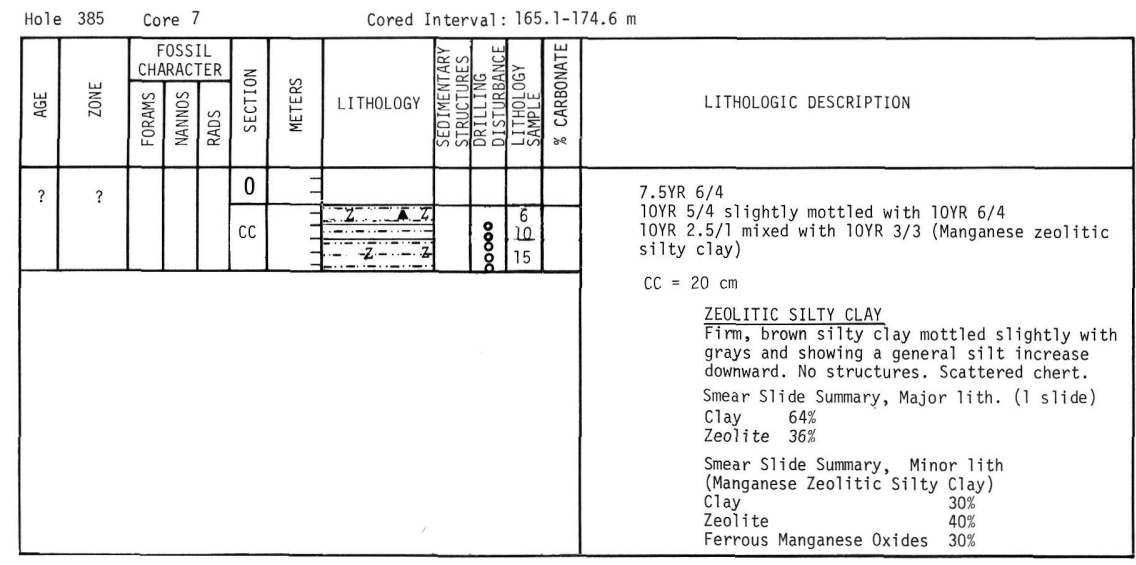





\begin{tabular}{|c|c|c|c|c|c|c|c|c|}
\hline \multicolumn{2}{|c|}{ tole 385} & $\begin{array}{l}\text { Core } 10 \\
\text { FossiL }\end{array}$ & \multicolumn{5}{|c|}{ Cored Interval: $193.4-4203.0 \mathrm{~m}$} & \multirow[b]{2}{*}{ LITHOLOGiC DESCRIPTION } \\
\hline 容 & 言 & 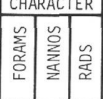 & 总 & 总 & LITHOLGY & 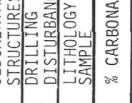 & & \\
\hline & ? & & 0 & & VOID & 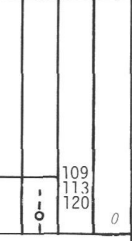 & $\begin{array}{l}\text { Tloyr } 6 / 4 \\
\text { L6G 5/1 }\end{array}$ &  \\
\hline & & & & & & & L5GY 5/1 & 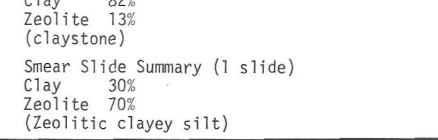 \\
\hline
\end{tabular}




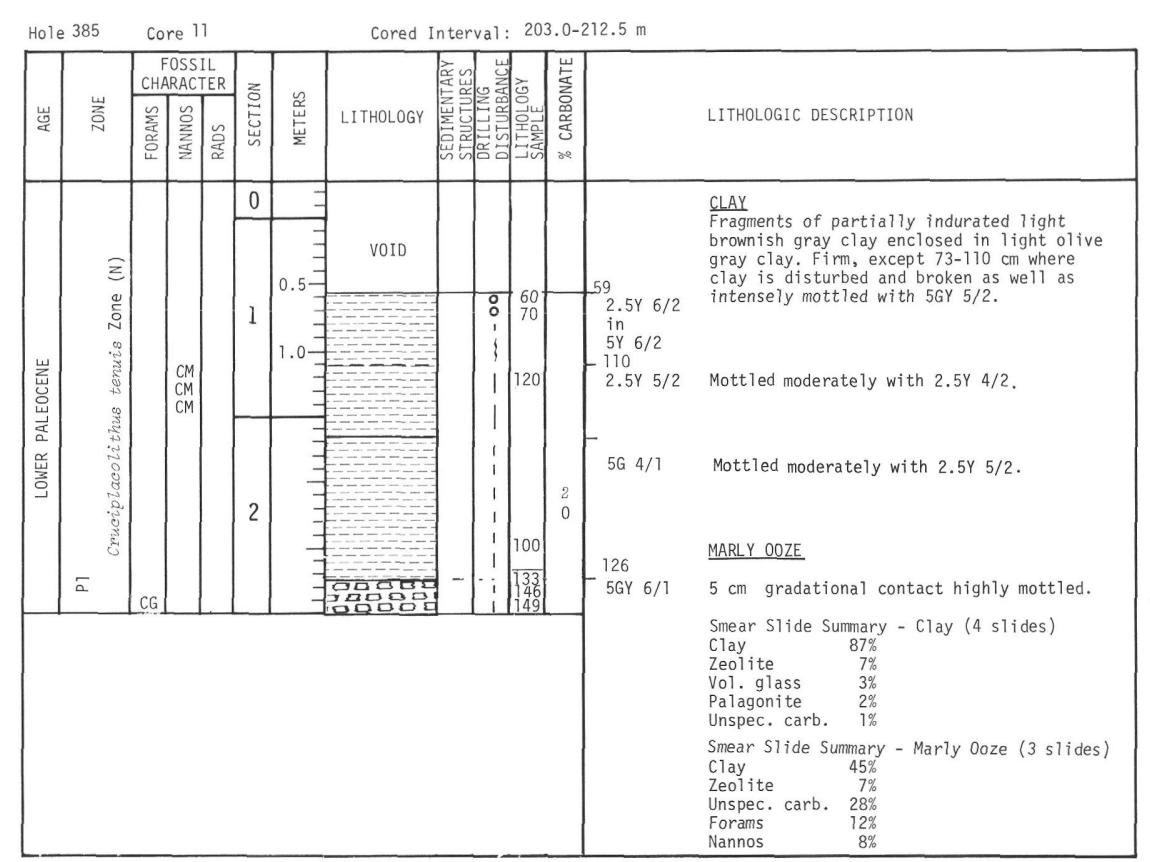

\begin{tabular}{|c|c|c|c|c|c|c|c|c|}
\hline \multicolumn{2}{|c|}{ Hole 385} & \multicolumn{2}{|c|}{$\begin{array}{c}\text { Core } 12 \\
\text { FosSIL }\end{array}$} & \multicolumn{4}{|c|}{ Cored Interval: $212.5-222.0 \mathrm{~m}$} & \multirow[b]{2}{*}{ LITHOLGGIC DESCRIPTION } \\
\hline 崖 & 訔 & & 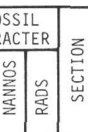 & 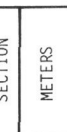 & LITHOLOGY & 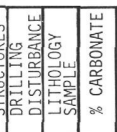 & & \\
\hline & 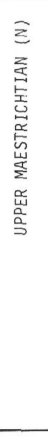 & & 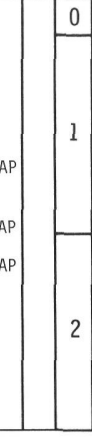 & 1 & 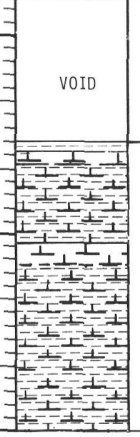 & 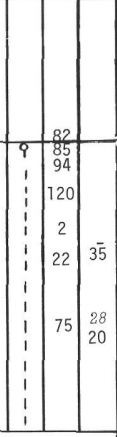 &  & 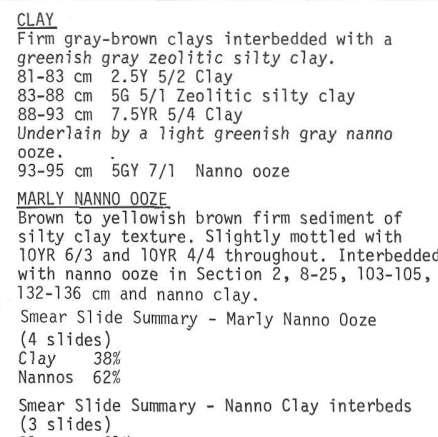 \\
\hline & & & & & & & & \\
\hline
\end{tabular}

Explanatory notes in Chapter 1

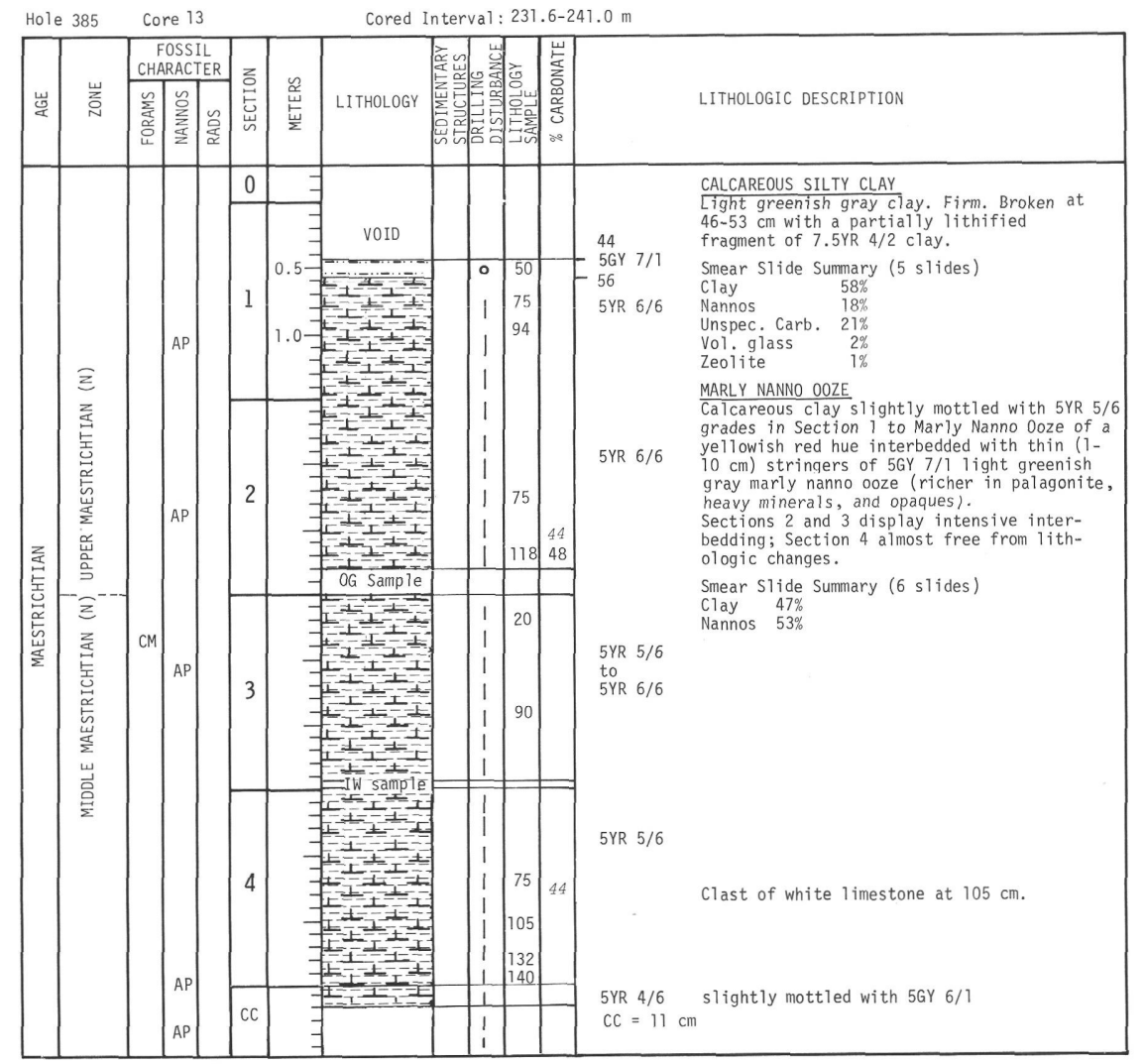





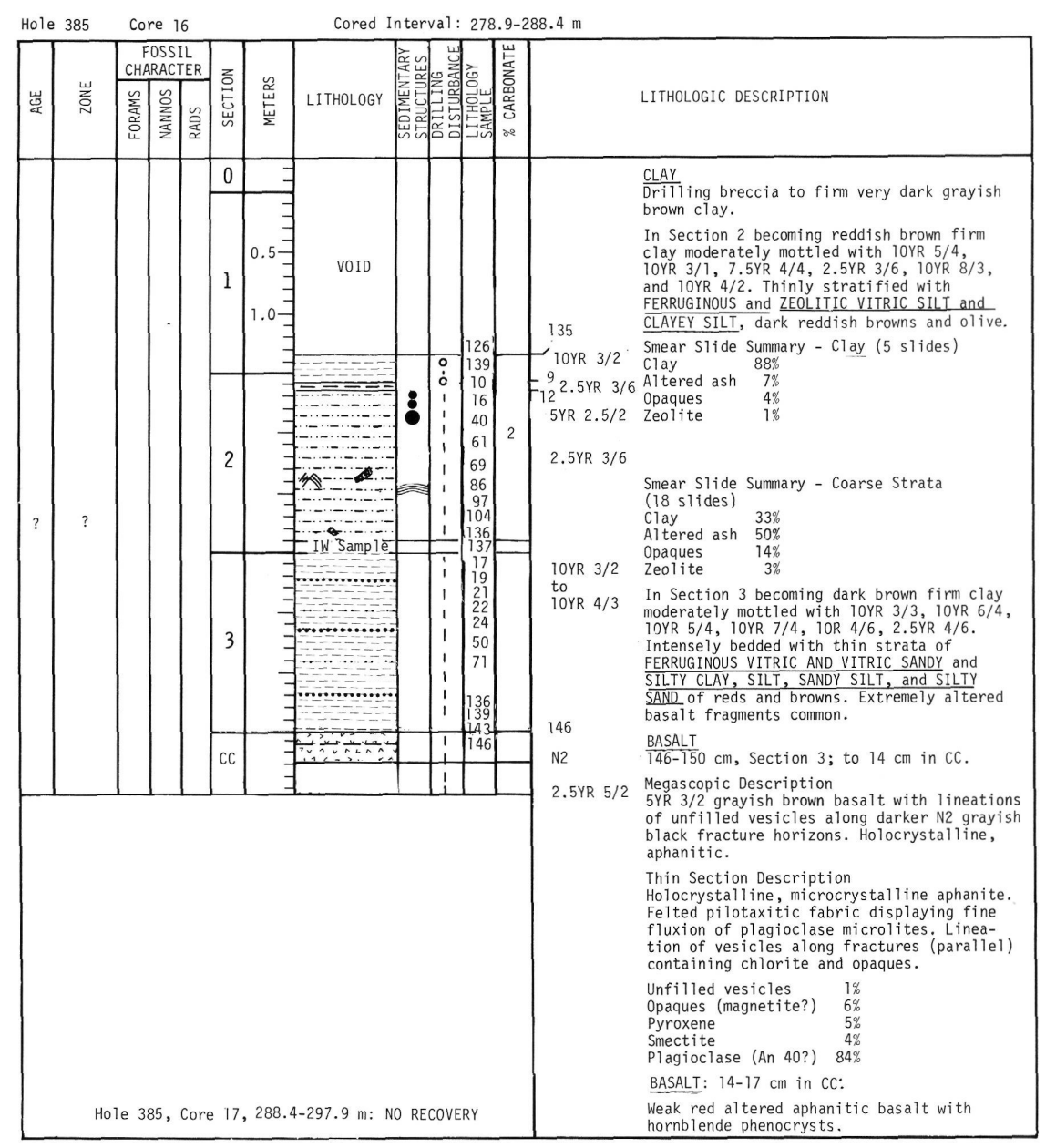

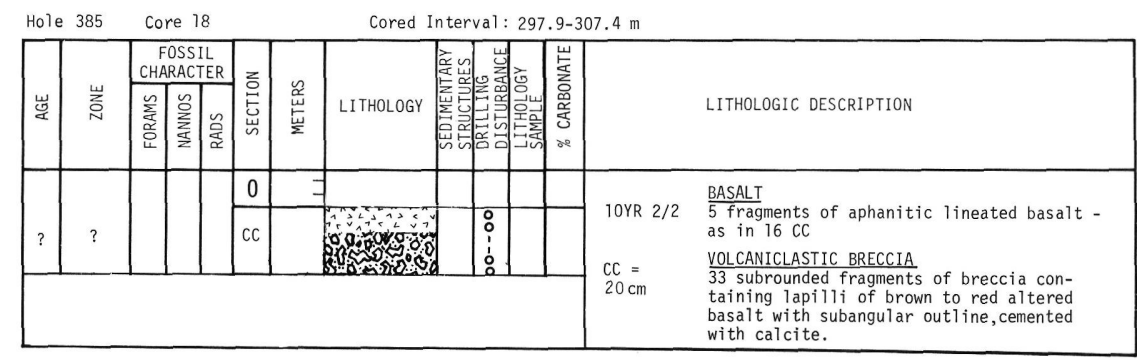




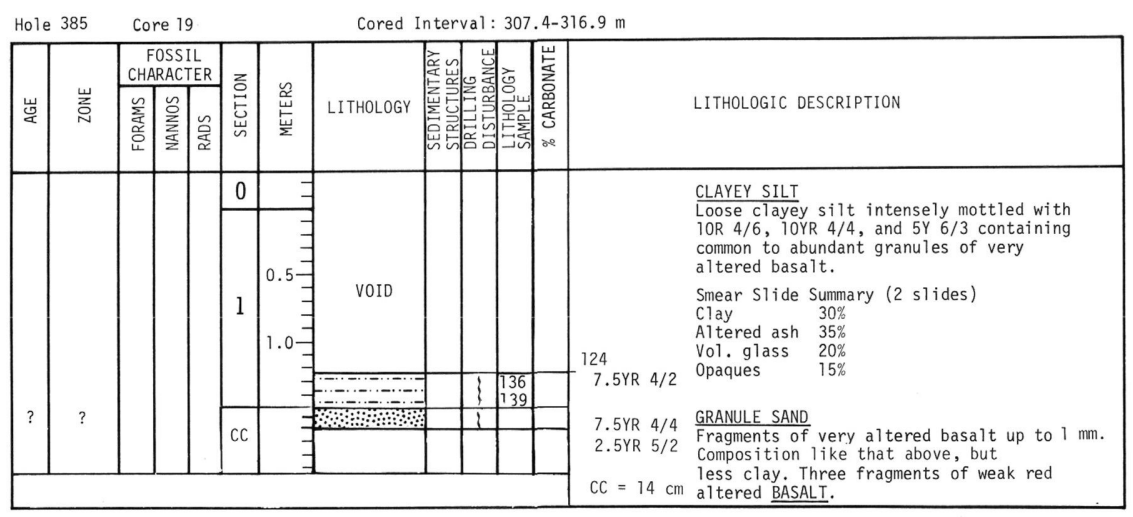

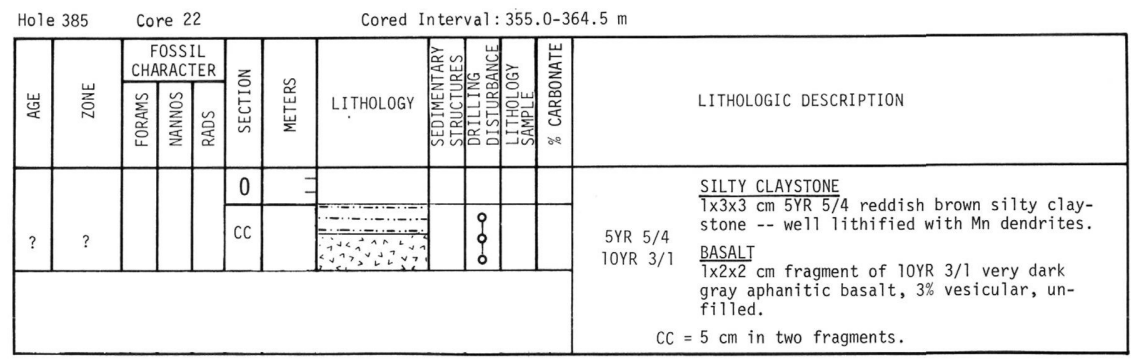
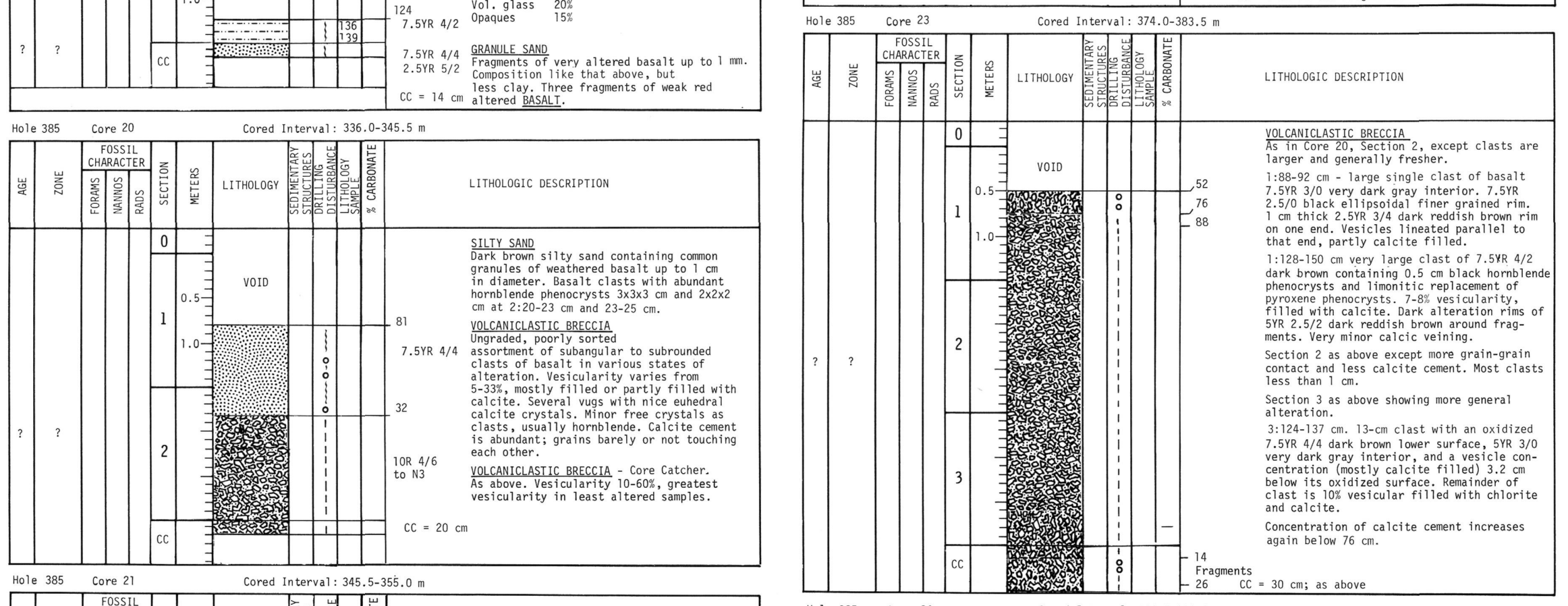

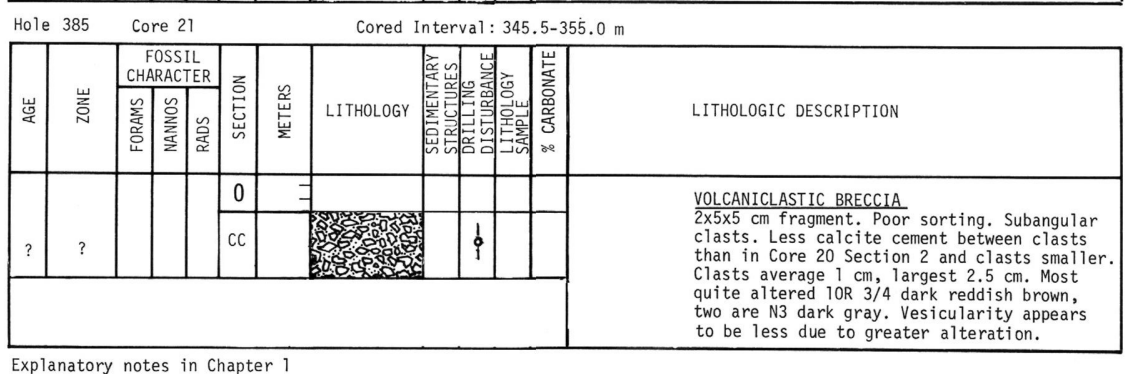

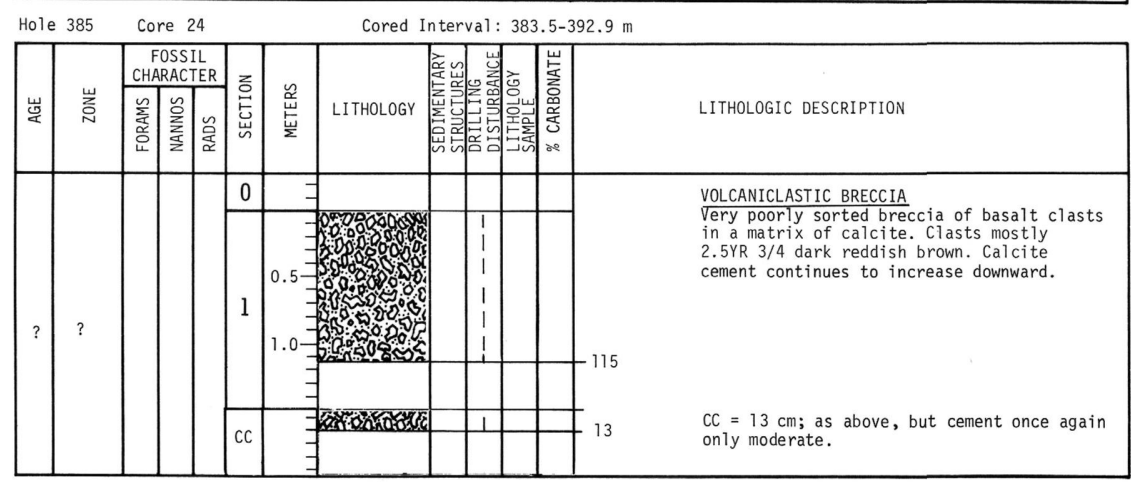









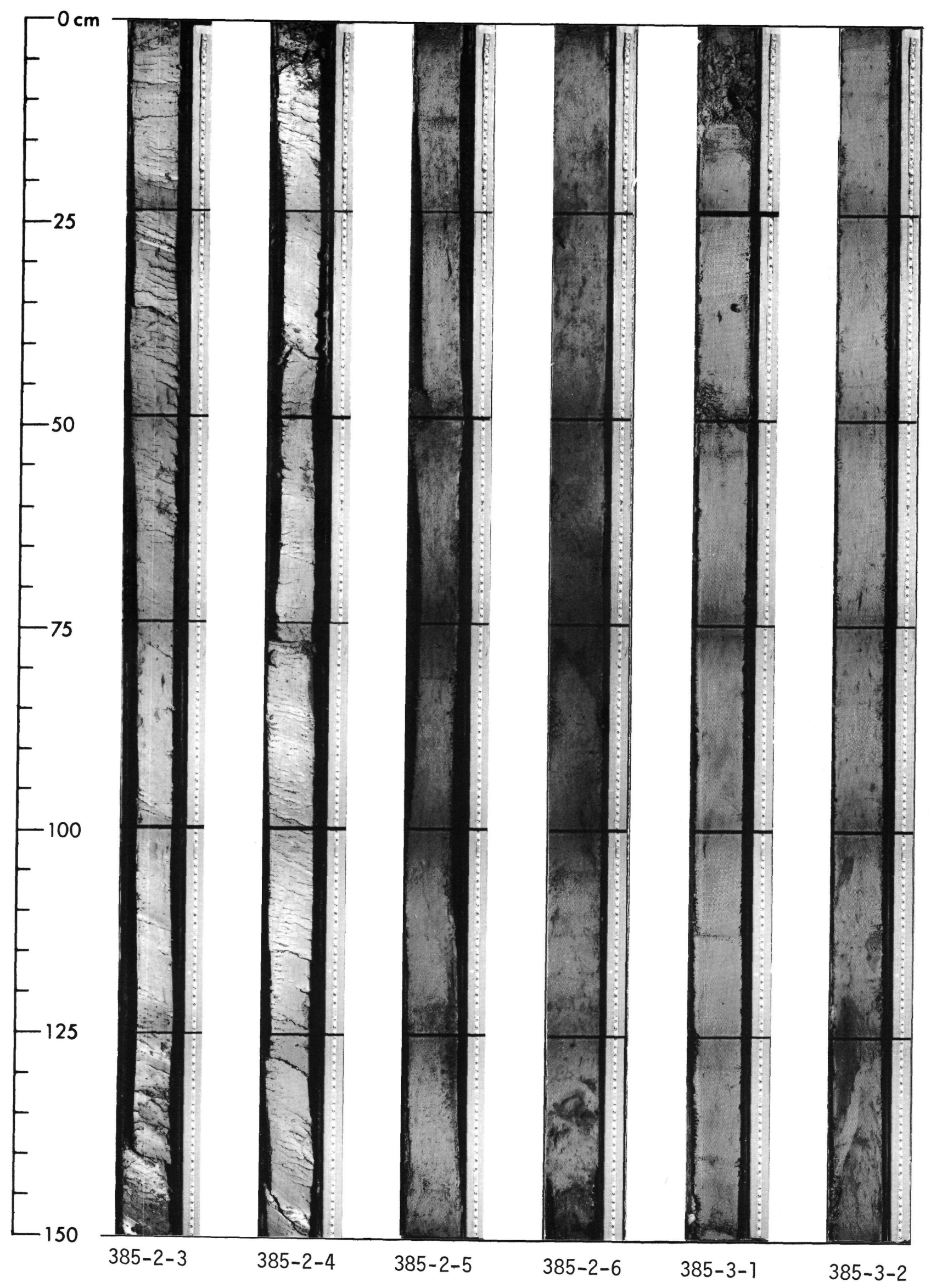




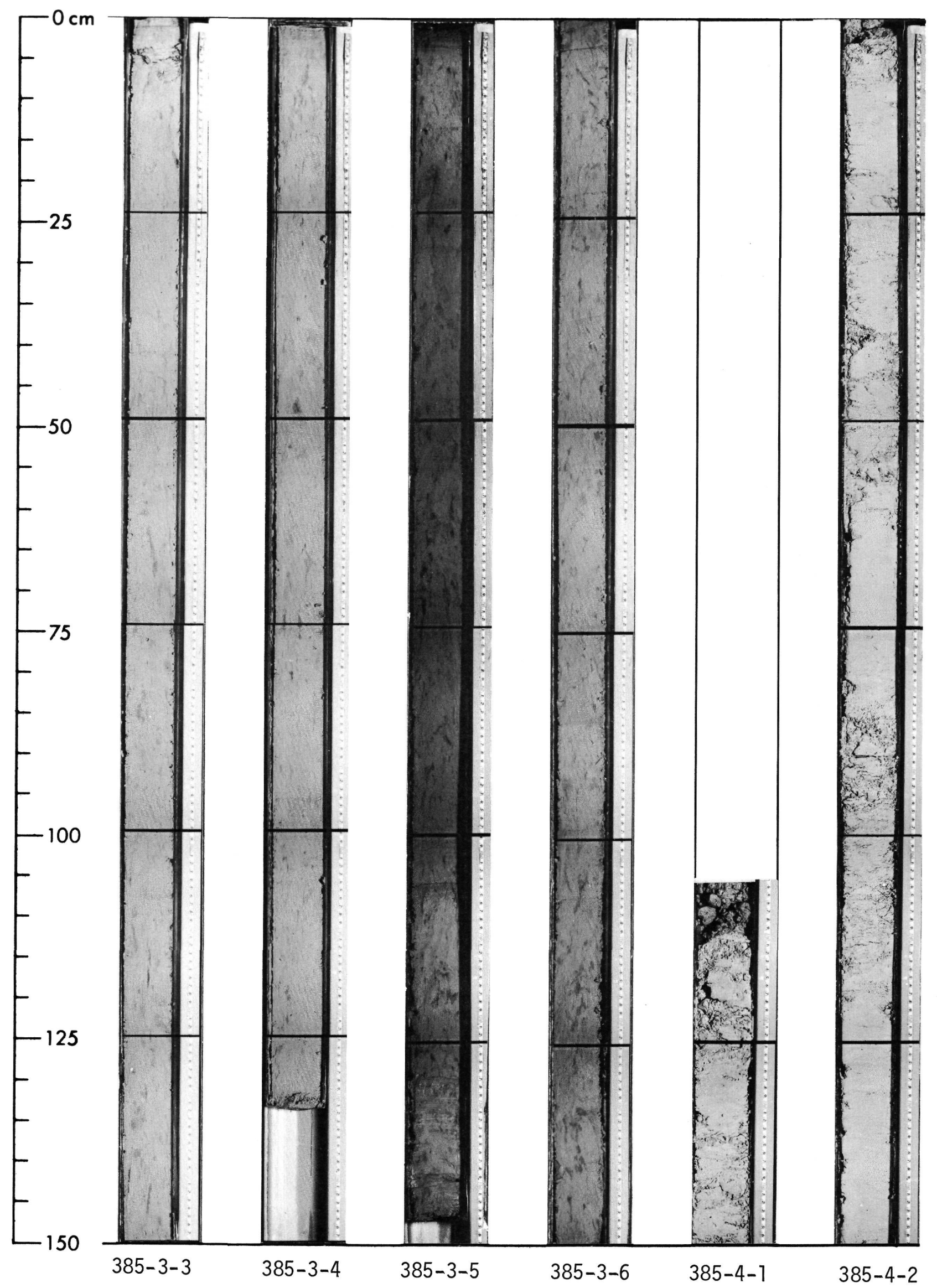




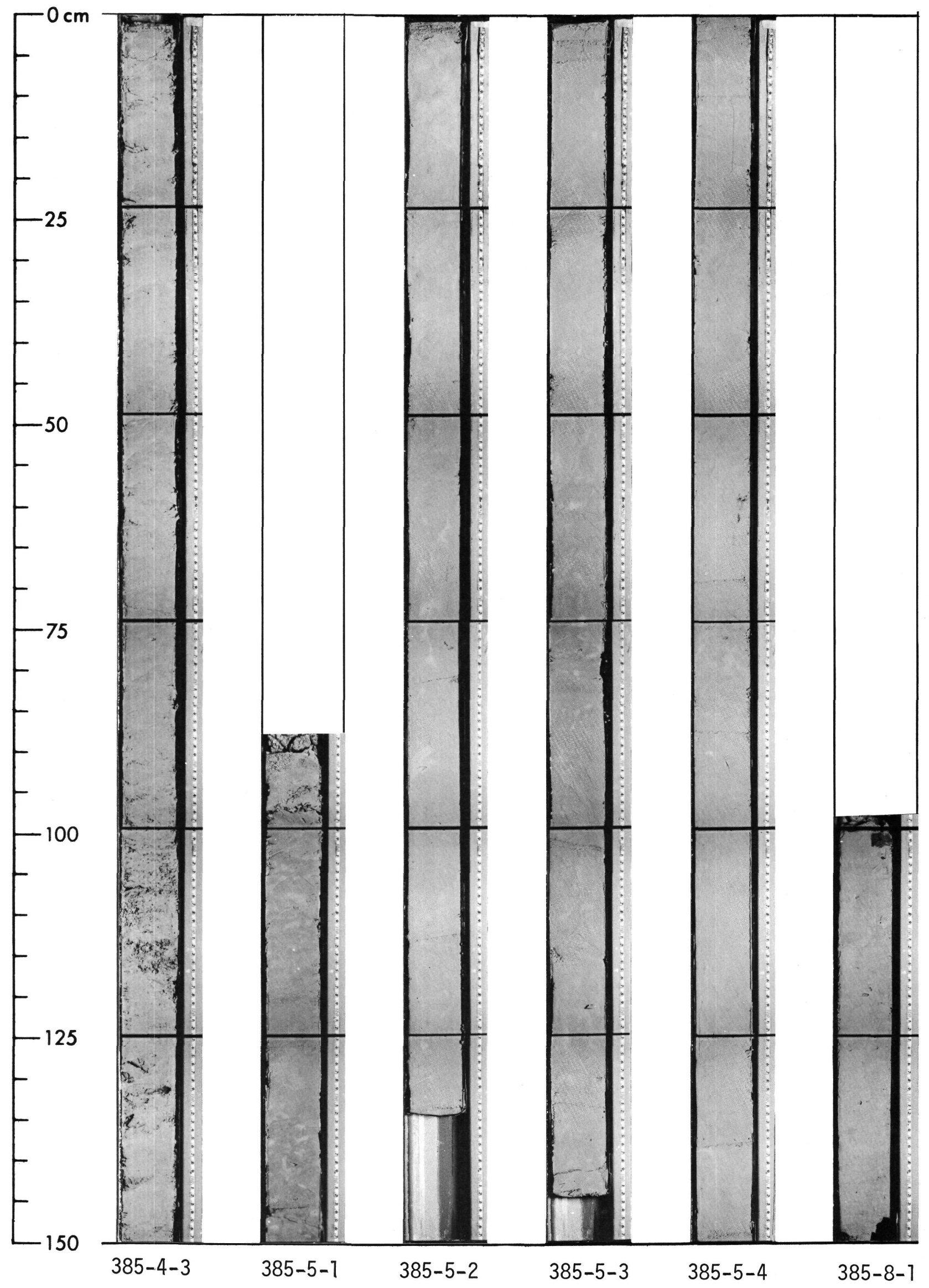




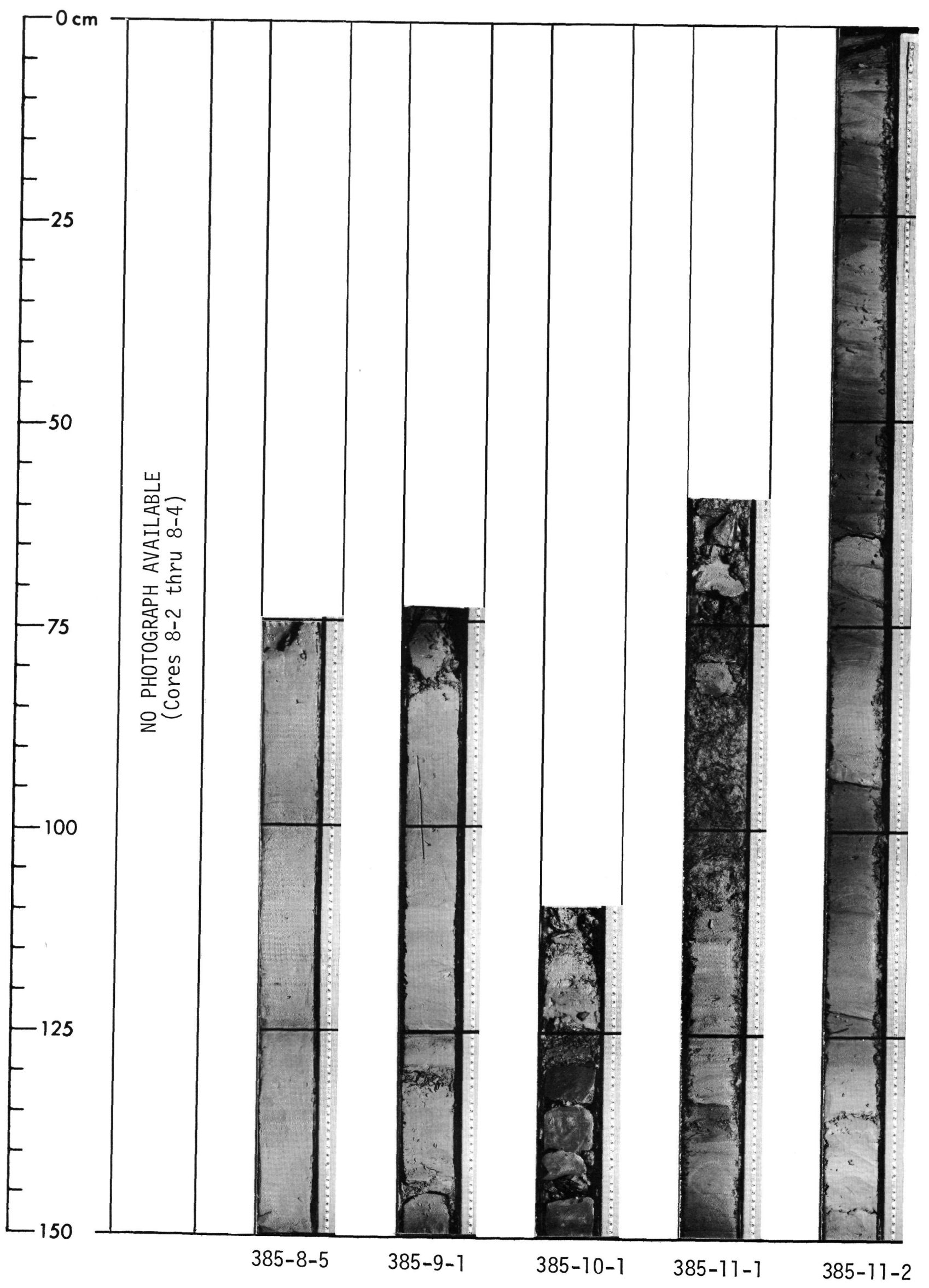




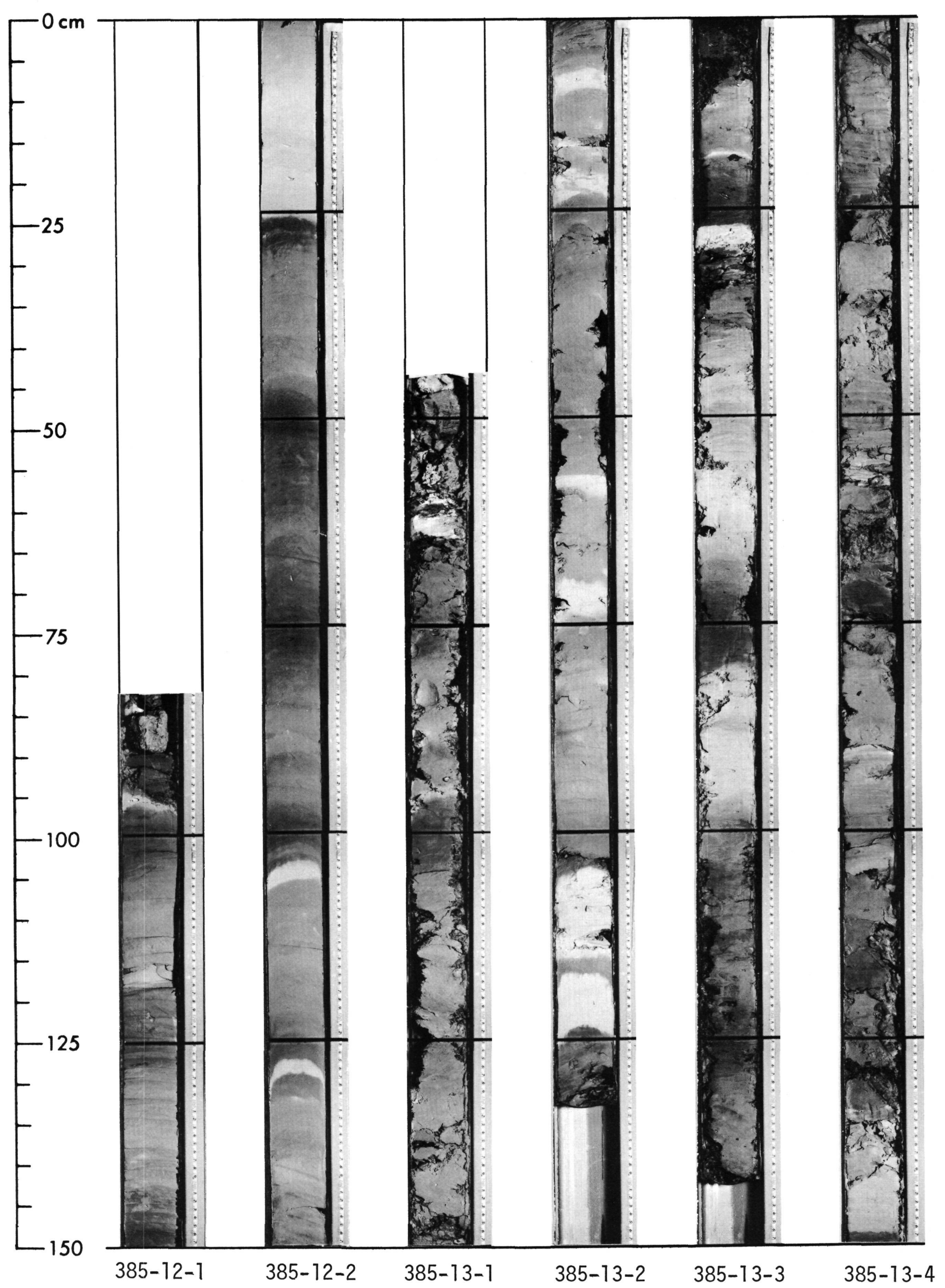




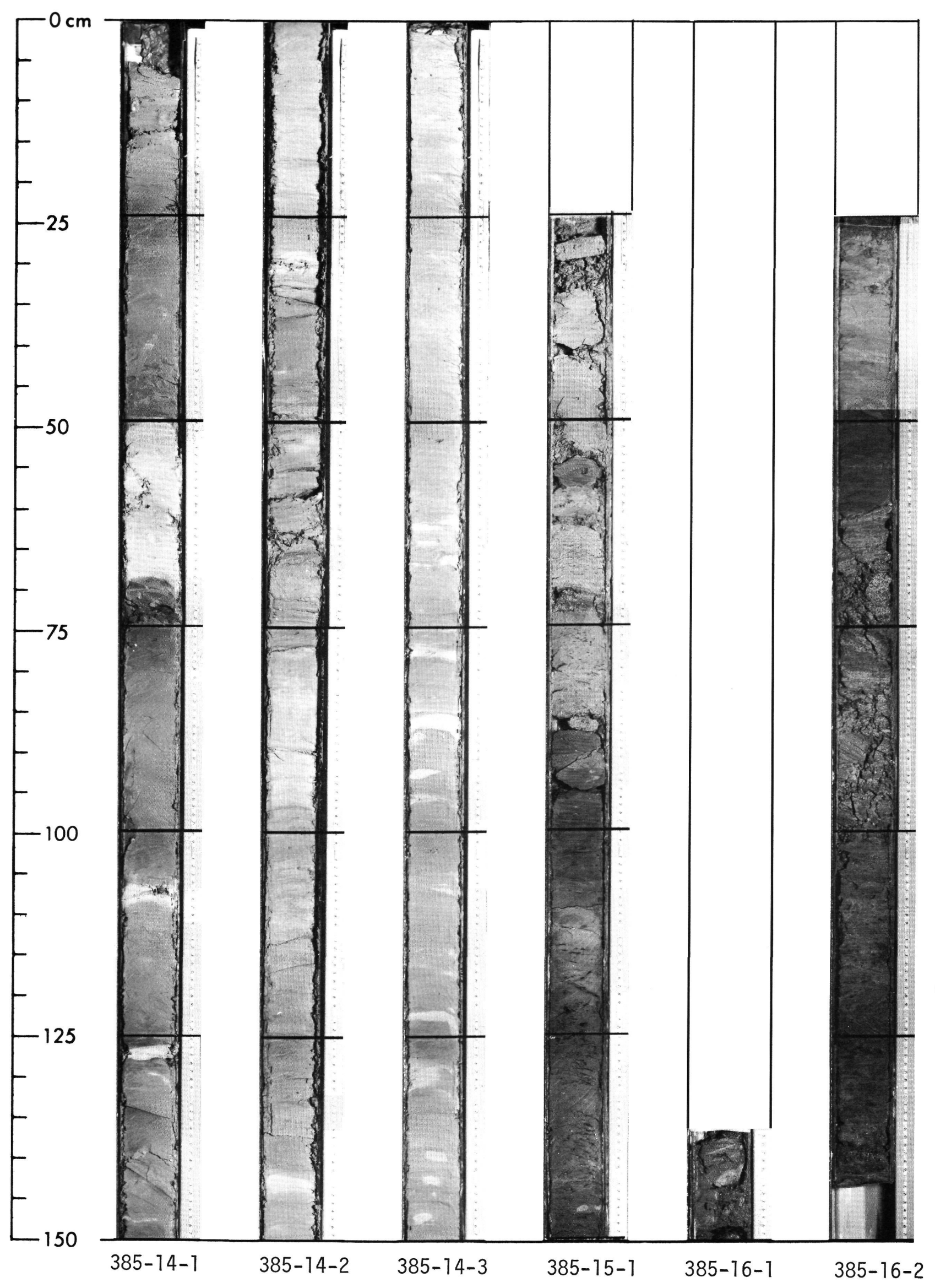




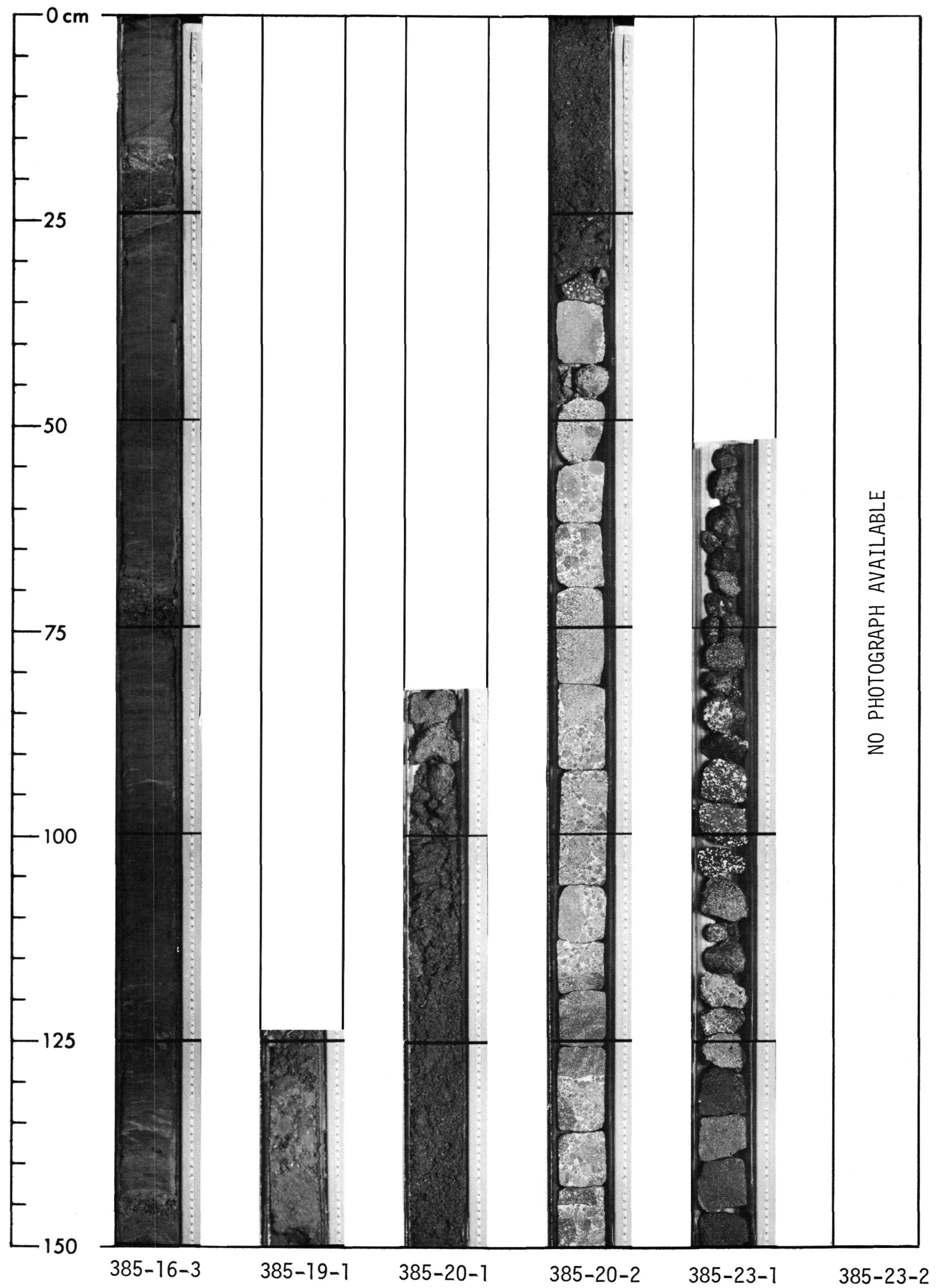






